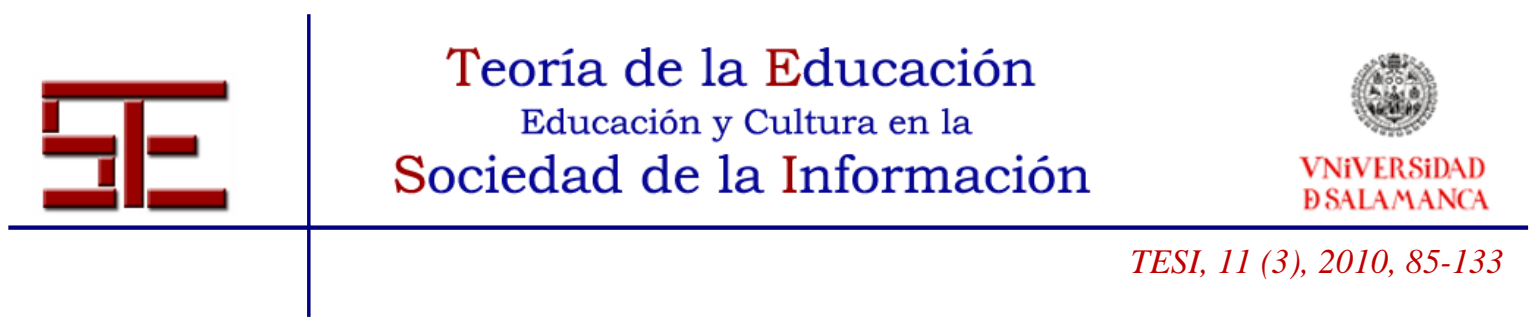

\title{
HISTORIA DE LAS PUBLICACIONES DE LOS JUEGOS DE ROL EN ESPAÑ
}

Resumen: A partir de 1985, se comenzó a publicar material relacionado con los juegos de rol en España. Desde entonces, han aparecido casi un millar y medio de libros o suplementos de rol, tanto de procedencia autóctona como traducidos de otros idiomas.

El objetivo del presente trabajo es describir la historia de los juegos de rol en España, atendiendo a los juegos publicados, a sus publicaciones y a las editoriales que han formado parte del fenómeno de los juegos de rol. Para ello, se examinó la progresión de estos elementos (juegos, publicaciones y editoriales) a lo largo del tiempo, junto a sus proporciones en cuanto a orígenes, géneros $\mathrm{u}$ otros atributos, $\mathrm{y}$ diferenciando entre aquellos elementos autóctonos (españoles) y no autóctonos, o entre distintas etapas de publicación.

Como conclusiones finales, se han sugerido una serie de predicciones acerca del posible futuro de la publicación de juegos de rol en España.

Palabras clave: Análisis descriptivo, Editoriales de rol, España, Historia de juegos de rol, Juegos de rol, Predicciones, Publicaciones de rol.

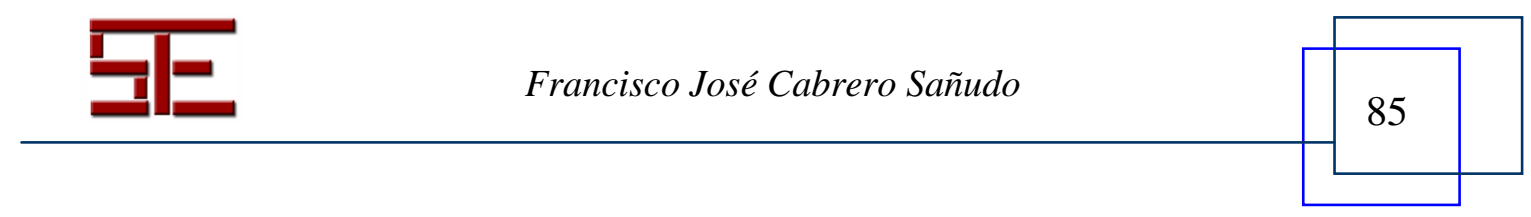




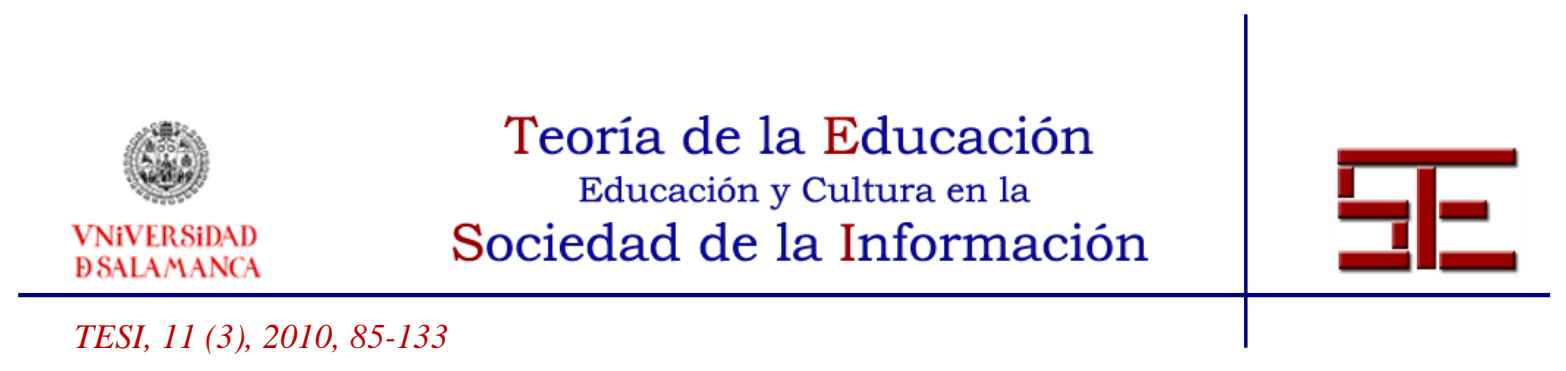

\section{PUBLICATION HISTORY OF ROLEPLAYING GAMES IN SPAIN}

Abstract: Role-playing game related products have been published in Spain since 1985. From then on, almost a thousand and a half role-playing game books or supplements have come on to the market, both of Spanish origins and translated from other languages.

The aim of the present article is to describe the history of role-playing games in Spain, attending to the published games, their publications and the publishing companies which have been part of the role-playing game phenomenon. To that end, the progression of these elements (games, publications and publishing companies) was examined throughout time, together with their proportions according to origins, genera or other attributes, and differentiating between autochthonous (Spanish) elements and not autochthonous ones, or among diverse publishing periods.

As a conclusion, a series of possible predictions about the role-playing game publication in the future in Spain have been suggested.

Key words: Descriptive analyses, Predictions, Role-playing games (RPGs), RPG history, RPG publications, RPG publishing companies, Spain.

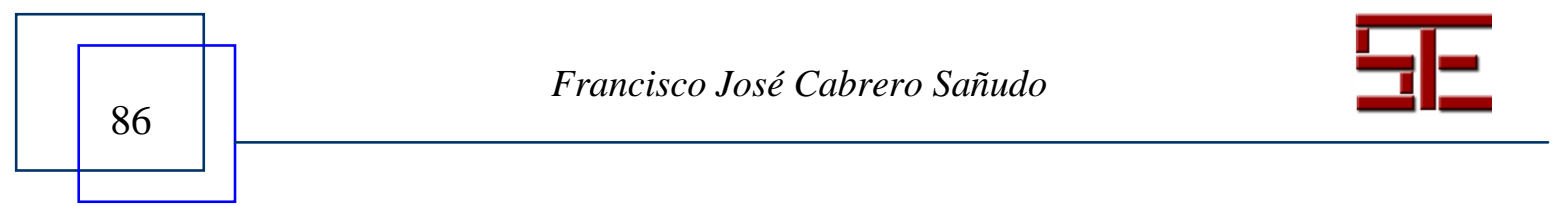




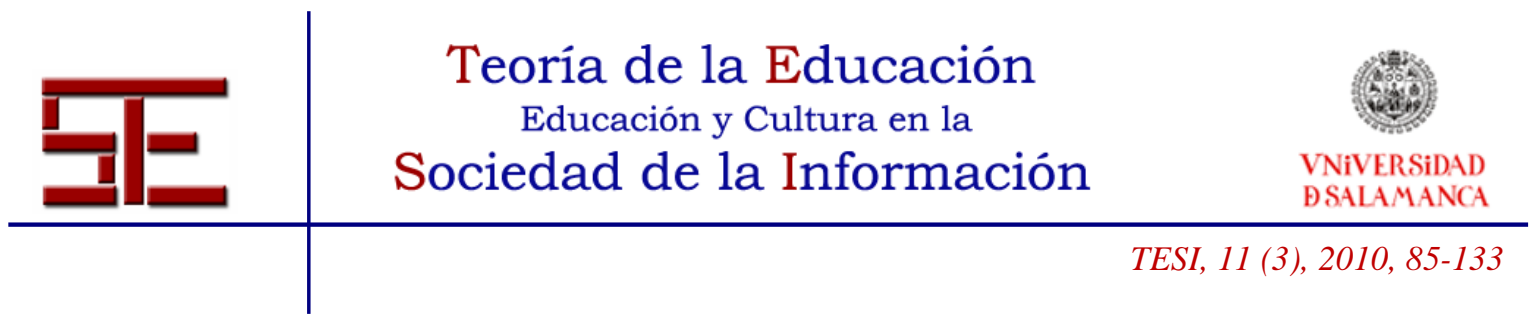

\section{HISTORIA DE LAS PUBLICACIONES DE LOS JUEGOS DE ROL EN ESPAÑA}

Fecha de recepción: 19/04/2010; fecha de aceptación: 22/09/2010; fecha de publicación: 30/11/2010

Francisco José Cabrero Sañudo

fcabrero@arrakis.es

Universidad de Alcalá de Henares, Dept. Zoología y Antropología Física.

\section{1.- INTRODUCCIÓN}

Los juegos de rol son una actividad lúdica social aparecida hace alrededor de 35 años en Estados Unidos, desde donde se han extendido hacia otros países; por ejemplo, la publicación de juegos de rol comenzó en España a partir del año 1985 y continúa en nuestros días. Son una actividad de ocio caracterizada por el hecho de que cada uno de los jugadores adopta el papel de un personaje o alter-ego y junto con el resto de compañeros jugadores construye un entorno imaginario, ejercitando el ingenio, la narración y la interpretación (ver, por ejemplo, Tizón, 2007).

Existen muchos juegos de rol diferentes, caracterizados por su género, la ambientación, el sistema de reglas utilizado para tomar decisiones, etc.; cada uno de ellos aporta elementos o puntos de vista diferentes a esta actividad de ocio. Así, unos juegos se prestarán a ser más interpretativos, otros más estratégicos y otros más narrativos (entre otras características), aunque también influya el modo y los gustos de juego de los participantes.

Esta diversidad de juegos de rol y de jugadores ha dado lugar a un desarrollo considerable de material disponible para jugar, que se ha transmitido entre los aficionados a través de publicaciones, en las que se han incluido nuevas reglas, información de trasfondo, consejos para jugadores, etc. Las diferentes editoriales que han ido surgiendo han apostado por juegos propios o ya exitosos, para proponer continuamente a los aficionados nuevos juegos o suplementos que complementen sus experiencias en este entretenimiento.

Así pues, el cometido del presente trabajo es caracterizar la historia de los juegos de rol en España, para conocer su evolución a lo largo del tiempo y predecir cómo sería un posible futuro para los mismos. Se pretende, por tanto, examinar cómo se ha

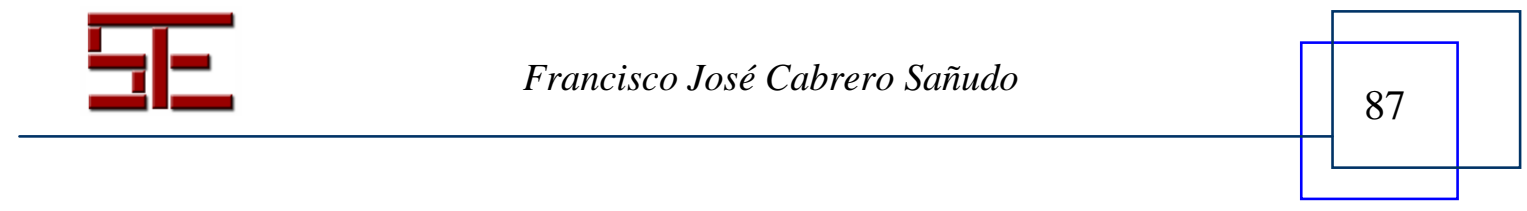




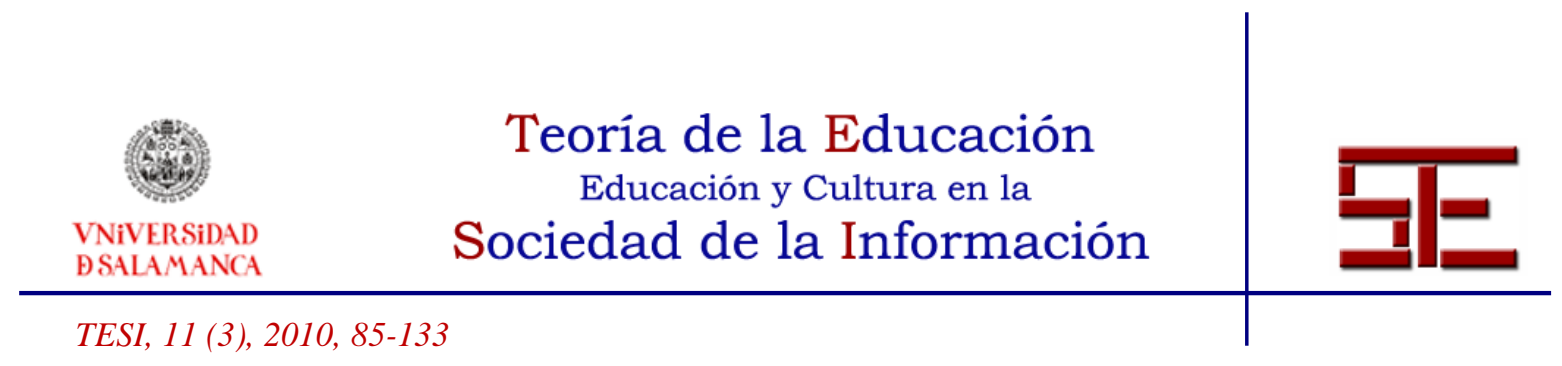

desarrollado la publicación de juegos de rol en España, atendiendo como objeto de estudio a los juegos publicados en sí, a las propias publicaciones de rol y a sus editoriales. Sencillamente, se trata de un trabajo descriptivo, acompañado, en algunos casos, de posibles explicaciones acerca de las tendencias observadas en la publicación de material relacionado con los juegos de rol.

Para poder realizar los diferentes análisis y el examen de los datos, se sobrentienden algunos supuestos: a) para examinar la historia de los juegos de rol en España sólo se tendrán en cuenta las publicaciones en idiomas españoles (castellano, gallego, catalán, etc.), aunque muchos aficionados también adquieran frecuentemente productos originales en otros idiomas; b) muchos jugadores disfrutan de juegos de rol no publicados en papel, por ser distribuidos gratuitamente (por ejemplo, por internet) o por ser de creación propia, pero estos no serán considerados en el presente trabajo; c) aunque la verdadera significación en la historia de la publicación de los juegos de rol podría estar en el tamaño de las tiradas editoriales o en la cantidad de ejemplares de una publicación concreta comprados por los aficionados, en el presente trabajo se dará sólo relevancia a los números brutos y atributos de juegos, publicaciones y editoriales que han aparecido a lo largo de la historia de los juegos de rol en España; y, d) aunque existen otras actividades educativas que utilizan los juegos de rol, sólo se han considerado para el presente trabajo aquellos juegos destinados exclusivamente a su uso lúdico.

\section{2.- MATERIAL Y MÉTODOS}

Se recopiló toda la información disponible acerca de las publicaciones de juegos de rol en España desde la aparición del primer juego en 1985 hasta 2008, considerando un intervalo total de 22 años. La información reúne todas aquellas publicaciones en papel y en idioma español, incluyendo también otras distribuidas en España y en idiomas nativos como el gallego (As crónicas de Gáidil; Fernández y Rodríguez, 2007) o el catalán (Almogàvers o Tirant lo Blanc; Grau, 1995, 1996). No se han incluido juegos de rol o accesorios disponibles en internet que no hayan sido publicados en papel; tampoco se ha incluido información sobre otros útiles que, aunque relacionados, no fueran estrictamente manuales o suplementos de rol (por ejemplo, novelas, dados o camisetas).

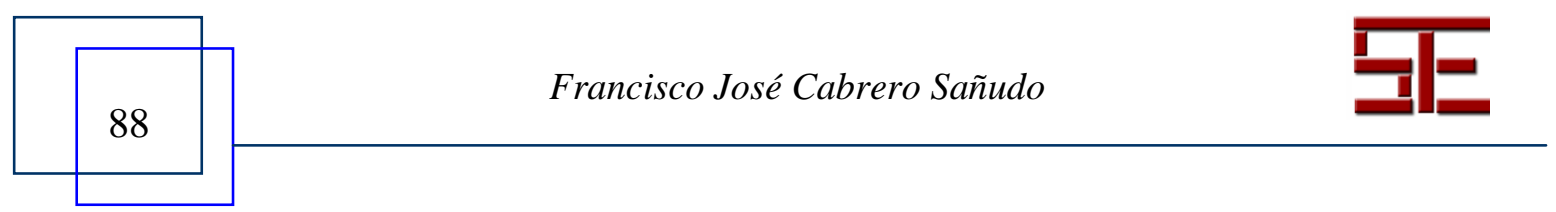




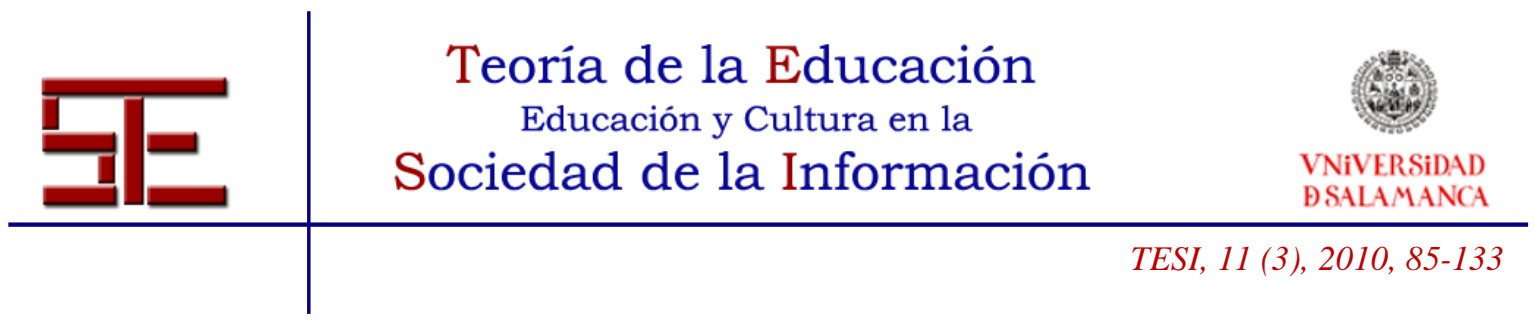

La información se ha obtenido a través de la consulta en los propios suplementos, siempre que fuera posible, y consultando a través de internet en diferentes fuentes, destacando especialmente las páginas web de BoardGameGeek (http://www.boardgamegeek.com/), PSN (http://www.psnrol.com/) y John H. Kim (http://www.darkshire.net/ jhkim/rpg/). Además, se ha intentado contrastar la información mediante la colaboración de aficionados a través de una página web dedicada a los juegos de rol, en la que se expusieron unos resultados preliminares a los del presente trabajo (Utilidades-d20; http://www.utilidades-d20.com/).

Para cada publicación se obtuvieron los siguientes datos: a) Nombre de la publicación; b) Nombre del juego al que pertenecen; c) Género del suplemento (éste puede en algunos casos variar con respecto al del juego o al de otros complementos del juego, por ejemplo, cuando se trata de un juego multigenérico); d) Nacionalidad de origen del suplemento (ésta puede variar en algunos casos con respecto a la del juego, por ejemplo, cuando se trata de algún suplemento escrito en España para un juego traducido); e) Editorial que publica el suplemento; y, f) Año de publicación.

A partir de estos datos, se obtuvo también la información sobre cada juego de rol, como: a) Nombre del juego de rol; b) Género del juego; c) Nacionalidad de origen del juego; d) Editorial/es que publica/n el juego; y, e) Años en los que hubo publicaciones de este juego. Se han considerado como un mismo juego aquellas ediciones en las que no se dieran cambios significativos en las reglas como para crear alguna incompatibilidad de uso entre sí.

Así mismo, se extrajo la información sobre las editoriales, en particular: a) Nombre de la editorial; b) Años de publicación de los suplementos autóctonos y no autóctonos; c) Número de juegos autóctonos y no autóctonos para los que han publicado suplementos; y, d) Nacionalidad de origen de la editorial.

Con respecto a los géneros, se han considerado un total de 14 categorías, basadas libremente en la clasificación de Schmidt (2005). Se ha asignado únicamente una categoría a cada juego o género, de modo que cuando alguno de estos perteneciera a géneros diferentes se ha procurado tomar aquel que representara mejor la esencia de la ambientación. Las categorías de los géneros son las siguientes: acción, bélico, cienciaficción (incluyendo también ciencia-ficción fantástica), erótico, fantasía, historia (incluyendo también historia fantástica), humor, misterio, oeste, policíaco, superhéroes y terror. Existen también dos categorías especiales que son las de multigenérico, si la

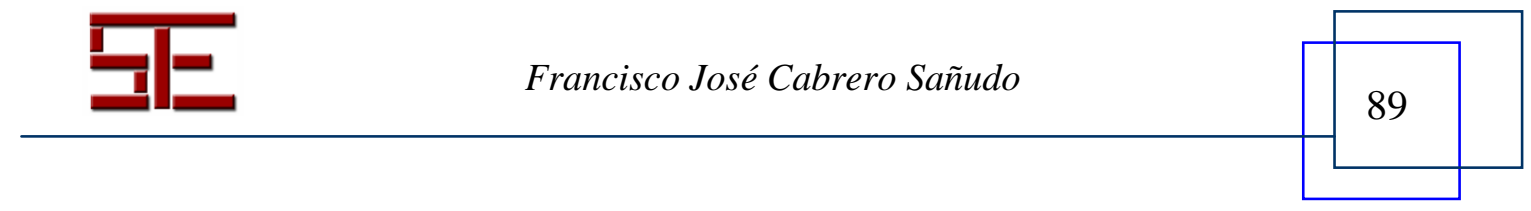




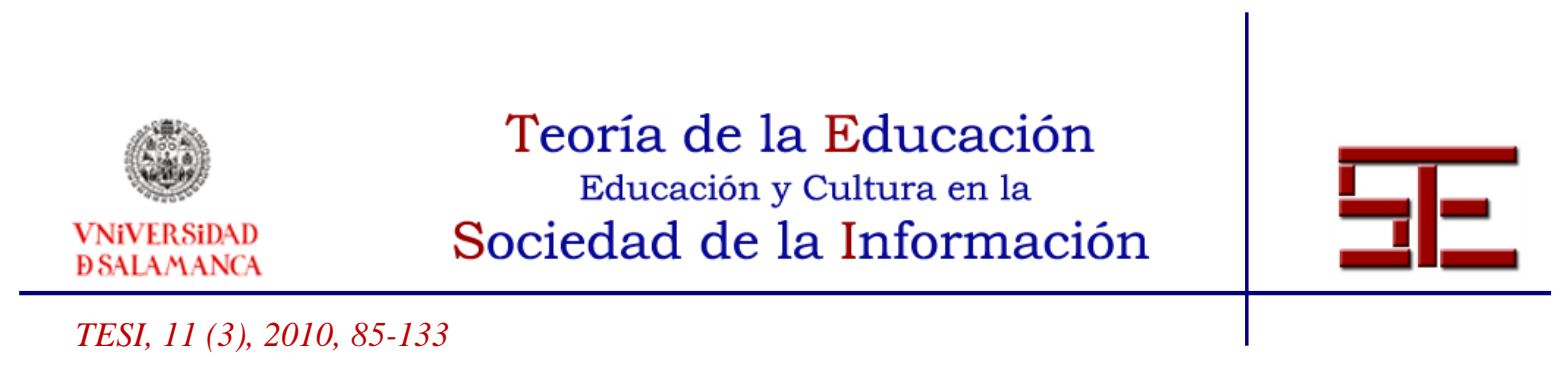

publicación o juego permite varios géneros, y rol en vivo (independientemente de su género), si se trata de esta variación de juego de rol.

Teniendo en cuenta los objetos de estudio (juegos, publicaciones o editoriales), se realizaron tres conjuntos diferentes de análisis. Para cada conjunto de análisis, se examinó su progresión a lo largo del tiempo, así como las proporciones en cuanto a orígenes, géneros u otros atributos, según correspondiera al objeto de estudio $\mathrm{y}$, cuando fuera posible, diferenciando entre aquellos elementos autóctonos (españoles) y no autóctonos (de otra nacionalidad), o entre elementos de una primera etapa (E1; los primeros once años del intervalo, 1985-1996) y de una segunda etapa (E2; los siguientes once años, 1997-2008). Esta última diferenciación en dos etapas del período de aparición de publicaciones de juegos de rol ha sido seleccionada en base a los resultados de un análisis de estimación no lineal Piecewise lineal regression realizado con la curva de publicaciones totales acumuladas a lo largo del tiempo; este análisis descubrió dos funciones lineales (tendencias) diferentes en una curva, correspondientes a dos pendientes (o, en este caso, tasas de publicación) distintas en la historia de publicaciones de rol en España ( $\mathrm{p}<0.05$; R2=98.84\%).

Todos los análisis y las gráficas fueron realizados mediante los programas Excel 2007 (Microsoft Corporation, 2007) y Statistica 7.1 (StatSoft Inc., 2006).

\section{3.- RESULTADOS Y DISCUSIÓN}

\section{1.- Juegos de rol publicados en España}

\subsection{1.- Progresión de los juegos de rol publicados en España}

El número total de juegos de rol diferentes publicados en España desde 1985 a 2008 es de 174, siendo alrededor del 40\% (72) autóctonos y del 60\% (102) no autóctonos (Tabla 1). Teniendo en cuenta las dos etapas diferenciadas, aparecieron alrededor de un $30 \%$ (53) de los juegos en E1 y de un 70\% (121) en E2, aunque en esta última etapa se realizaron publicaciones para el 85\% (146) de los juegos disponibles (Tabla 1). Como se puede apreciar, en E2 aparecieron más del doble de juegos que en E1; esta relación entre etapas difiere según el origen de los juegos, ya que, con respecto a los juegos autóctonos, la diferencia supera el triple de juegos (17 en E1 frente a 55 en E2),

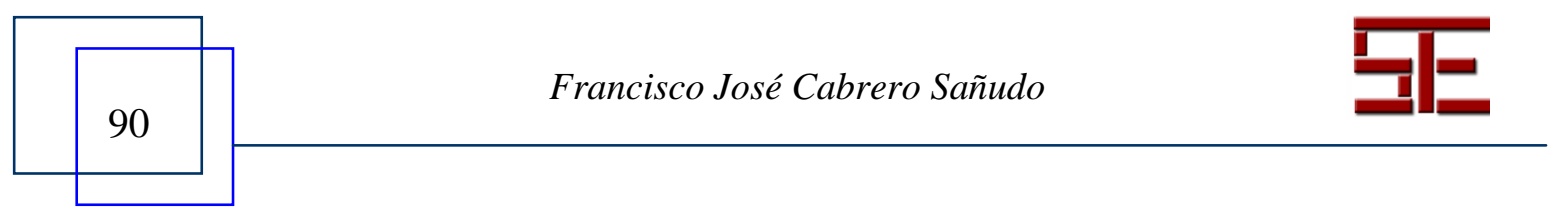




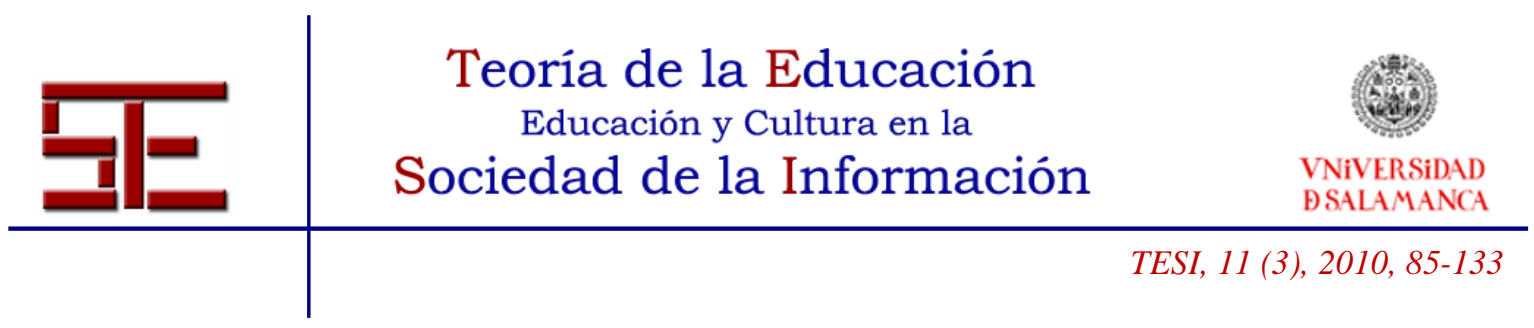

mientras que en los juegos no autóctonos es ligeramente inferior al doble (36 en E1 frente a 66 en E2; Tabla 1).

En la Tabla 2 se observa que, globalmente, se han publicado una media de alrededor de siete juegos nuevos de rol al año, de los cuales tres han sido autóctonos y cuatro no autóctonos. Más concretamente, en E1 se han publicado poco más de 4 juegos por año, mientras que en E2 esta cifra se duplica a más de 10 (Tabla 2). La media de aparición por año de juegos autóctonos con respecto a no autóctonos ha pasado de ser la mitad de ésta a casi equipararse a ella (de 1.42 frente a 3.00 juegos por año en E1, a 4.58 frente a 5.50 en E2, de autóctonos y no autóctonos, respectivamente). Este crecimiento se aprecia también en la Figura 1, donde se observa que durante E1 la curva de juegos no autóctonos siempre supera o iguala a la de juegos autóctonos, mientras que en E2 la curva de autóctonos se equipara más a la de no autóctonos. Además, el número de juegos autóctonos parece seguir creciendo progresivamente, mientras que la aparición de juegos no autóctonos es cada vez más pausada (la curva de juegos autóctonos tiene una mayor pendiente que la de no autóctonos, la cual parece tender hacia una asíntota; Figura 2).

Aunque los juegos de rol surgieron en Estados Unidos en 1974 con la aparición del juego Dungeons \& Dragons (Gygax y Arneson, 1974) y muchos aficionados españoles pudieran haber descubierto desde entonces los juegos de rol a través de libros en otros idiomas, no fue hasta once años más tarde cuando comenzaron a publicarse en España, con la primera publicación de rol, popularmente conocida como la caja roja, para el juego Dungeons \& Dragons Básico (Gygax et al., 1985; Figura 3). A partir de ese momento, el fenómeno de los juegos de rol comenzó tímidamente a popularizarse, dando lugar primero a traducciones de juegos que ya llevaban varios años existiendo en otros países (como Runequest [Stafford, 1988], La Llamada de Cthulhu [Petersen, 1988], Traveller [Miller, 1989] o El Señor de los Anillos - MERP [Charlton, 1989]) y, posteriormente, a juegos autóctonos (Figura 3). Estos juegos autóctonos comenzaron a aparecer cinco años más tarde con el juego Sistema Ambivalente Multitemporal (SAM; Caselles, 1990), seguido por Aquelarre (Ibáñez, 1990) y Comandos de Guerra (Herreros, 1990; Figura 3).

Desde entonces y durante el resto de E1, la aparición de nuevos juegos de rol es progresiva, más constante en los juegos autóctonos que en los no autóctonos (Figura 1). No obstante, durante los primeros años de E2 (1997-2000), se produce una recesión en la publicación de nuevos juegos de rol (Figura 2); se han sugerido diversas causas de

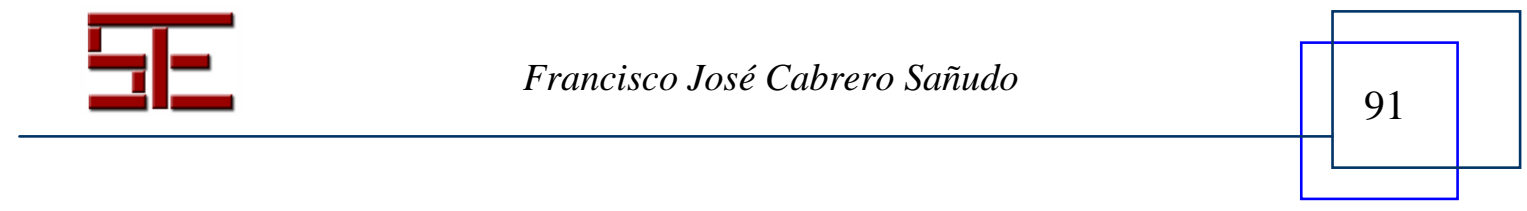




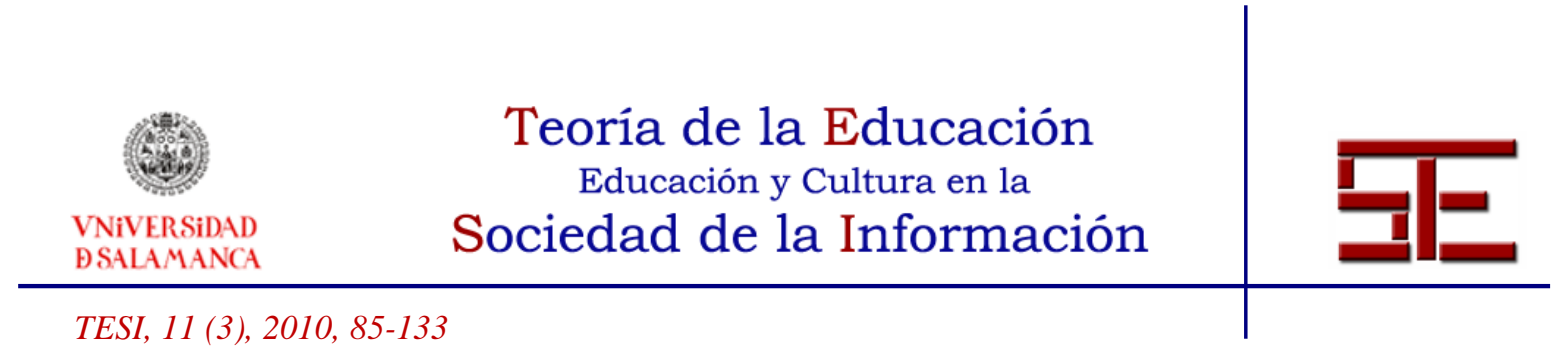

ésta, entre las que destacan la mala prensa hacia los juegos de rol por parte de medios de comunicación y cine (Sánchez, 2007) o la aparición de otro tipo de juegos en el mercado, como los de cartas coleccionables. Posteriormente, a partir de 2001, el número de juegos de rol aumentó (especialmente, en 2002) y, aunque se han publicado menos juegos autóctonos que no autóctonos (Figuras 1,2), el número de autóctonos ha ido superando los años de desventaja frente a los no autóctonos y aumenta paulatinamente en España a una mayor velocidad que estos (Figura 2), incluso superándolos notablemente en número en 2008 (Figura 1). No se ha especulado a qué se ha debido esta reactivación en la aparición de nuevos juegos en los últimos años; es posible que pueda haberse debido, entre otras causas, a una reacción de los aficionados frente a la crisis anterior (caracterizada, en cierto modo, por el hecho de que muchos de ellos querían aportar su contribución o experimentar buscando romper las reglas tradicionales de los juegos de rol), a la aparición de sistemas de juego de licencia libre que popularmente han tenido gran aceptación y han favorecido el mercado, siendo utilizados por diversas editoriales o, simplemente, autores independientes (como, el Sistema-d20; Wizards of the Coast Inc., 2000), o a una cierta facilidad para realizar autopublicaciones mediante empresas que ofrecen sus servicios a través de internet y según la demanda existente (así, se han producido hasta 20 autopublicaciones en los últimos años de E2, correspondientes a 8 juegos nuevos).

En cuanto a la vida media de los juegos de rol, en general un juego presenta publicaciones durante casi cuatro años, siendo menor esta vida media en los juegos autóctonos (alrededor de 2.5 años) que en los no autóctonos (más de cuatro años; Tabla 2), lo que probablemente se debe, por una parte, a un tardío despegue en la publicación de material autóctono frente al traducido y, por otra parte, al material disponible para los juegos no autóctonos, puesto que no dependen únicamente del mercado español. El juego que durante más años ha sido publicado en España es La llamada de Cthulhu (Petersen, 1988), que ha sido traducido a un ritmo constante al menos por tres editoriales. Otro de los juegos con mayor vida de publicación es el autóctono Comandos de guerra (Herreros, 1990), aunque ha sufrido largos períodos sin publicaciones. El juego de El Señor de los Anillos - MERP (Charlton, 1989) es el tercer juego más duradero en publicación, seguido por Aquelarre (Ibáñez, 1990). Como se puede observar, son juegos de entre los primeros publicados en España (Figura 3). No obstante, muchos otros juegos, pese a tener una larga vida y seguir activos fuera de España, han dejado de ser traducidos, como es el caso, por ejemplo, de Ars Magica (Tweet y Rein•Hagen, 1993), Shadowrun (Dowd, 1993) o Cyberpunk (Pondsmith,

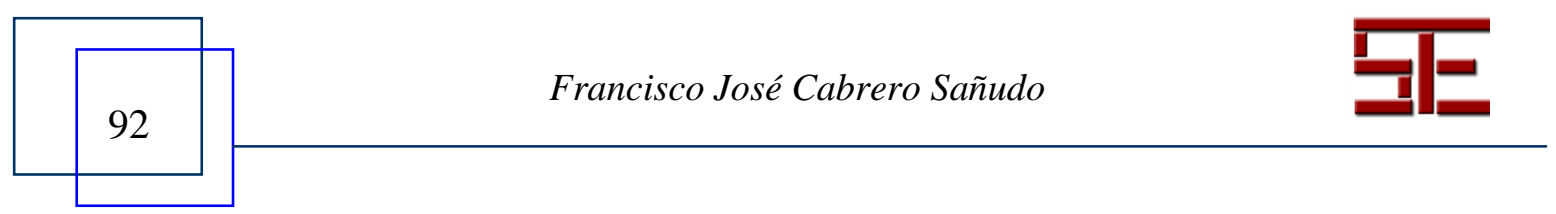




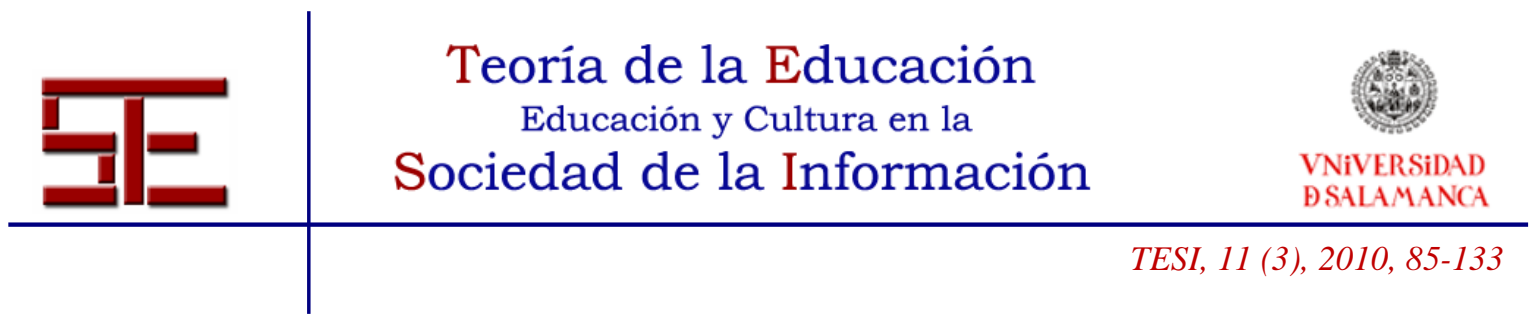

1993). Habrá que esperar para presenciar qué sucede con juegos que continúan siendo publicados actualmente y que han sido publicados más tarde.

Existen también líneas de juegos que comenzaron en E1 a partir de un juego con un sistema, una ambientación o un nombre propio y que han dado lugar posteriormente a diversos nuevos juegos dentro de dicha línea, continuándose ésta en E2 a lo largo de un amplio período de publicación; éste es el caso, por ejemplo, de la línea de Mundo de Tinieblas (con juegos como, por ejemplo, Vampiro, la mascarada [Rein•Hagen, 1993], Hombre lobo, el apocalipsis [Rein•Hagen, 1995], Mago, la ascensión [Wieck et al., 1996] o el nuevo Mundo de Tinieblas [Bridges et al., 2004]) o la línea de Dungeons \& Dragons (con juegos como D\&D Básico [Gygax et al., 1985], Advanced D\&D $2^{\mathrm{a}}$ Ed. [Cook, 1992], D\&D 3/3.5 Eds. [Cook et al., 2001, 2003] o D\&D 4ª Ed. [Heinsoo et al., 2008]).

\subsection{2.- Origen de los juegos de rol publicados en España}

Como se observó en la Tabla 1, más de la mitad de los juegos publicados en España no son autóctonos (Figura 4). La gran mayoría de los juegos no autóctonos procede de Estados Unidos (78 juegos, alrededor del $45 \%$ del total; Figura 4). Otra pequeña parte de los juegos no autóctonos tiene su origen en el Reino Unido (10 juegos, alrededor del $6 \%$ del total; Figura 4). Las demás procedencias no autóctonas (14 juegos, alrededor del 8\%) son relativamente anecdóticas y variadas: Canadá, Francia, Polonia, Suecia, México y Alemania. Según continentes, alrededor de la mitad de los juegos publicados en España son de origen europeo (90 juegos, alrededor del 52\%), mientras que la otra mitad es de origen norteamericano (84 juegos, alrededor del $48 \%$ ).

Según etapas, en E1 más de dos terceras partes del total de juegos (36) no eran autóctonos, teniendo origen estadounidense alrededor del 60\% del total (32) y habiendo también una pequeña representación de juegos franceses y suecos (Figura 5). No obstante, en E2 la aportación autóctona pasa del 33\% al 45\% del total (55 juegos), no superando al porcentaje de juegos no autóctonos, pero sí a los de origen estadounidense (46 juegos, 38\% del total). El porcentaje de juegos con otras procedencias que no fueran la española o la estadounidense se duplica desde menos de un $8 \%$ en E1 a casi un $17 \%$ del total en E2 (Figura 6).

Así pues, en una primera etapa se mira especialmente a Estados Unidos, país en el que surgen los juegos de rol y donde se produce un gran desarrollo de estos; sin embargo,

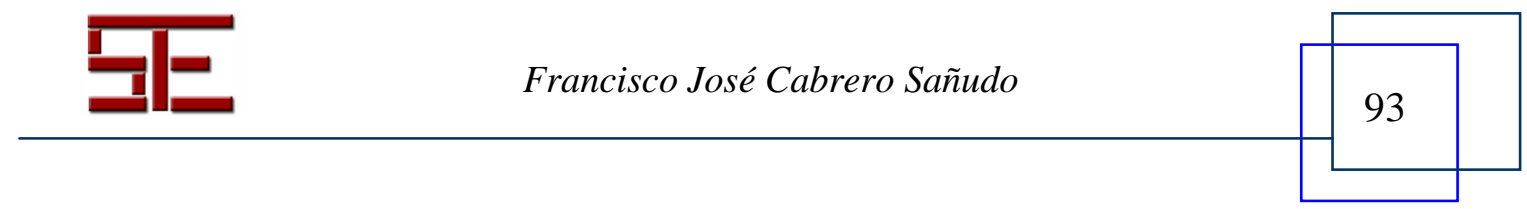




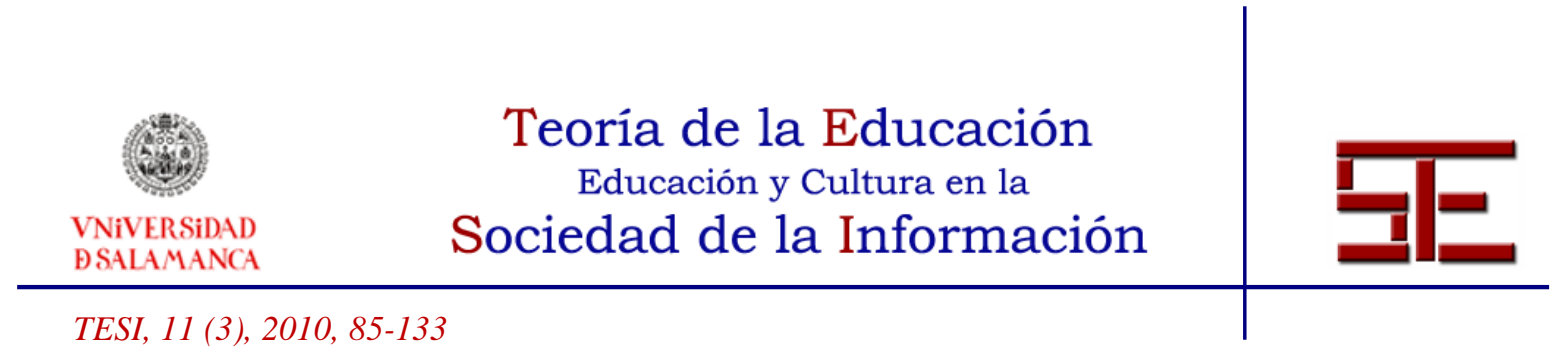

más adelante, se han desarrollado juegos de rol en otros países y se ha comenzado a valorar progresivamente la creación de juegos en España, de modo que la diversidad de orígenes ha aumentado, así como el número de juegos autóctonos. No obstante, el porcentaje de juegos con origen estadounidense sigue siendo bastante importante.

\subsection{3.- Género de los juegos de rol publicados en España}

El género de rol más popular de entre los publicados en España es el de fantasía (50 juegos, 29\% del total; Figura 7); este género inició el fenómeno de los juegos de rol y pronto estos se extendieron hacia los demás géneros. Junto con el género de terror (con 34 juegos) la fantasía se encuentra presente en casi el 50\% de los juegos publicados. Los géneros de ciencia-ficción y humor también presentan una proporción considerable (entre los dos, 44 juegos, que representan más de un 25\% del total). Los juegos de rol multigenéricos y los de historia se encuentran representados conjuntamente en alrededor de un 13\% del total (23 juegos). Otro $13 \%$ del total (23 juegos) corresponde a los demás géneros de juegos de rol (acción, rol en vivo, superhéroes, oeste, bélico, erótico, misterio o policíaco), muchos de ellos clasificaciones más especializadas de los anteriores géneros (por ejemplo, el género de superhéroes podría ser considerado como una subdivisión del de ciencia-ficción, mientras que el del oeste podría serlo del de historia). Se debe destacar el hecho de que los géneros más comunes son los considerados tradicionalmente más imaginativos (fantasía, terror y ciencia-ficción). Es también notable que, frente al estilo tradicional de juegos de rol, los juegos de rol en vivo sólo se encuentran presentes en alrededor de un 3\% del total (5 juegos; Figura 7).

Por otra parte, si se examinan los géneros de los juegos autóctonos publicados en España (Figura 8) se observa que existe una gran diferencia entre estos y los de los juegos no autóctonos (Figura 9). En el primer caso, los juegos de fantasía constituyen únicamente poco menos de un 20\% (14 juegos) del total de los autóctonos y los de terror y ciencia-ficción sólo están representados conjuntamente en alrededor de un $18 \%$ (13 juegos entre los dos; Figura 8). Sin embargo, el género más frecuente entre los autóctonos es el de humor (15 juegos, alrededor del $21 \%$ del total) y el de historia por sí solo está presente en el 14\% de los juegos (10 juegos). En comparación con los juegos no autóctonos publicados en España, destacan también los juegos multigenéricos (6 juegos, $8 \%$ del total) y la variedad de géneros (14 géneros diferentes en total frente a 10 de los no autóctonos).

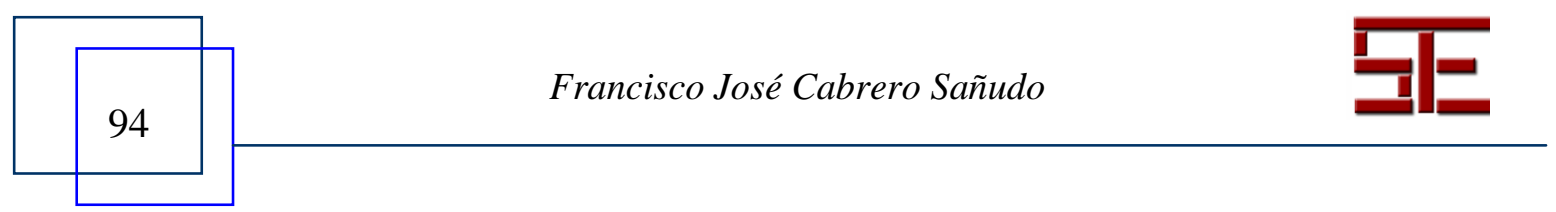




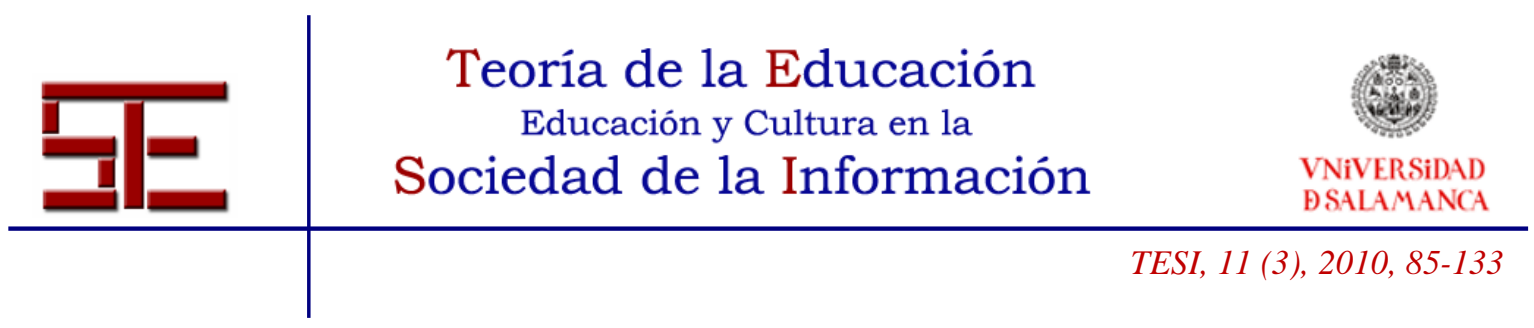

En cuanto a los juegos no autóctonos publicados en España, se observa que más de una tercera parte de estos es de género fantástico (Figura 9) y que se encuentran bien representados los géneros de terror y ciencia-ficción (28 y 18 juegos, respectivamente; conjuntamente alrededor del $45 \%$ del total). Con algo menos de un $20 \%$ restante, se encuentra el resto de géneros, ninguno destacado especialmente (Figura 9).

Así pues, en general, se han importado preferentemente juegos de género fantástico, terror o ciencia-ficción, mientras que en España se han desarrollado más a menudo juegos de humor, fantasía o historia. Entre otras razones, probablemente los juegos no autóctonos han sido aquellos juegos que han tenido mayor éxito en el extranjero, de temática universal y géneros tradicionales, y que podrían tener, por tanto, una mayor probabilidad de ser rentables en España. Mientras tanto, muchos juegos españoles, con una menor tirada y por tanto con un menor riesgo económico para las editoriales, han probado una mayor variedad de géneros diferentes.

Durante la primera etapa de la publicación de juegos de rol en España (E1), los géneros más representados fueron los de fantasía (11 juegos, $21 \%$ del total), ciencia-ficción (10 juegos, 19\%), historia (8 juegos, 15\%), terror (7 juegos, 13\%) y humor (4 juegos, $8 \%$; Figura 10). Así, alrededor del $75 \%$ de los juegos publicados en esta etapa pertenece a uno de esos cinco géneros y el $25 \%$ restante corresponde a otros seis géneros diferentes y en proporciones similares (Figura 10).

Sin embargo, en E2 aumenta considerablemente la proporción de juegos de fantasía (39 juegos, $32 \%$ del total), terror (27 juegos, $22 \%$ ) y humor (15 juegos, $12 \%$ ), a costa de una disminución en los juegos de ciencia-ficción (15 juegos, $12 \%$ del total) e historia (5 juegos, 4\%; Figura 11). De esta manera, los tres primeros géneros junto con el de ciencia-ficción se encuentran representados en casi un $80 \%$ del total de juegos de este período. El 20\% restante corresponde a ocho géneros diferentes, de entre los cuales destacan los multigenéricos, los de acción y los de historia (conjuntamente estos tres géneros representan el 15\% del total). En esta etapa, se prueba algún género nuevo con respecto a E1, como el erótico, el de misterio o el policíaco y desaparecen el bélico y el del oeste (Figura 11).

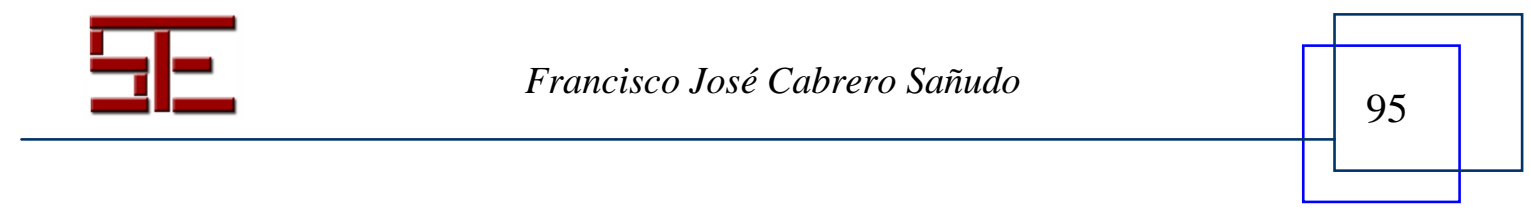




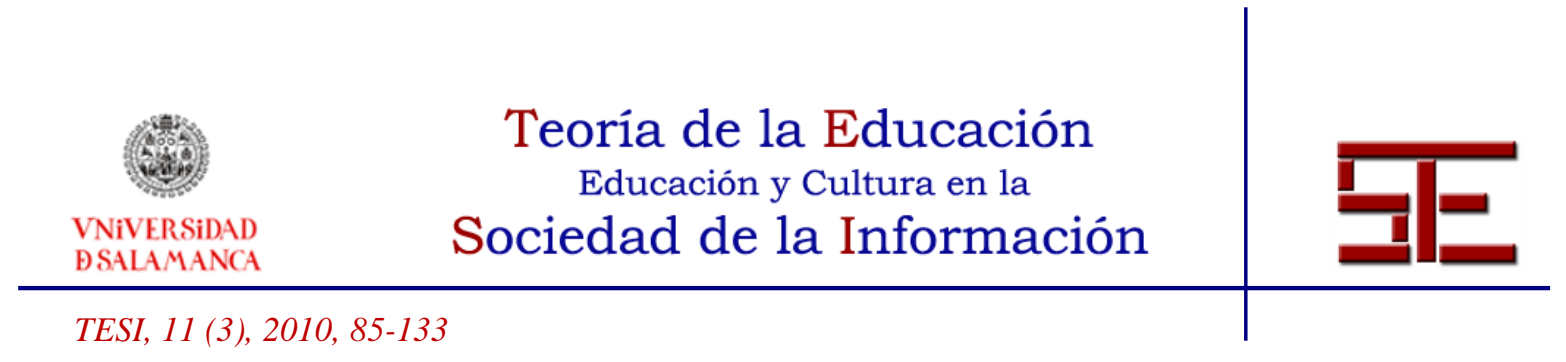

\section{2.- Publicaciones de rol en España}

\subsection{1.- Progresión de publicaciones de rol en España}

De 1985 a 2008 aparecieron en España un total de 1468 publicaciones de rol, de las cuales 253 (17\% del total) tenían un origen autóctono, mientras que 1215 (83\%) tenían un origen no autóctono (Tabla 1). Así pues, de alrededor de 60 publicaciones de rol de media al año (Tabla 2), 10 eran españolas y 50 no autóctonas. Según períodos, en E1 vieron la luz 343 publicaciones (23\%) y en E2 1125 (77\%), de modo que en esta segunda etapa se triplicó el número de publicaciones (Tabla 1), pasando de casi 30 a más de 90 publicaciones al año (Tabla 2). No obstante, si se examina cómo fue la progresión de publicaciones autóctonas, se observa que, aunque aumenta a más del doble el número de publicaciones (de 69 en E1 a 184 en E2), el porcentaje global de éstas disminuye ligeramente (de $20 \%$ en E1 a $16 \%$ en E2; Tabla 1); por el contrario, el número de publicaciones no autóctonas no sólo aumenta considerablemente a lo largo del tiempo (de 274 en E1 a 941 en E2), sino que también globalmente (de un 80\% en E1 a un $84 \%$ en E2; Tabla 1). Así, si en E1 se realizó una publicación autóctona por cada cuatro no autóctonas (en concreto, 5.75 de media al año por cada 22.83, respectivamente), en E2 la relación aumento a una por cada cinco (en concreto, 15.33 publicaciones de media al año por cada 78.42, respectivamente; Tabla 2); por consiguiente, en general, se ha potenciado cada vez más la traducción de material extranjero de rol frente a la creación de juegos y material propios.

En la Figura 12 se puede apreciar que, en términos generales, la progresión de aparición de las publicaciones de rol en España responde casi exclusivamente a la aparición de las no autóctonas, siendo las autóctonas un reflejo mucho más reducido de éstas (Figura 12). Existe un período de aumento de publicaciones desde la aparición de los juegos de rol y 1994, que coincide también con la aparición de diversos juegos de rol, fundamentalmente no autóctonos (ver también Figura 1). A continuación se produce una pequeña disminución en el número de publicaciones de rol, posiblemente coincidente con la crisis discutida anteriormente para los juegos de rol; no obstante, mientras la recesión de los juegos se produce a partir del año 1997 (Figura 1), el descenso del número de publicaciones se produce desde 1994 a 1997 (en no autóctonas) o a 1998 (en autóctonas; Figura 12). Así pues, los efectos de la supuesta crisis se produjeron en primer lugar sobre el número de publicaciones (tal vez por una disminución de ventas) y, posteriormente, esto tuvo un efecto sobre el número de juegos de nueva aparición.

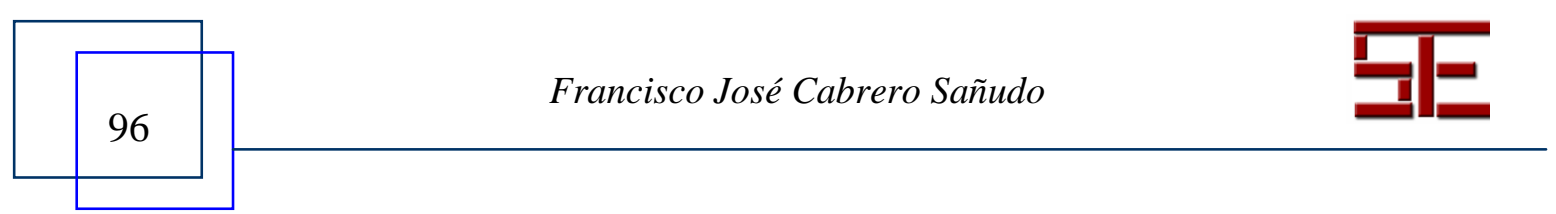




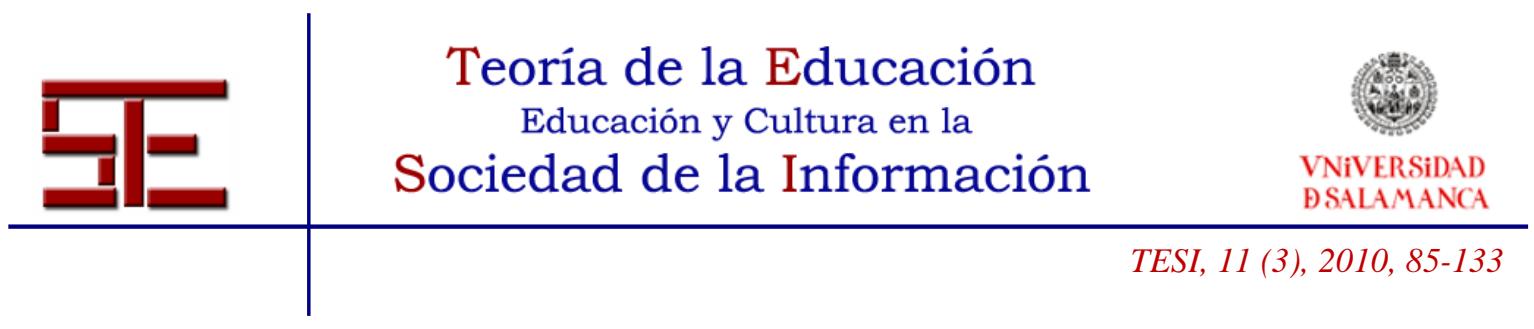

A partir de 1998 se produce un aumento continuo hasta alcanzar un pico de publicaciones en 2002 (Figura 12), coincidente con un pico en la aparición de nuevos juegos (Figura 1) y, posiblemente, debido a las mismas causas. Sin embargo, pasado este pico de publicaciones, su número ha terminado cayendo drásticamente (Figura 12); esto puede deberse a diversas causas, entre ellas, el cese de publicaciones de rol por parte de la editorial que más producía, como veremos posteriormente (La Factoría de Ideas), o el tiempo de reposo transcurrido tras la aparición en 2001 de un sistema de licencia libre, el Sistema-d20 (Wizards of the Coast Inc., 2000), que trajo consigo una gran diversidad y número de publicaciones iniciales. Finalmente, como sucedía con el número de nuevos juegos (Figura 1), el número de publicaciones autóctonas ha terminado superando al de publicaciones no autóctonas en 2008 (Figura 12). En este último período debe destacarse también la aparición de tres publicaciones de rol relacionadas con ensayos, referencias o guías de juego, no asociadas con ningún juego concreto de rol: Tras la pantalla (Muñoz et al., 2006), Creer lo increíble (Tizón, 2007) y Los juegos de rol, un acercamiento psicopedagógico (Matas, 2008).

Por otra parte, la Figura 13 muestra que la curva de publicaciones acumuladas parece haber alcanzado una asíntota en las no autóctonas, mientras que es continua y sigue en aumento en las autóctonas; esto implica que la tasa de aparición de publicaciones no autóctonas ha disminuido progresivamente a lo largo de los años, a la vez que la tasa de aparición de publicaciones autóctonas sigue aún creciendo progresivamente.

\subsection{2.- Origen de las publicaciones de rol en España}

La mayoría de las publicaciones de rol en España tiene un origen autóctono (253 publicaciones, $17 \%$ del total) o estadounidense (1105 publicaciones, $75 \%)$, mientras que el resto tiene otra procedencia, fundamentalmente anglosajona (59 publicaciones del Reino Unido y 22 de Canadá, por un total de casi un 6\% del total; Figura 14). Desde otro punto de vista, se han realizado publicaciones de hasta nueve países diferentes, exclusivamente europeos (España, Reino Unido, Francia, Polonia, Suecia y Alemania; 23\% del total) o norteamericanos (Estados Unidos, Canadá y México; 77\% del total). La mayor cantidad de publicaciones norteamericanas es consecuencia de que en este país se iniciaron los juegos de rol y es donde han tenido un mayor desarrollo, de manera que lo que ocurra con respecto a los juegos de rol en, especialmente, Estados Unidos y se publique en idioma inglés siga siendo referencia para aficionados en todo el mundo; en cierto modo, los juegos publicados en otros países tienen una menor repercusión, por

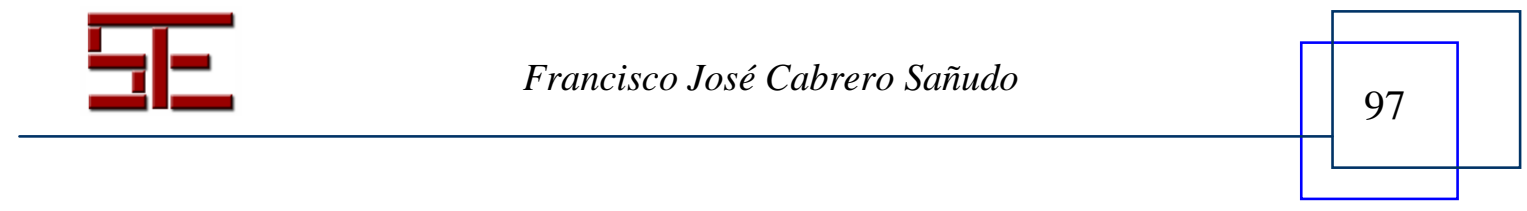




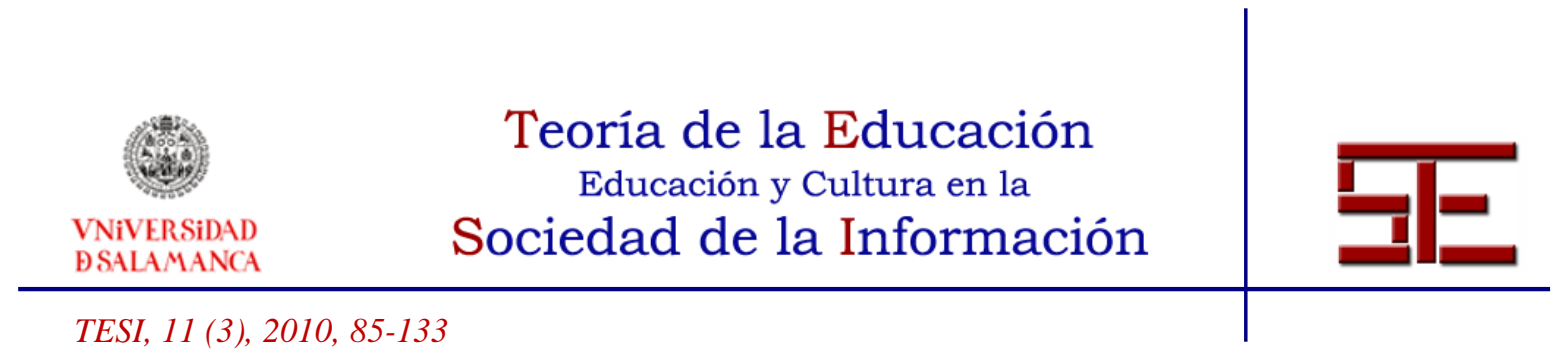

contar con tiradas menores $\mathrm{y}$, habitualmente, estar publicados en otros idiomas diferentes al inglés.

Durante E1, más del 75\% de las publicaciones de rol (263) en España tienen un origen estadounidense, mientras que sólo alrededor del 20\% (69) son autóctonas (Figura 15). También en ese período se prestó algo de atención a lo que ocurría en algún otro país europeo cercano, como Francia o Suecia, desde los cuales se tradujo alrededor de un 3\% del total (11 publicaciones; Figura 15).

Posteriormente, en E2 aumentan todas las publicaciones; no obstante, la proporción de publicaciones estadounidenses es bastante similar a la de E1 (842 publicaciones, $75 \%$ del total), pero disminuye la de publicaciones autóctonas (184 publicaciones, 17\%; Figura 16). Al mismo tiempo, se realizan publicaciones procedentes del Reino Unido (59 publicaciones, 5\%), Canadá (22 publicaciones, 2\%) o Suecia (12 publicaciones, $1 \%$ ), así como de otros orígenes discretos, como Francia, Polonia, México o Alemania (6 publicaciones, <1\%; Figura 16). Por tanto, junto con las publicaciones autóctonas de rol, se atiende a las que aparecen en Estados Unidos y países de habla inglesa, aparte de que se publica material de calidad que ha ido apareciendo progresivamente en otros países, conocido gracias a una mayor información sobre rol disponible a través de las nuevas tecnologías de comunicación.

\subsection{3.- Distribución de las publicaciones de rol en España según los juegos correspondientes}

La media de publicaciones de rol por juego es de 8.41, en general casi cuadruplicando la de los juegos no autóctonos (12.04) a la de los autóctonos (3.26; Tabla 2). La diferencia de publicaciones/juego entre períodos no difiere mucho (6.45 en E1 frente a 7.68 en E2), pero en el segundo hay más variación de publicaciones entre juegos (es decir, unos juegos con muchas publicaciones y otros con pocas, mientras que en E1 el número de publicaciones/juego es más homogéneo; ver desviaciones estándar en Tabla 2). Con respecto a los juegos autóctonos, el número de publicaciones por juego disminuye con el tiempo, pasando de 3.94 en E1 a 2.67 en E2 (Tabla 2); este dato, junto con sus desviaciones estándar, muestra que, en general, aunque en E2 haya algún juego con bastantes publicaciones, a lo largo del tiempo se tiende principalmente a publicar juegos con pocos suplementos o incluso con un solo manual. En cuanto a los juegos no autóctonos, el número de publicaciones por juego aumenta en más de un 50\%, pasando de 7.64 en E1 a 11.48 en E2 (Tabla 2); en este caso, pese a que, por lo general, se tiende

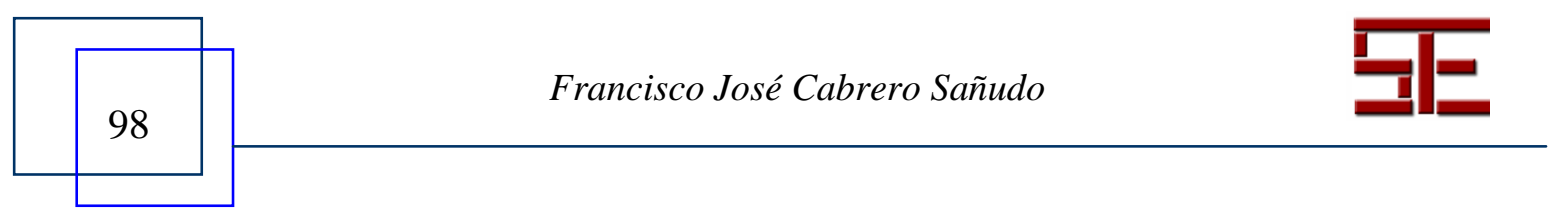




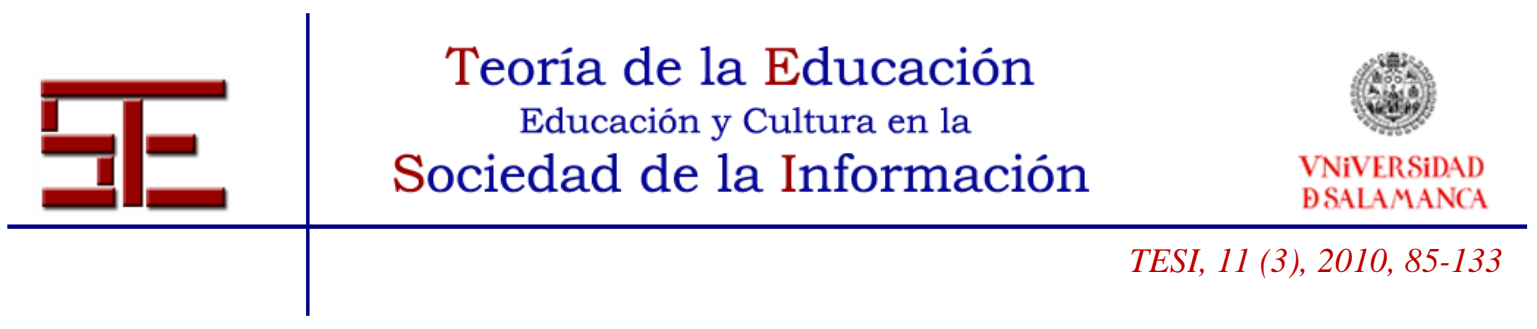

a publicar más suplementos para los juegos no autóctonos, la desviación estándar también revela que algunos pocos juegos presentan una gran cantidad de publicaciones (en concreto, los de líneas de juegos ya establecidas y más populares, como Mundo de Tinieblas o Dungeons \& Dragons).

La Figura 17 muestra cuáles han sido los diez juegos de rol con mayor número de publicaciones en España, los cuales representan alrededor del $45 \%$ del total. Los tres primeros puestos se encuentran ocupados por juegos de la línea de Dungeons \& Dragons (Advanced D\&D 2 ${ }^{\mathrm{a}}$ Ed. [Cook, 1992], D\&D 3/3.5 ${ }^{\mathrm{a}}$ Eds. [Cook et al., 2001, 2003] y aquellas publicaciones genéricas del Sistema-d20 [Wizards of the Coast Inc., 2000], identificable con las ediciones $3 / 3.5^{\mathrm{a}}$ ); para esta línea se ha realizado más de un $20 \%$ del total de material de rol en España (Figura 17). Tres de los diez juegos también pertenecen a la línea del Mundo de Tinieblas (Vampiro, la mascarada [Rein•Hagen, 1993], Hombre lobo, el apocalipsis [Rein•Hagen, 1995] y Mago, la ascensión [Wieck et al., 1996]); entre los tres contienen más de un 10\% del total de publicaciones de rol en España (Figura 17), pero si se considera toda la línea ésta acumula por sí sola más de un $30 \%$ del total. El Señor de los Anillos - MERP (Charlton, 1989) y La llamada de Cthulhu (Petersen, 1988) son dos juegos clásicos, con una amplia vida de publicación, que también se encuentran entre los diez con más publicaciones; entre los dos representan conjuntamente alrededor del 8\% de las publicaciones de rol (Figura 17). Otro juego presente en esta clasificación es La leyenda de los 5 anillos (Wick, 1998), que constituye el 3\% (42) del total de publicaciones en España (Figura 17). El único juego completamente autóctono que entra a formar parte de esta lista es Aquelarre (Ibáñez, 1990), con casi el 3\% (38) del total de publicaciones.

Considerando exclusivamente los juegos autóctonos (Figura 18), Aquelarre, juego histórico fantástico, alcanza el 15\% de las publicaciones de rol en España. Dos juegos de superhéroes, Mutantes en la sombra (Garzón y Arriola, 1991) y Superhéroes Inc. (López-Herrero et al., 1994) ostentan los segundos puestos, representando también el $15 \%$ del total (Figura 18). El único juego presente de terror es Ragnarok (Equipo de Diseño de Ludotecnia, 1992). Se presentan también dos juegos de humor (Fanhunter [Pamundi et al., 1993] y Fanpiro [Alabort y Pol, 2001]), algunas publicaciones autóctonas para el Sistema-d20 (Wizads of the Coast Inc., 2000), un juego de cienciaficción (Exo [Herreros et al., 1999]), un juego bélico (Comandos de guerra [Herreros, 1990]) y otro juego histórico (Piratas!! [Romero-Salazar, 1994]); los diez juegos juntos contienen más del $52 \%$ del total de publicaciones autóctonas.

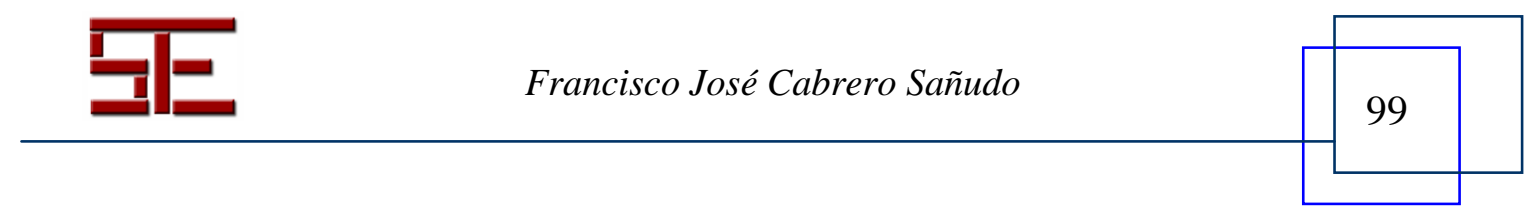




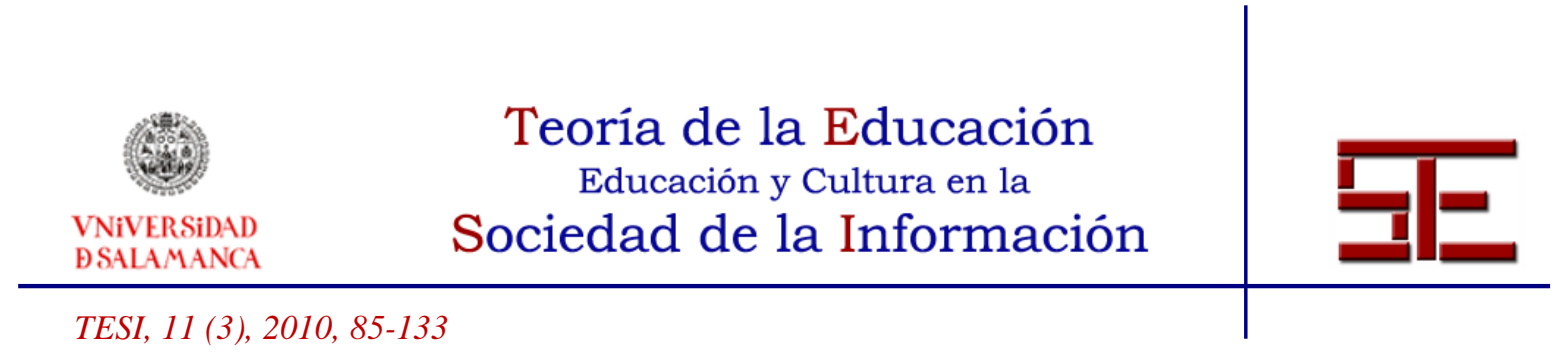

En cuanto a los diez juegos no autóctonos con más publicaciones (Figura 19), se mantienen los mismos y en el mismo orden observado al considerar a todas las publicaciones juntas (Figura 17), sustituyendo el juego de Aquelarre (Ibáñez, 1990) por el de Vampiro, edad oscura (Hartshorn et al., 1996), perteneciente a la línea del Mundo de Tinieblas. Estos diez juegos representan conjuntamente alrededor del $48 \%$ del total de publicaciones no autóctonas en España (Figura 19). Así pues, tanto en lo que se refiere a juegos autóctonos como no autóctonos, un total de diez juegos, respectivamente, acaparan la mitad de las publicaciones realizadas en España (Figuras $18,19)$.

Según etapas, en E1 destacan once juegos que aportan casi dos terceras partes de todas las publicaciones realizadas en este período (Figura 20); poseen entre nueve y 60 publicaciones, mientras que el resto de los juegos (42 restantes) tienen menos de 9 publicaciones. Aparte de algunos juegos que aparecen en la clasificación de autóctonos y de no autóctonos (Figuras 18, 19), se observan también los juegos de Runequest (Stafford, 1988), Star Wars sistema-d6 (Costikyan et al., 1990), Cyberpunk (Pondsmith, 1993) y Shadowrun (Dowd, 1993; Figura 20). Durante E2, diez juegos ostentan alrededor del $45 \%$ del total de publicaciones durante ese período (Figura 21); así, durante este período parece existir una menor cantidad de juegos acaparando el mercado, en comparación con E1, y las publicaciones se encuentrarían más repartidas entre juegos. Estos diez juegos tienen publicados entre 27 y 115 suplementos, mientras que el resto de juegos (111 restantes) posee menos de 25. En dicho listado se muestran ocho de los diez juegos de la clasificación general (Figura 17), junto con Vampiro, edad oscura (Hartshorn et al., 1996), que se encuentra entre los diez no autóctonos con más publicaciones (Figura 19) y $7^{\circ}$ Mar (Wick et al., 2000), un juego no autóctono de fantasía, con un sistema de juego similar al de La leyenda de los 5 anillos (Wick, 1998).

\section{3.- Editoriales de rol en España}

\subsection{1.- Progresión de editoriales de rol en España}

A lo largo de 22 años, un total de 45 editoriales han realizado publicaciones de juegos de rol en España, 20 de ellas (alrededor del 45\%) en E1 y 33 (casi el 75\%) en E2 (Tabla 3). Aparte de estas editoriales, 20 publicaciones han salido a la luz como autopublicaciones, muchas de ellas a través de la empresa de servicios de publicación Lulú (http://www.lulu.com/es). De las 45 editoriales, hasta 27 de ellas (60\%) han publicado exclusivamente material autóctono, 10 (22\%) exclusivamente no autóctono y

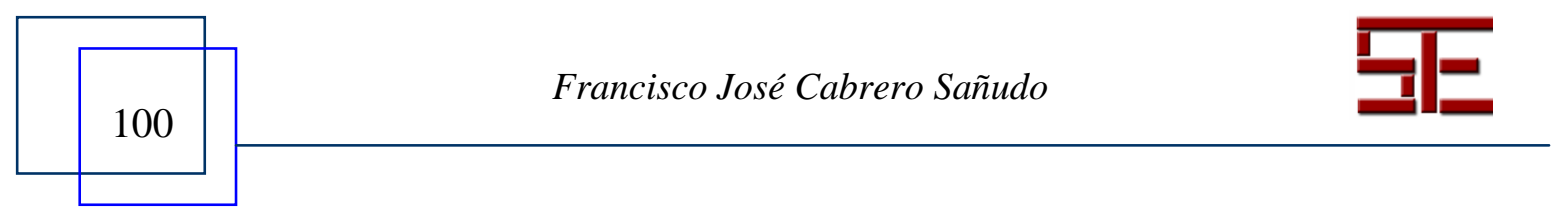




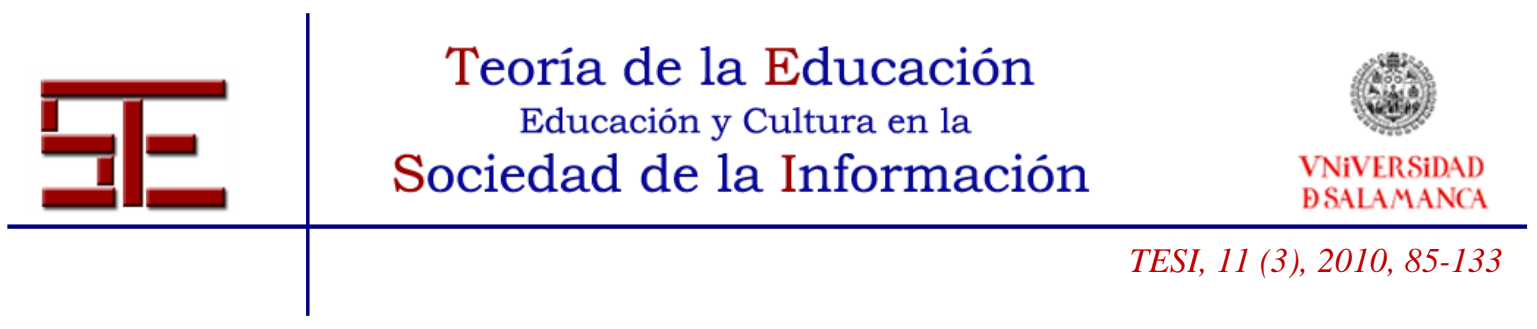

8 (18\%) tanto publicaciones autóctonas como no autóctonas (Tabla 3); así pues, más de tres cuartas partes del total de editoriales han realizado publicaciones autóctonas. Durante E1, el número de editoriales que publicaban sólo material autóctono fue similar al de las que publicaban sólo material traducido (9 frente a 8, respectivamente), mientras que sólo tres realizaba publicaciones de ambos orígenes (Tabla 3). Por el contrario, en E2 el número de editoriales con publicaciones autóctonas y con mezcla de publicaciones se duplicó y superó (20 y 8, respectivamente), mientras que el de editoriales que publicaban material no autóctono casi se redujo a la mitad (5 editoriales; Tabla 3). Así pues, en general, con el paso del tiempo ha aumentado el número de editoriales que sacan publicaciones autóctonas, mientras que se ha reducido el número de editoriales dedicadas sólo a publicaciones traducidas. En cierto modo, este material traducido conlleva el pago adicional de licencias, que no todas las editoriales pueden sufragar; por ello, quizás ha aumentado el número de editoriales que compaginan ambas fuentes de publicaciones.

En la Figura 22 se representa el número de editoriales que han realizado publicaciones de rol en España anualmente. Durante E1, se observa un aumento en el número de editoriales hasta los años 1994-1996 (Figura 22); en este momento, el número de editoriales que publican juegos no autóctonos experimenta su máximo. En los primeros años de E2, se produce un descenso considerable, especialmente en el número de editoriales que publican material autóctono, que coincide con el descenso en el número de juegos de rol publicados (Figura 1) y que había sido precedido por una disminución en las publicaciones (Figura 12), posiblemente por las causas observadas anteriormente. No obstante, a partir del año 2000 el número de editoriales vuelve a aumentar, sobre todo el de las editoriales de publicaciones autóctonas, propiciado fundamentalmente por las causas esgrimidas anteriormente para los juegos y publicaciones. Desde el año 2002, el número de editoriales que publican material de rol ha sido variable, de entre 6 a 11 al año (Figura 22), como consecuencia de depender principalmente de las editoriales de material autóctono (que publican con una menor frecuencia o que publican durante un corto período y desaparecen); se trata de un momento de inestabilidad mientras se prueban nuevas formas de publicación, se observa qué ocurre con los juegos tradicionales (que han podido sufrir cambios de sistema o de licencia) y se experimentan nuevas variaciones de juegos de rol.

La curva de acumulación de editoriales a lo largo del tiempo muestra diferentes períodos de aparición de editoriales, pero, en general, el ritmo de aparición de editoriales que realizan publicaciones no autóctonas ha sido más lento que el de

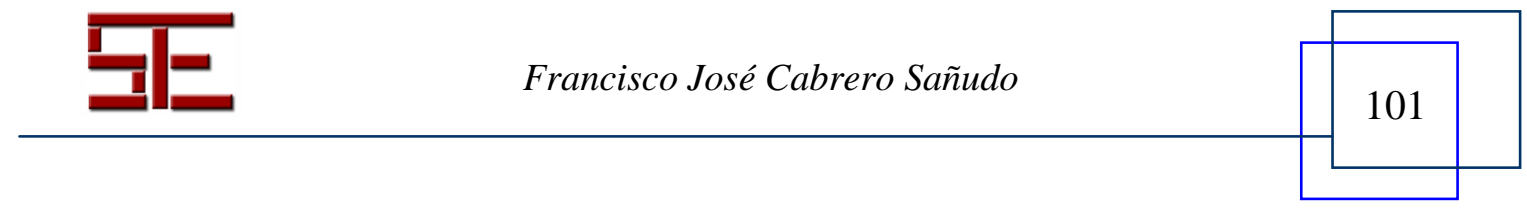




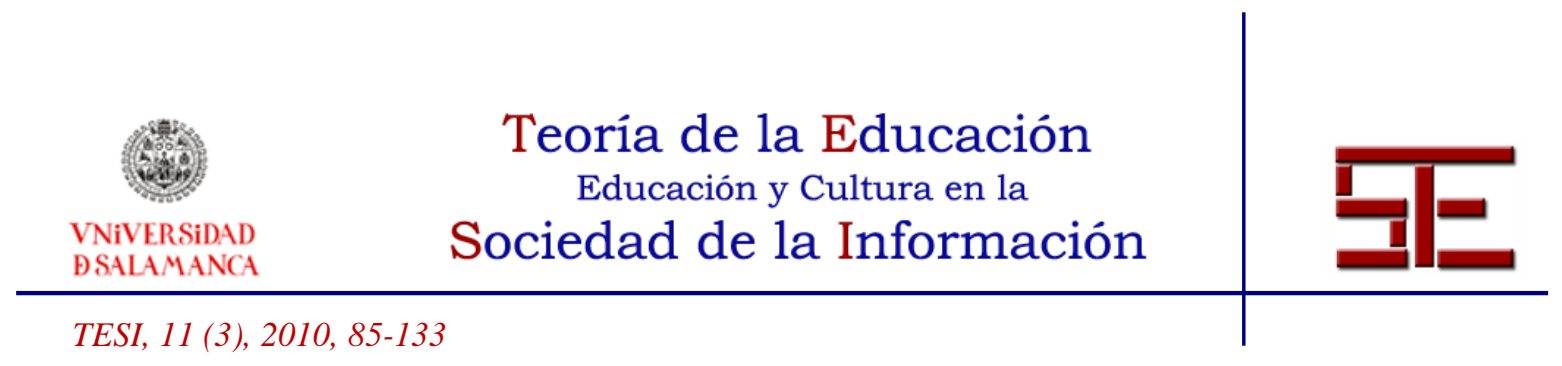

editoriales con material autóctono (Figura 23). Durante E1 hay un período de aparición lento de editoriales hasta 1989, durante el cual las editoriales con material no autóctono son más que las de material autóctono. No obstante, a partir de 1990 el número de editoriales con material autóctono supera al de editoriales con material no autóctono (Figura 23). Al comienzo de E2 se produce una reducción en la aparición de editoriales, que se supera a partir de 1998 (Figura 23). Desde 1998 hasta 2002 hay un crecimiento rápido, especialmente superior en las editoriales que publican juegos autóctonos, que ha vuelto a relajarse, aunque sigue aumentando progresivamente, desde 2003 hasta 2008 (Figura 23).

Durante 1985 a 2008, la editorial con una mayor vida de publicación ha sido Ludotecnia, seguida por La Factoría de Ideas (ambas en activo actualmente) y Joc Internacional (extinta; Figura 24). También se encuentran entre las más longevas Ediciones Sombra, Edge Entertainment, Devir, Ediciones Zinco o Farsa's Wagon, las tres primeras aún activas, mientras que las dos últimas ya desaparecidas (Figura 24). Así pues, de las editoriales surgidas durante E1, sólo Ludotecnia y La Factoría de Ideas continúan en el presente. Muchas de las editoriales de E1 terminaron desapareciendo a comienzos de E2, momento en que, además, se crearon pocas editoriales (Figura 24), posiblemente debido a los efectos de la crisis de los juegos de rol. En E2, sobre todo los primeros años, aparece un amplio número de editoriales, muchas de las cuales terminan desapareciendo en un corto plazo (Figura 24).

En la Tabla 2 se muestra la vida media de las editoriales. Como se puede observar, las editoriales han tenido, en general, una vida media de más de tres años y medio, siendo las editoriales con material no autóctono aquellas que han perdurado generalmente más que las de material autóctono (Tabla 2). Posiblemente, muchas de las que se han decidido a publicar productos traducidos tienen que contar con cierta estabilidad inicial para poder pagar costes adicionales (licencias, traducciones, etc.) y, por tanto, suelen ser más resilientes que las editoriales con material autóctono.

\subsection{2.- Origen de las editoriales de rol en España}

La gran mayoría de editoriales que publican juegos de rol en España tienen un origen español (40 editoriales; 89\% del total; Figura 25). Sólo una pequeña representación de editoriales no españolas han fundado sedes españolas o ha publicado productos en español (5 editoriales; $11 \%$ del total; Figura 25). Así pues, el fenómeno de los juegos de

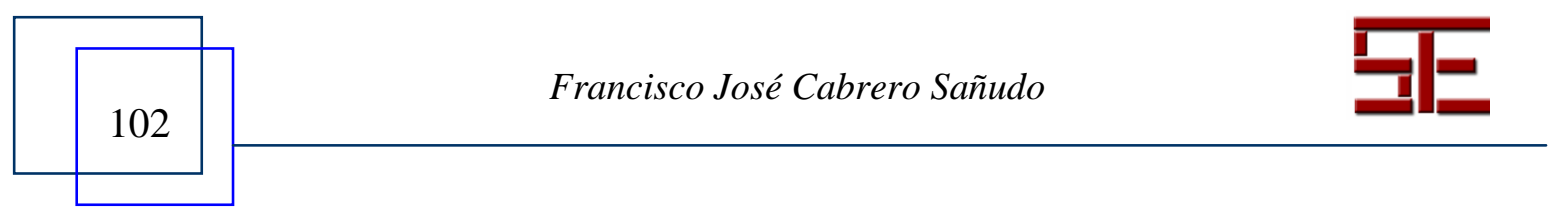




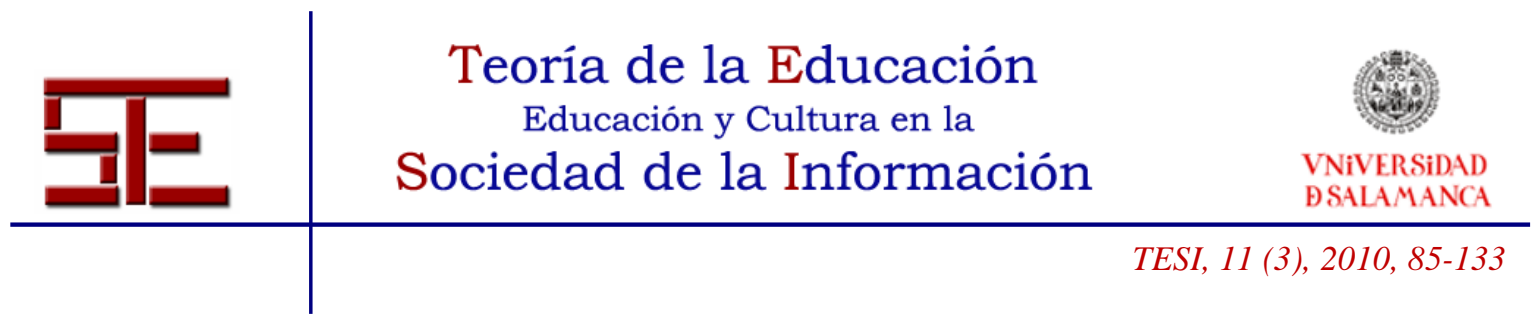

rol en España ha estado principalmente protagonizado por editoriales españolas, independientemente del origen de sus juegos o publicaciones.

\subsection{3.- Distribución de las editoriales de rol en España según los juegos publicados}

El número medio de juegos por editorial en España desde 1985 a 2008 es de 4.33, aunque el número es en realidad superior para editoriales que publican juegos no autóctonos (5.73) e inferior (menos de la mitad) para editoriales de juegos autóctonos (2.16; Tabla 2). Según períodos, en E1 el número de juegos por editorial fue de 2.95 y posteriormente aumentó en E2 a 4.70 (Tabla 2). En cualquiera de los dos períodos, este valor siempre ha sido superior y como mínimo el doble en editoriales que publican juegos no autóctonos con respecto a editoriales con juegos autóctonos (Tabla 2). Por lo tanto, las editoriales que publican material autóctono, en general, se han dedicado a un número más reducido de juegos, probablemente como consecuencia de que muchas de ellas eran fundadas por el autor a partir de un único juego y según su éxito continuaron, o no, publicando material de otros juegos.

Un total de 12 editoriales (poco más del 25\% del total) ha publicado suplementos para cuatro o más juegos (Figura 26). La editorial que ha publicado material para un mayor número de juegos es La Factoría de Ideas, con 50 juegos, lo que representa como mínimo el doble que cualquier otra editorial (Figura 26). Edge Entertainment y Joc Internacional, las siguientes dos editoriales que han atendido a un mayor número de juegos, han publicado suplementos para 23 y 22 juegos, respectivamente (Figura 26). Por debajo de ellas se encuentran NSR Ediciones con 14 juegos, Devir con 10 ó Proyectos Editoriales Crom con 9 juegos (Figura 26).

En cuanto al origen de los juegos, la editorial con material para más juegos autóctonos se trata de NSR Ediciones (11 juegos), seguida de Proyectos Editoriales Crom (8 juegos; Figura 27), mientras que las editoriales con suplementos para un número mayor de juegos no autóctonos son La Factoría de Ideas (46 juegos), Edge Entertainment (21 juegos) y Joc Internacional (con 18 juegos; Figura 28).

Según períodos, en E1 destacan las editoriales de Joc Internacional (con material para 21 juegos diferentes) y La Factoría de Ideas (con material para 6 juegos; Figura 29). Posteriormente en E2 es La Factoría de Ideas la editorial con un mayor número de juegos tratados (50 juegos), seguida de Edge Entertainment (23 juegos), NSR Ediciones (14 juegos), Devir (10 juegos) o Proyectos Editoriales Crom (9 juegos; Figura 30).

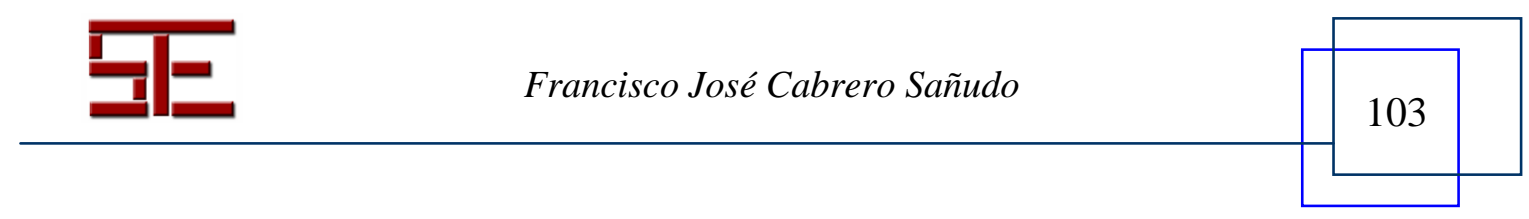




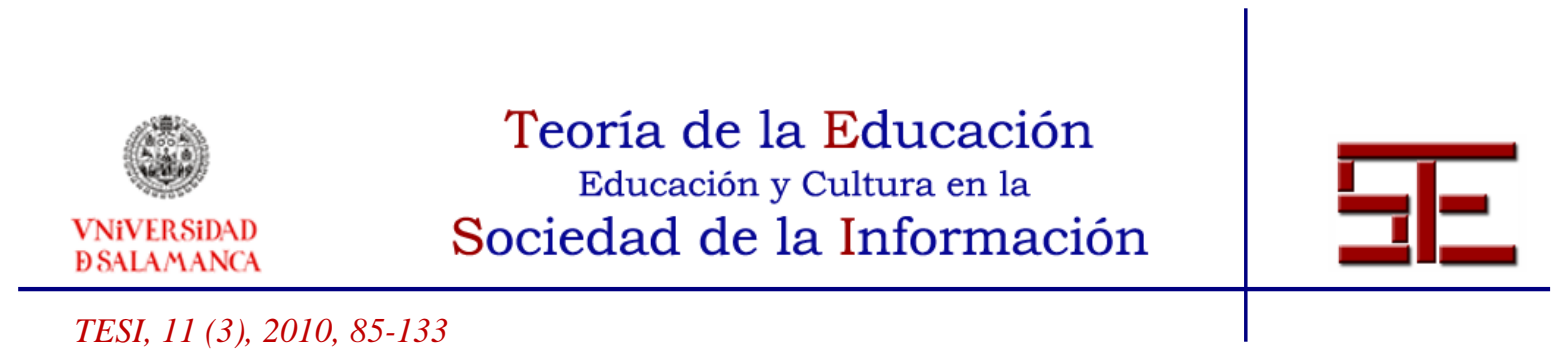

Como se observa, estas editoriales, principales protagonistas del fenómeno de los juegos de rol como consecuencia de publicar para un mayor número de juegos, han gravitado hacia juegos de un cierto origen (autóctono o no autóctono), en vez de repartir esfuerzos en publicar juegos independientemente de su origen. Por así decirlo, aunque pudieran publicar material de uno $\mathrm{u}$ otro origen, se suelen especializar o bien en juegos autóctonos, o bien en no autóctonos.

\subsection{4.- Distribución de las editoriales de rol en España según sus publicaciones}

El número medio de publicaciones de rol por editorial es de 32.18 (Tabla 2). No obstante, si se trata de publicaciones autóctonas, el número medio disminuye a tan sólo 6.66 y, si se trata de no autóctonas, aumenta en comparación más de diez veces, hasta 67.50 (Tabla 2). Durante E1, el número medio de publicaciones por editorial era casi la mitad de la media global (17.15), mientras que en E2 se supera dicha media global ligeramente hasta 33.48 (Tabla 2). En cualquiera de los dos períodos, el número medio de publicaciones por editorial es siempre mayor en no autóctonas que en autóctonas; esto es consecuencia de que, en general, se dispone de mayor cantidad de material no autóctono que autóctono. Además, mientras que el número de publicaciones autóctonas por editorial aumenta sólo ligeramente entre ambos períodos (de 5.67 en E1 a 6.67 en E2), el número de publicaciones no autóctonas casi se triplica (de 27.09 en E1 a 72.39 en E2; Tabla 2). En cualquier caso, este resultado tiene una desviación estándar extremadamente amplia (Tabla 2), de modo que habría pocas editoriales con muchas publicaciones y muchas editoriales con pocas.

Alrededor de la mitad de las publicaciones de rol publicados en España corresponden a una sola editorial, La Factoría de Ideas (Figura 31). Esta editorial junto con otras tres, Devir, Edge Entertainment y Joc Internacional, han publicado en España más de un $75 \%$ de todo el material de rol existente (la última ya extinta; Figura 31). Un 17\% del material de rol ha sido publicado por otras siete editoriales (Zinco, Ludotecnia, NSR Ediciones, Proyectos Editoriales Crom, M+D Editores, La Caja de Pandora y MartínezRoca).

En cuanto a publicaciones autóctonas, alrededor del 50\% ha sido publicado en España por cuatro Editoriales: Ludotecnia, NSR Ediciones, Proyectos Editoriales Crom y La Caja de Pandora (las dos primeras siguen activas; Figura 32). Más de un $25 \%$ ha sido publicado por otras seis editoriales: Joc Internacional, La Factoría de Ideas, Ediciones Sombra, Cronópolis, Farsa's Wagon y Edge Entertainment (Figura 32). Por el contrario,

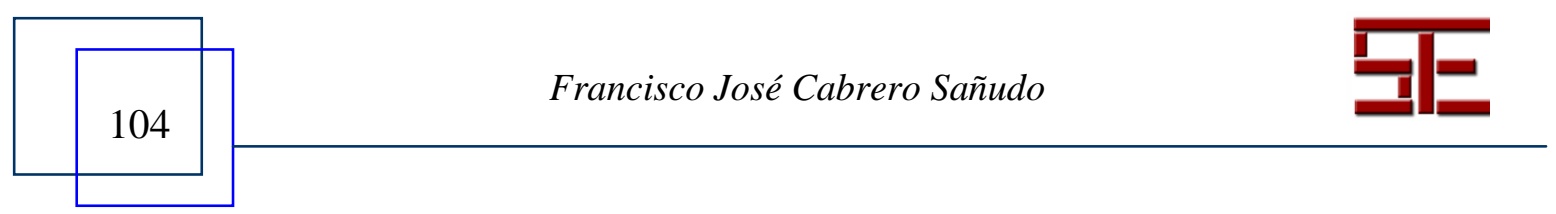




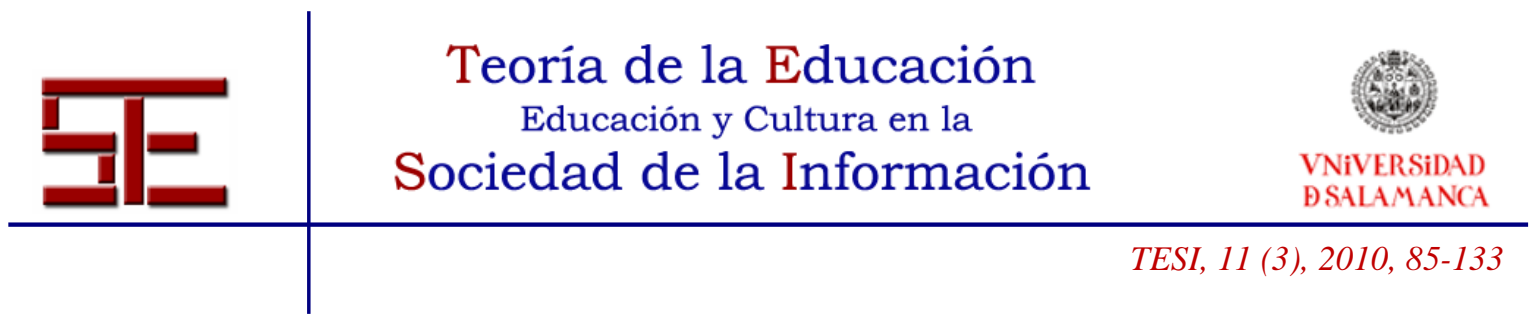

alrededor de un $57 \%$ de las publicaciones no autóctonas pertenecen a la editorial La Factoría de Ideas, mientras que alrededor del $37 \%$ restante son de otras cuatro editoriales: Devir, Edge Entertainment, Joc Internacional y Zinco (las dos últimas ya extintas; Figura 33). Por tanto, la publicación de material de rol autóctono parece haber estado más repartida entre editoriales, mientras que el material no autóctono se ha concentrado más en unas pocas.

Durante E1, la editorial con mayor número de publicaciones es Joc Internacional con alrededor de un $43 \%$ del total, aunque también destacan Zinco, La Factoría de Ideas, Ludotecnia o M+D Editores; entre todas ellas, se publica el $86 \%$ del total de suplementos de rol (Figura 34). En E2, La Factoría de Ideas publica alrededor del 60\% del material de rol en España, aunque también destacan Devir y Edge Entertainment (con un 21\% conjunto de las publicaciones de rol en este período; Figura 35). Así, aunque se observa una concentración de publicaciones de rol en unas pocas editoriales, en el primer período las publicaciones se encuentran más repartidas entre las editoriales que en el segundo período, en el que una de ellas predomina sobre las demás (La Factoría de Ideas).

\section{4.- CONCLUSIONES FINALES}

A modo de conclusiones finales, se ha querido exponer una serie de predicciones acerca del futuro de la publicación de juegos de rol en España. Estas predicciones son simplemente especulativas y se encuentran basadas, entre otras opiniones, en las tendencias observadas en los análisis anteriores.

1. Es probable que aparezcan progresivamente un mayor número de juegos autóctonos y a medio o largo plazo terminen por superar a los juegos no autóctonos publicados en España.

2. Gracias a una mayor comunicación y contacto entre aficionados de todo el mundo, consecuencia de la globalización y de las nuevas comunicaciones, es posible que haya una diversidad cada vez mayor de orígenes de juegos de rol, publicándose en España cualquier juego exitoso, independientemente de su origen.

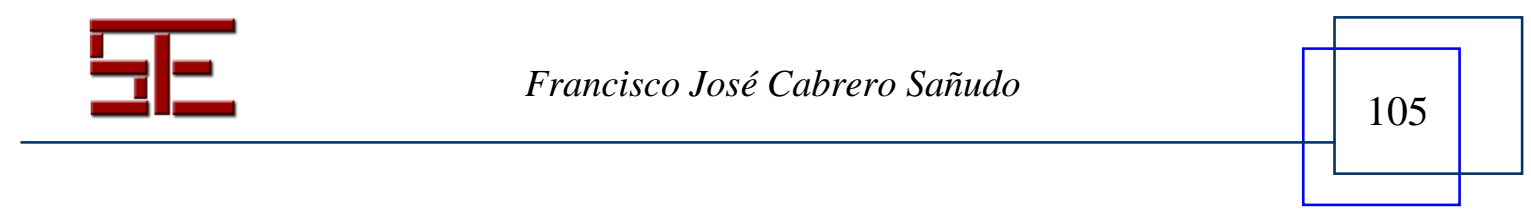




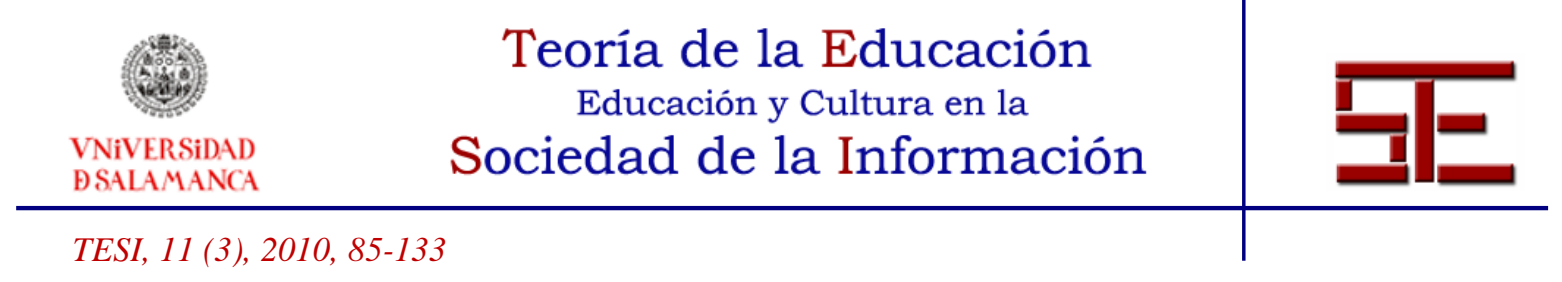

3. Los géneros más populares de los juegos de rol seguirán siendo probablemente el fantástico, el de terror, el de ciencia-ficción, el histórico y el de humor. Muchos de los juegos no autóctonos publicados próximamente en España serán de uno de los tres primeros géneros anteriores.

4. Es probable que con una frecuencia cada vez mayor sigan apareciendo nuevos juegos contenidos en un único manual y sin muchas más publicaciones posteriores.

5. La popularización de sistemas de juego con licencias libres, como el Sistema-d20 (Wizards of the Coast, 2000, 2008) o el Fudge (O’Sullivan, 1995) favorecerá la aparición de más juegos o publicaciones.

6. El interés por los conocidos como juegos indies, caracterizados por intentar romper con las reglas tradicionales de los juegos de rol, también favorecerá la aparición creciente de nuevos juegos.

7. Es bastante probable que en los juegos autóctonos publicados se tienda más a experimentar que en los no autóctonos, de los cuales se tenderá a publicar material contrastado previamente o con cierto renombre. De esta manera, se publicarán más juegos españoles que no autóctonos, pero saldrán a la luz más publicaciones no autóctonas que españolas.

8. Algunos de los juegos clásicos que ya han demostrado su popularidad y valía volverán tal vez a ser reeditados o publicados de nuevo, como ya se ha anunciado para Aquelarre (Ibáñez, 1990) o La Llamada de Cthulhu (Petersen, 1988).

9. Las publicaciones de rol autóctonas seguirán seguramente aumentando e incluso podrán superar anualmente a las no autóctonas traducidas. Sin embargo, se ha empezado a sentir y se seguirá sintiendo, a corto y medio plazo, una disminución considerable en las publicaciones de rol no autóctonas, propiciada especialmente por la desaparición de publicaciones pertenecientes a la editorial La Factoría de Ideas.

10. Las publicaciones estadounidenses y, en general, aquellas en idioma inglés seguirán siendo a corto y medio plazo la referencia para los aficionados a los juegos de rol en España.

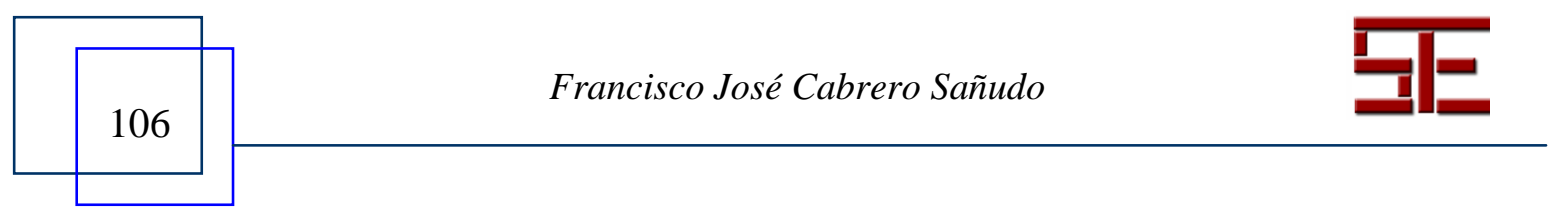




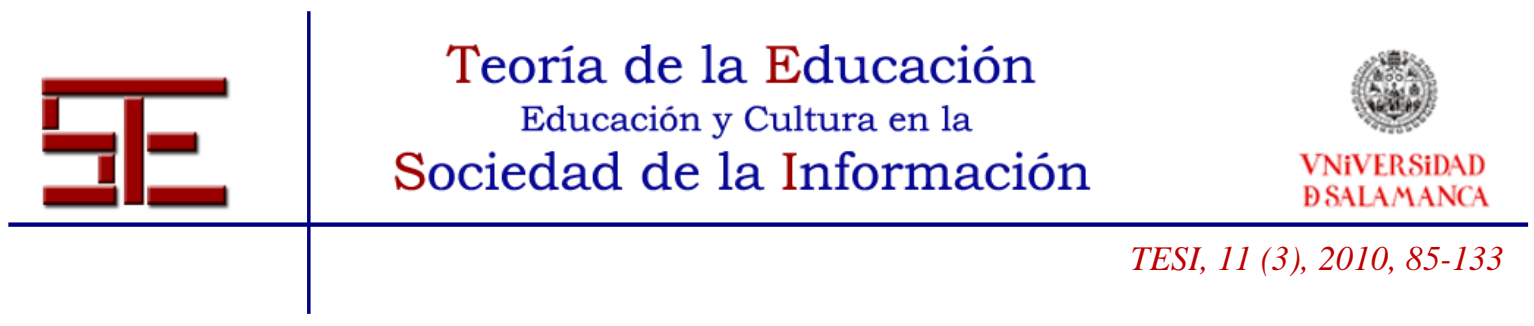

11. El número de autopublicaciones y de publicaciones relacionadas con los juegos de rol, pero no exclusivas de ningún juego (ayudas, ensayos, aplicaciones, etc.) aumentará progresivamente.

12. La línea de Dungeons \& Dragons continúa activa por el momento y, por consiguiente, se seguirán publicando bastantes suplementos de ella. La otra línea, anteriormente exitosa, de Mundo de Tinieblas ha quedado discontinuada, como consecuencia de que la editorial que poseía la licencia (La Factoría de Ideas) ha dejado de publicarla y, por tanto, sus aficionados terminarán probablemente saltando a otros juegos.

13. El número de editoriales de material de rol autóctono seguirá posiblemente en aumento, debido a una creciente facilidad de publicación; por el contrario, seguramente se estabilizará o disminuirá el número de editoriales de material no autóctono, monopolizándose en unas pocas.

14. La mayor parte o casi la totalidad de las editoriales de rol seguirán siendo españolas.

15. Pese a que cada vez pueda haber más editoriales que compaginen la publicación de material autóctono y no autóctono, se tenderá a que las editoriales se especialicen cada vez más hacia uno de estos tipos de material.

16. Las editoriales actualmente establecidas y con cierta vida de publicaciones probablemente seguirán publicando a corto y largo plazo.

17. Una posible fórmula para el éxito de una editorial se podría observar en la trayectoria de La Factoría de Ideas, la editorial más exitosa hasta el momento en cuanto a juegos de rol en España. En un primer período obtuvo una rápida diversidad de juegos (evitó especializarse en alguno concreto) y aportó principalmente material no autóctono traducido al mercado español (junto con algunas incursiones en material autóctono); en un segundo período, tras haber experimentado con varios juegos, optó por especializarse en algunos de ellos, publicando para estos gran cantidad de material.

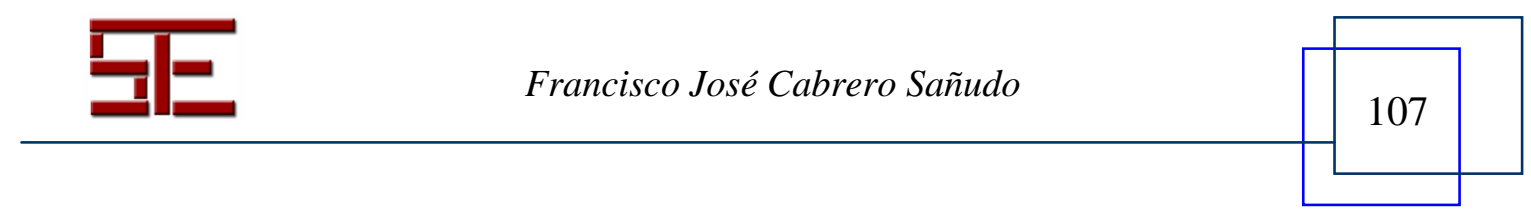




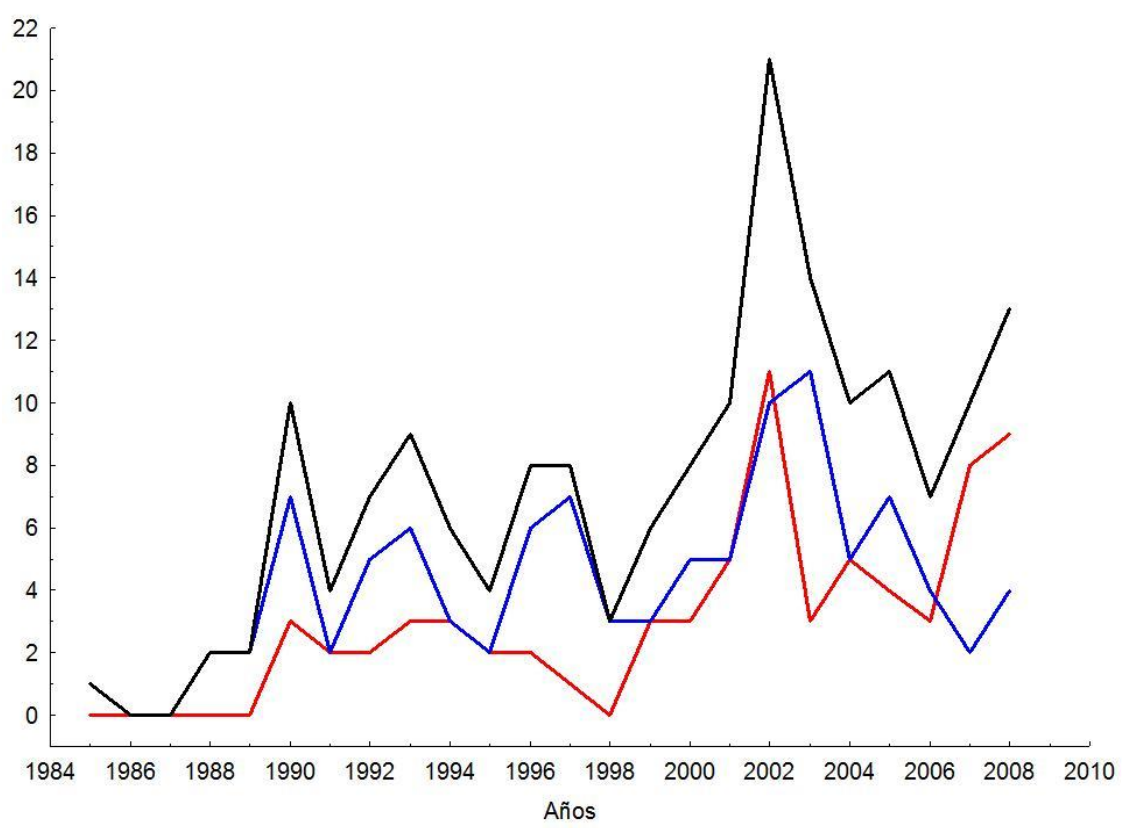

Figura 1. Progresión de aparición de los juegos de rol publicados en España. En negro, el número total de juegos de rol; en azul, los juegos de rol no autóctonos; en rojo, los juegos de rol autóctonos. 

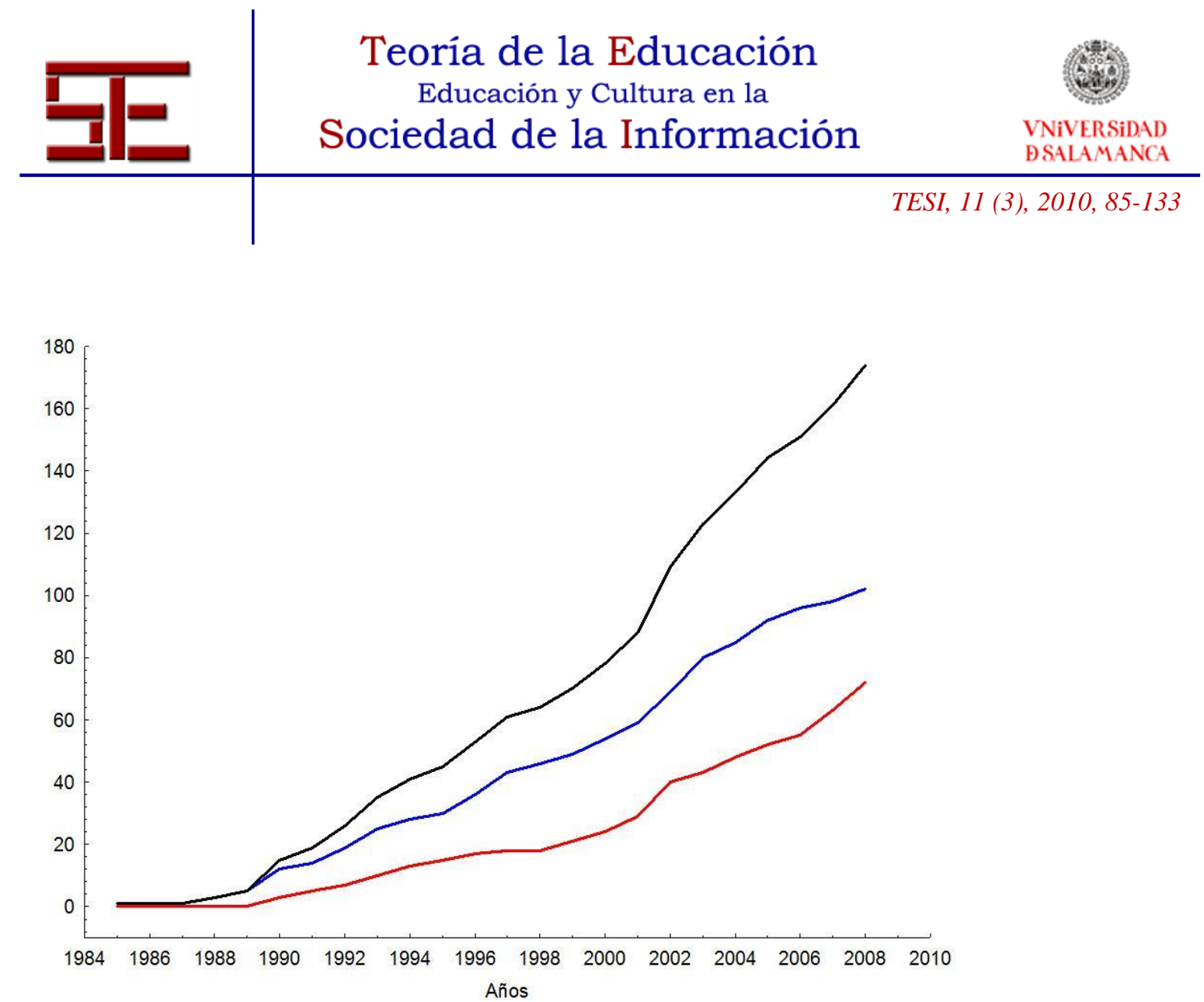

Figura 2. Acumulación de juegos de rol publicados en España. En negro, todos los juegos de rol; en azul, los juegos de rol no autóctonos; en rojo, los juegos de rol autóctonos.

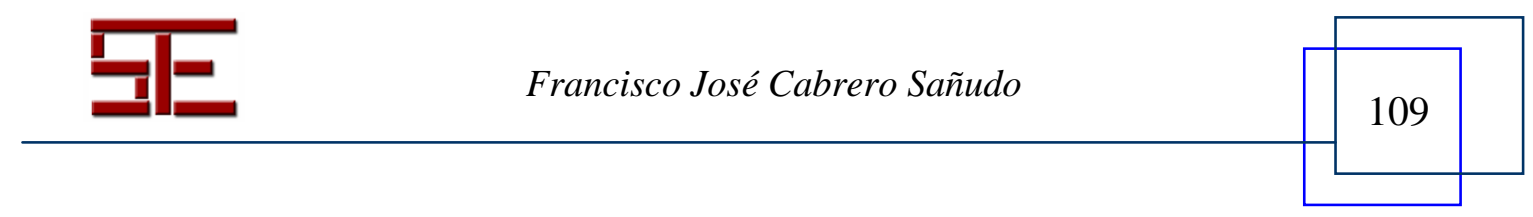




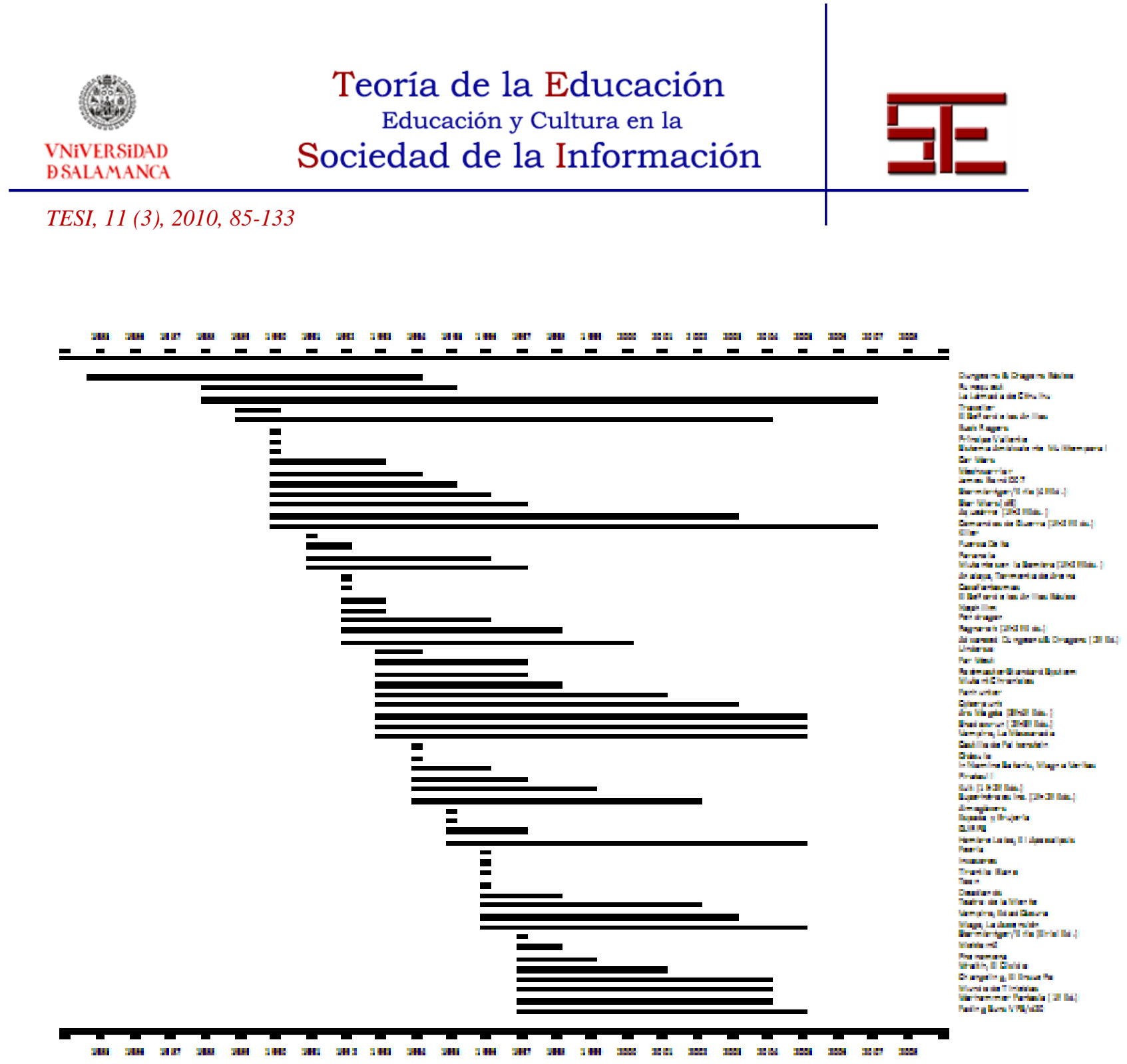

110 


\begin{tabular}{c|cc} 
Teoría de la Educación \\
Educación y Cultura en la \\
Sociedad de la Información
\end{tabular}
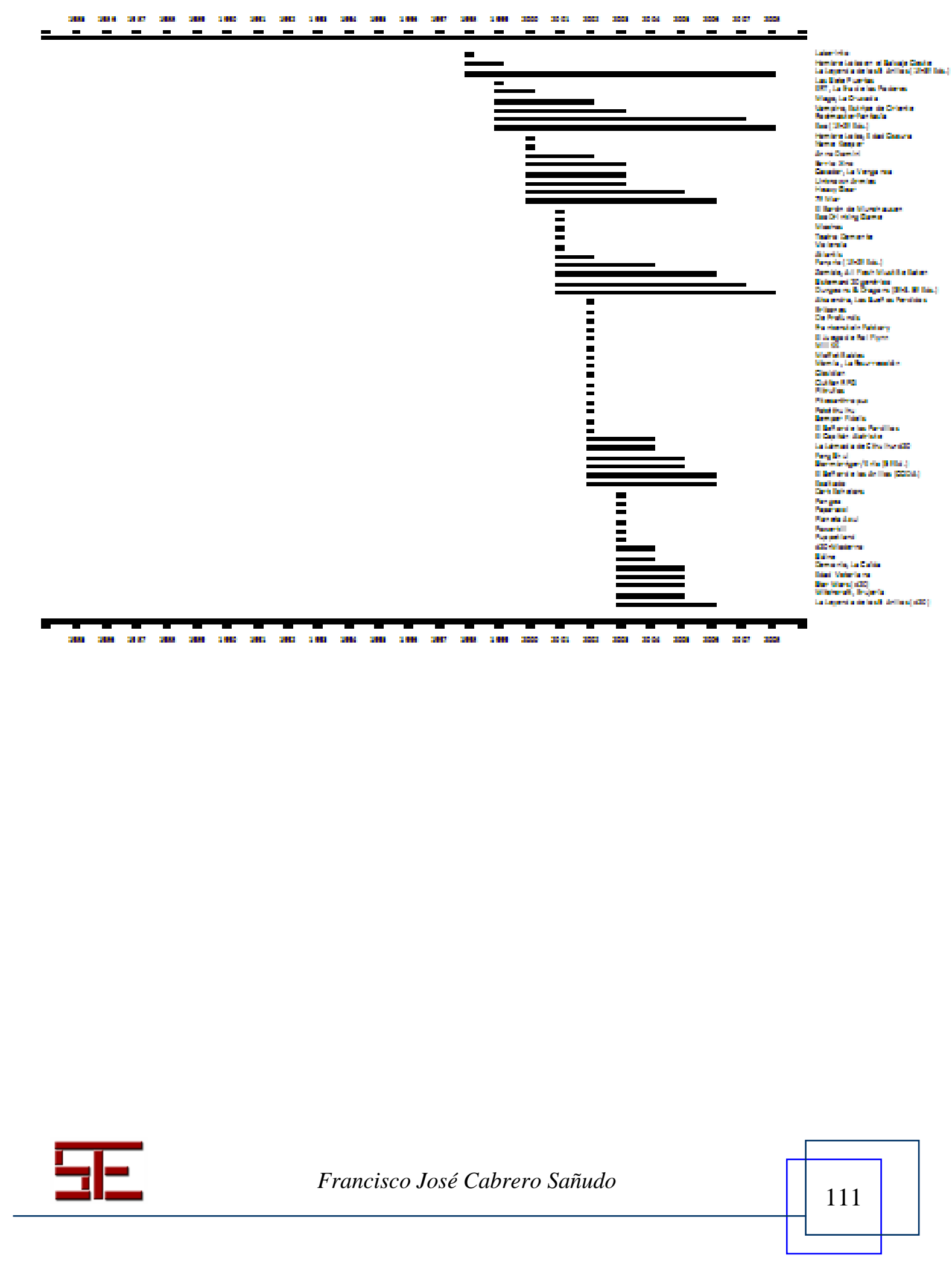

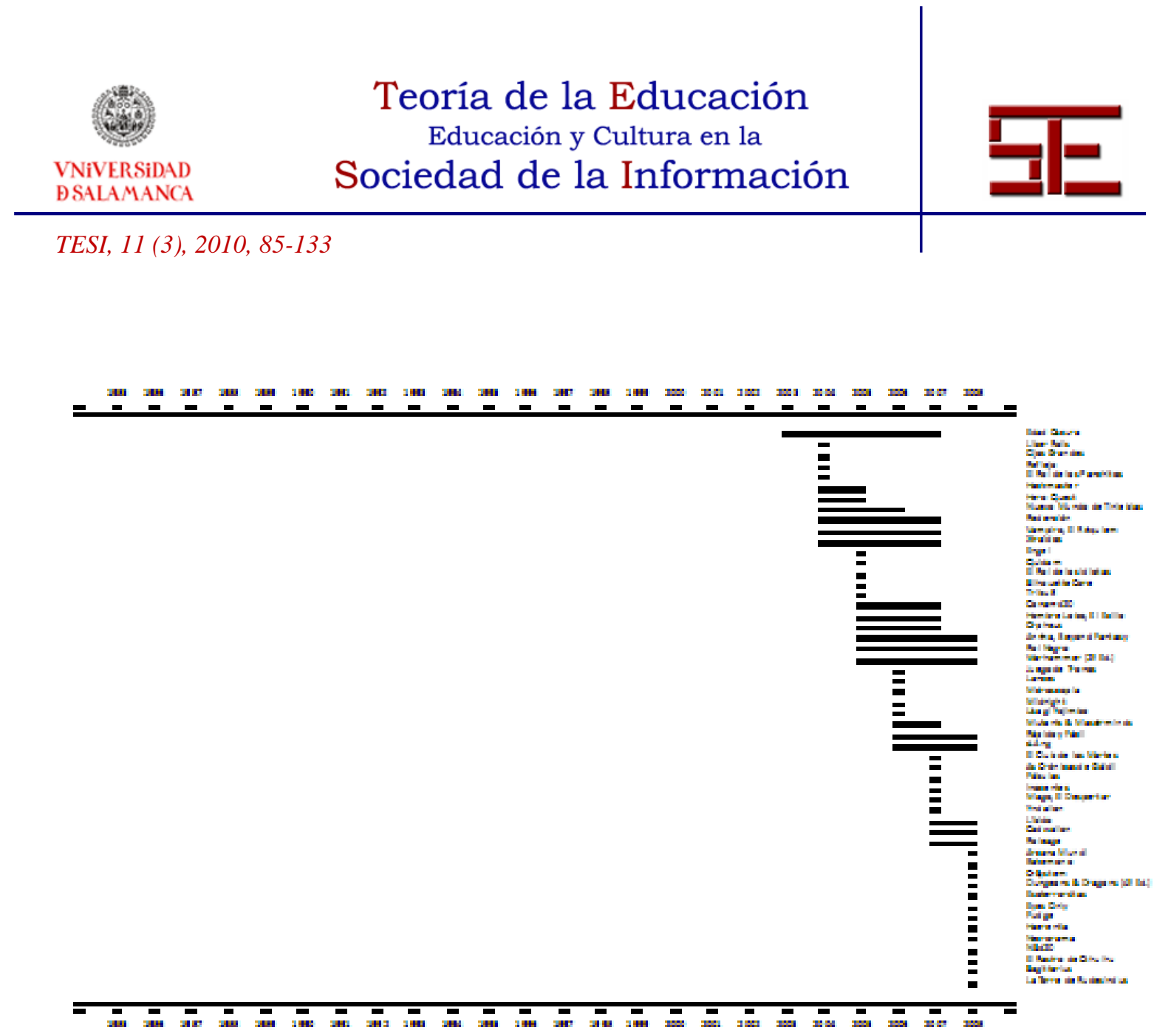

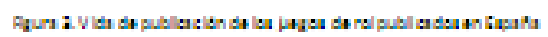

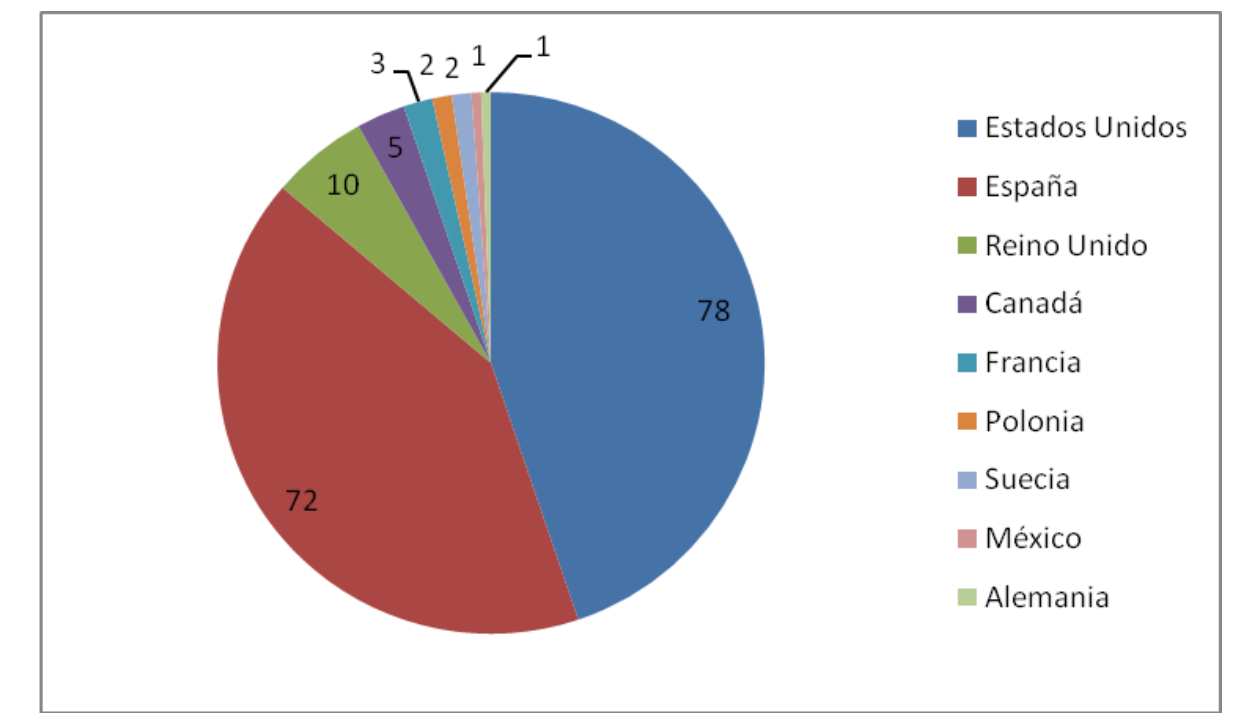

Figura 4. Origen y número de los juegos de rol publicados en España.

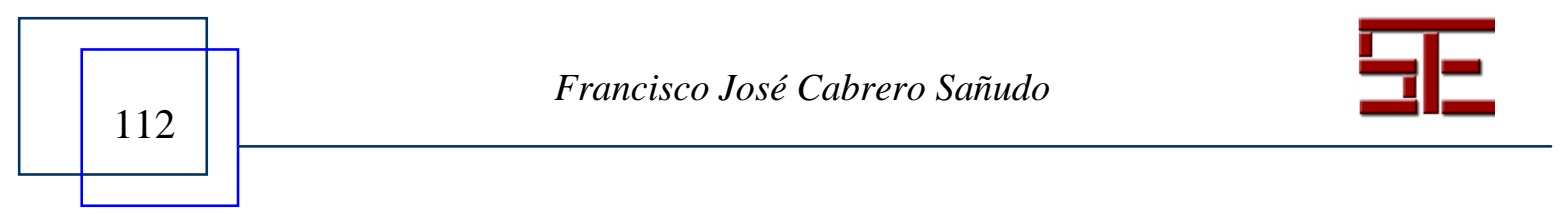



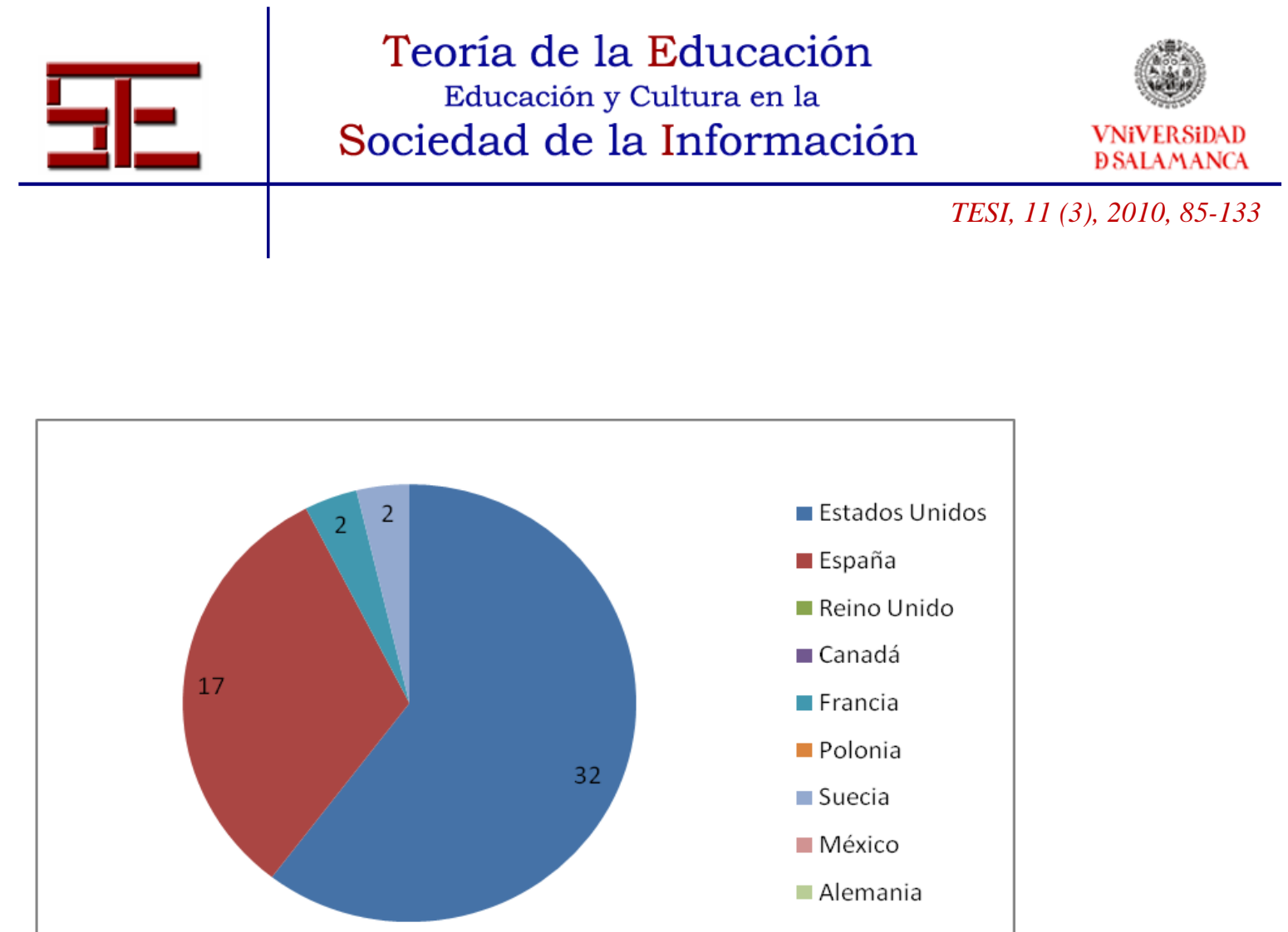

Estados Unidos

España

Reino Unido

- Canadá

- Francia

- Polonia

Suecia

México

Alemania

Figura 5. Origen y número de los juegos de rol publicados en España durante 19851996.

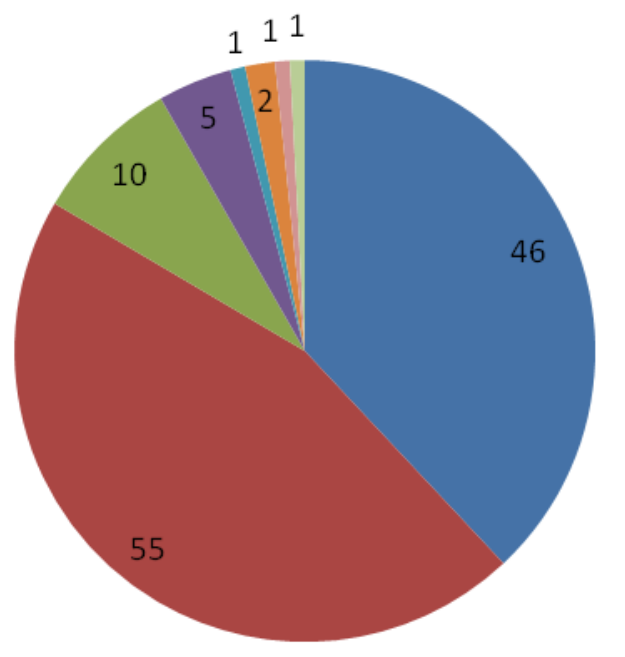

— Estados Unidos
— España
- Reino Unido
— Canadá
- Francia
- Polonia
- Suecia
- México
- Alemania

Figura 6. Origen y número de los juegos de rol publicados en España durante 19972008.

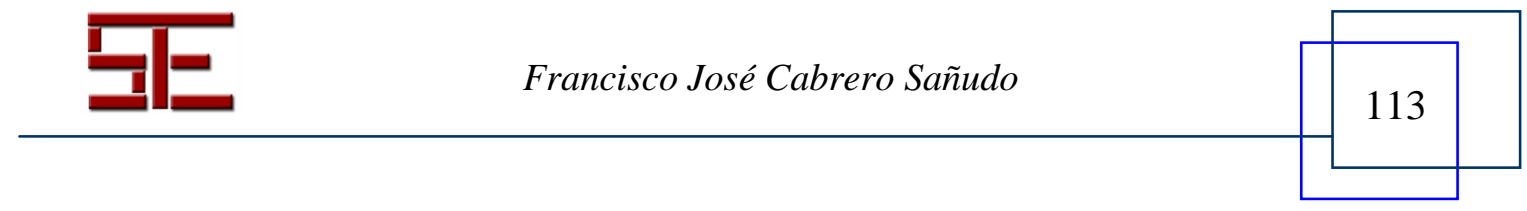



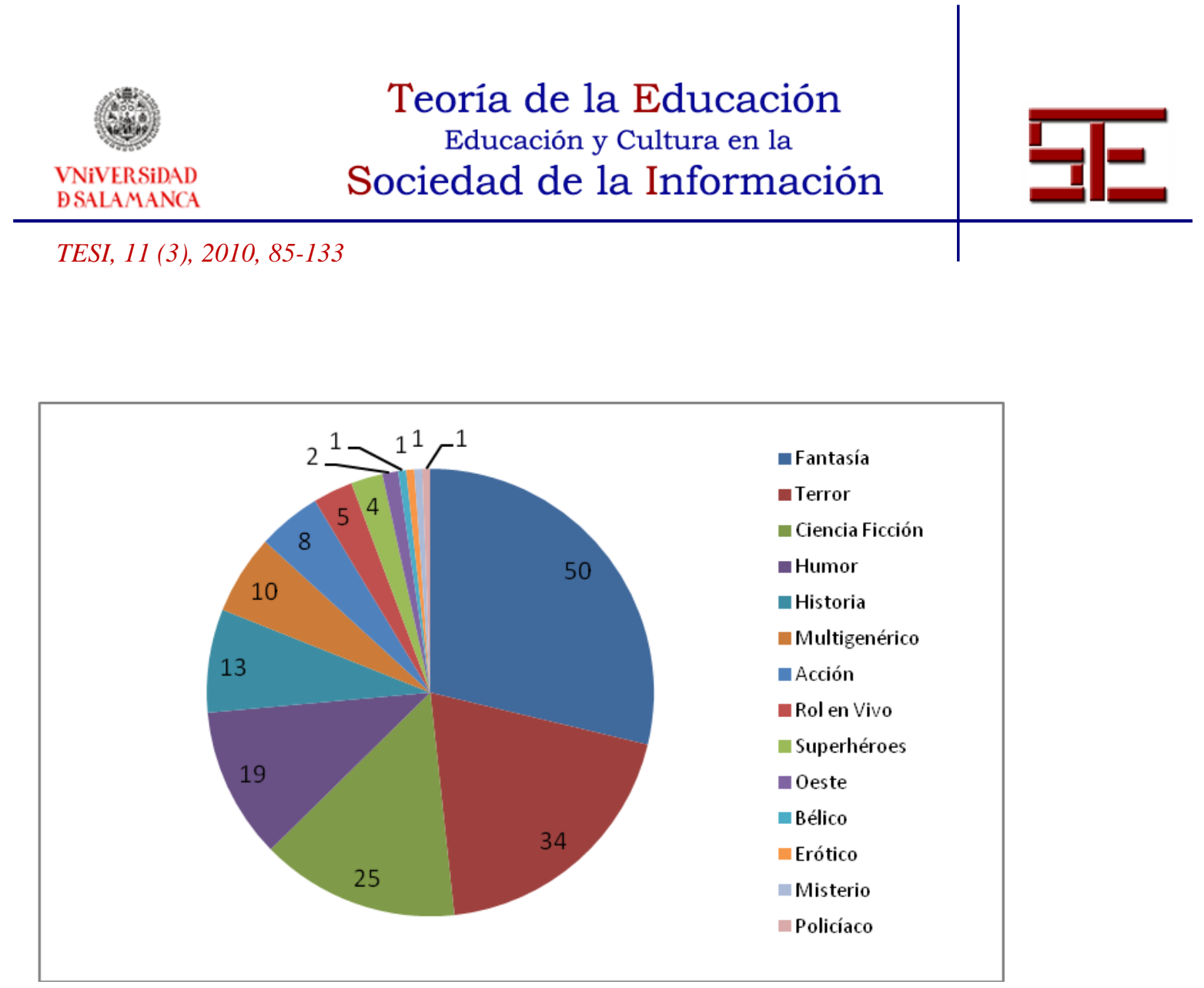

Figura 7. Género y número de los juegos de rol publicados en España.

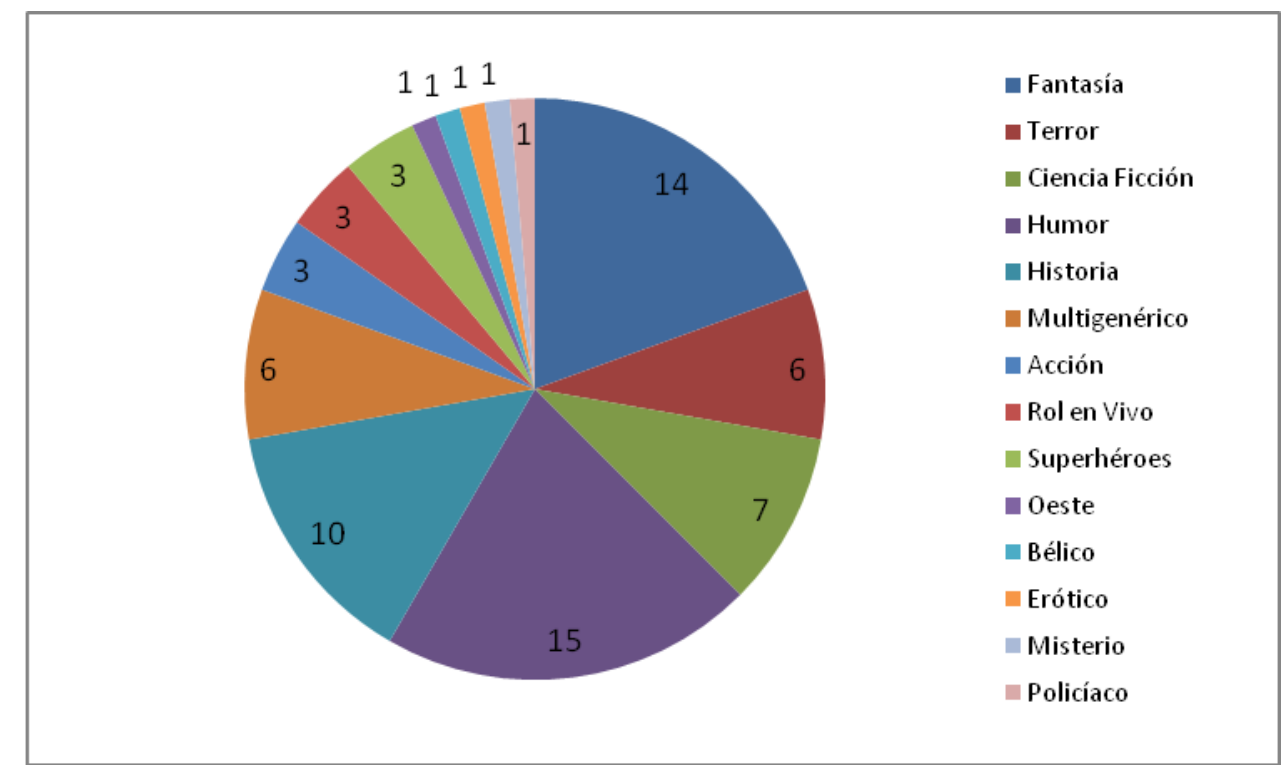

Figura 8. Género y número de los juegos de rol autóctonos publicados en España.

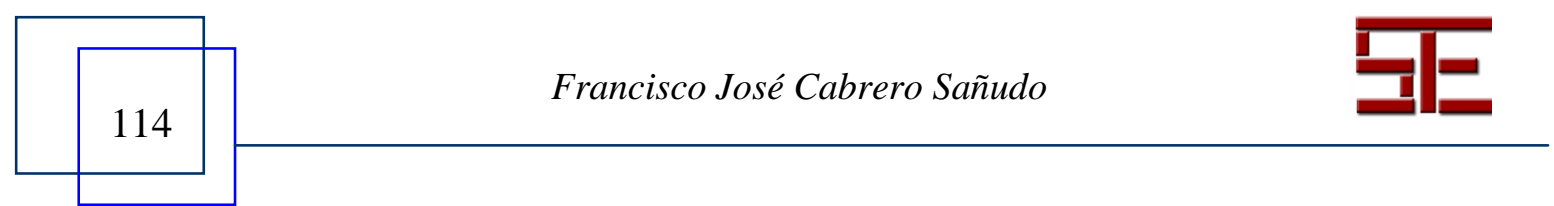



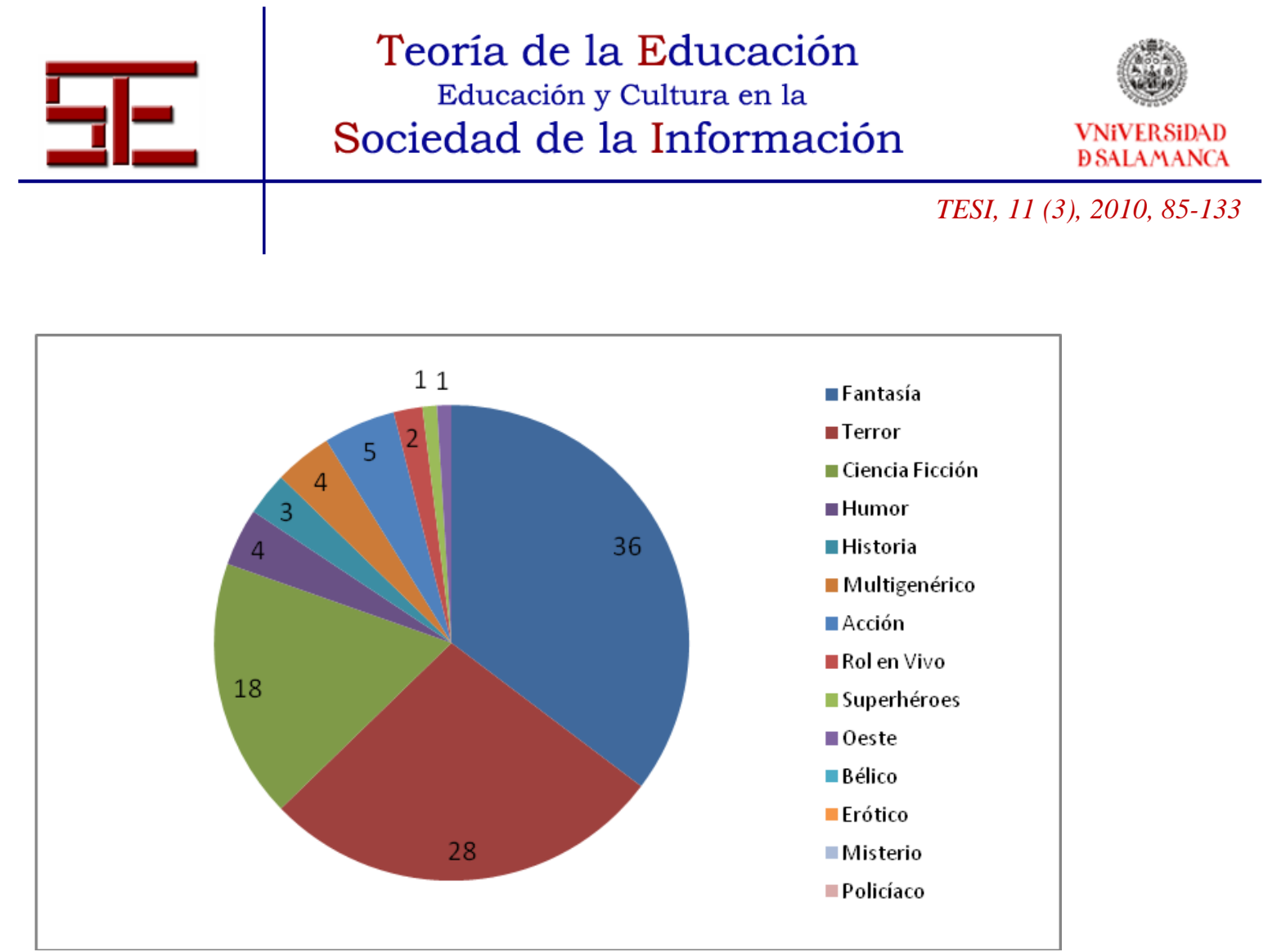

Figura 9. Género y número de los juegos de rol no autóctonos publicados en España.

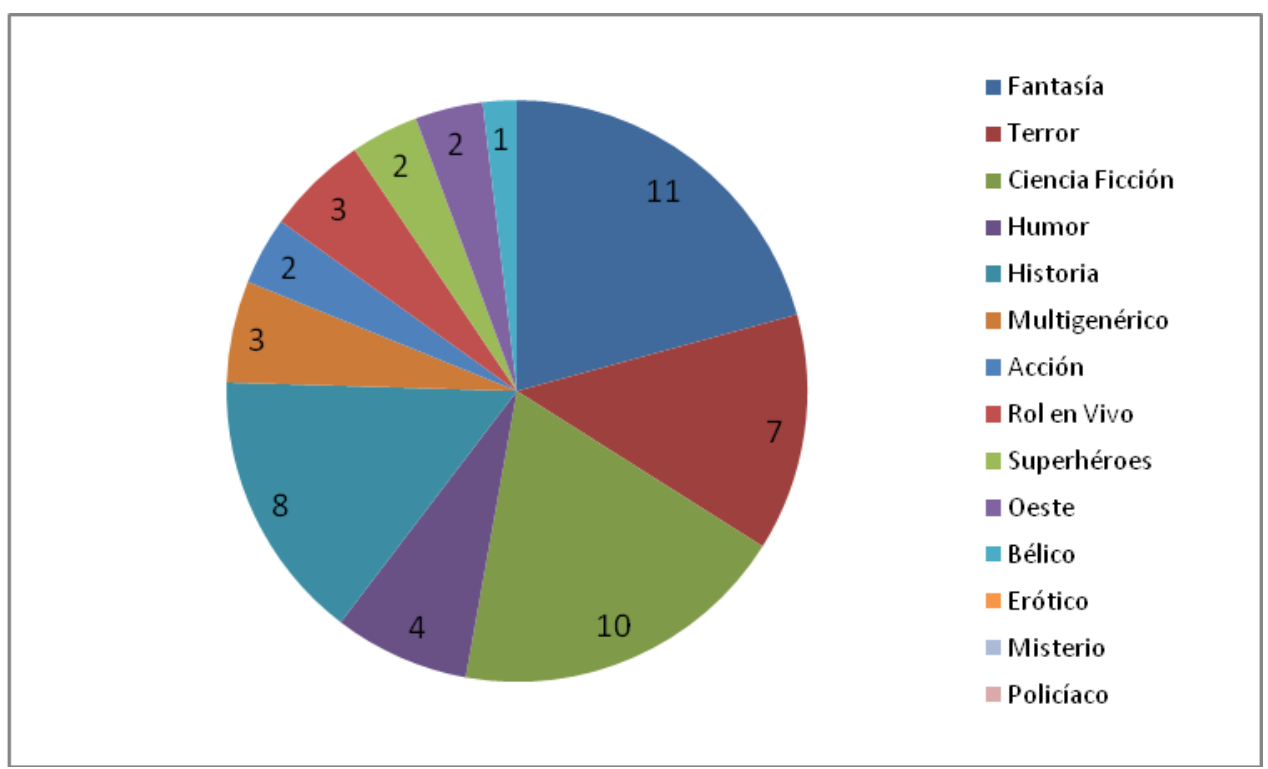

Figura 10. Género y número de los juegos de rol publicados en España durante 19851996.

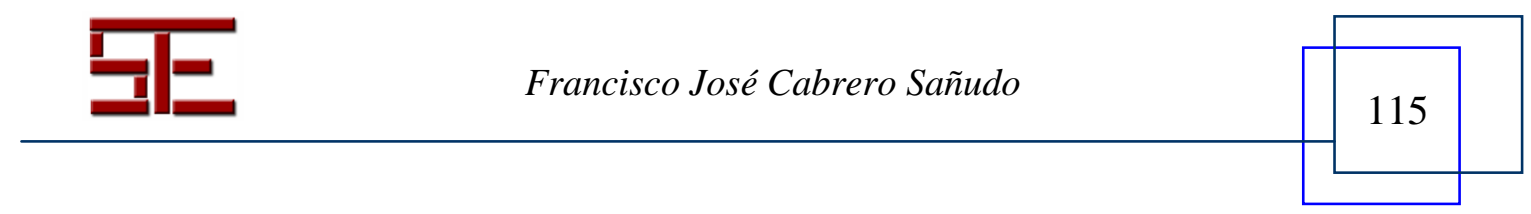



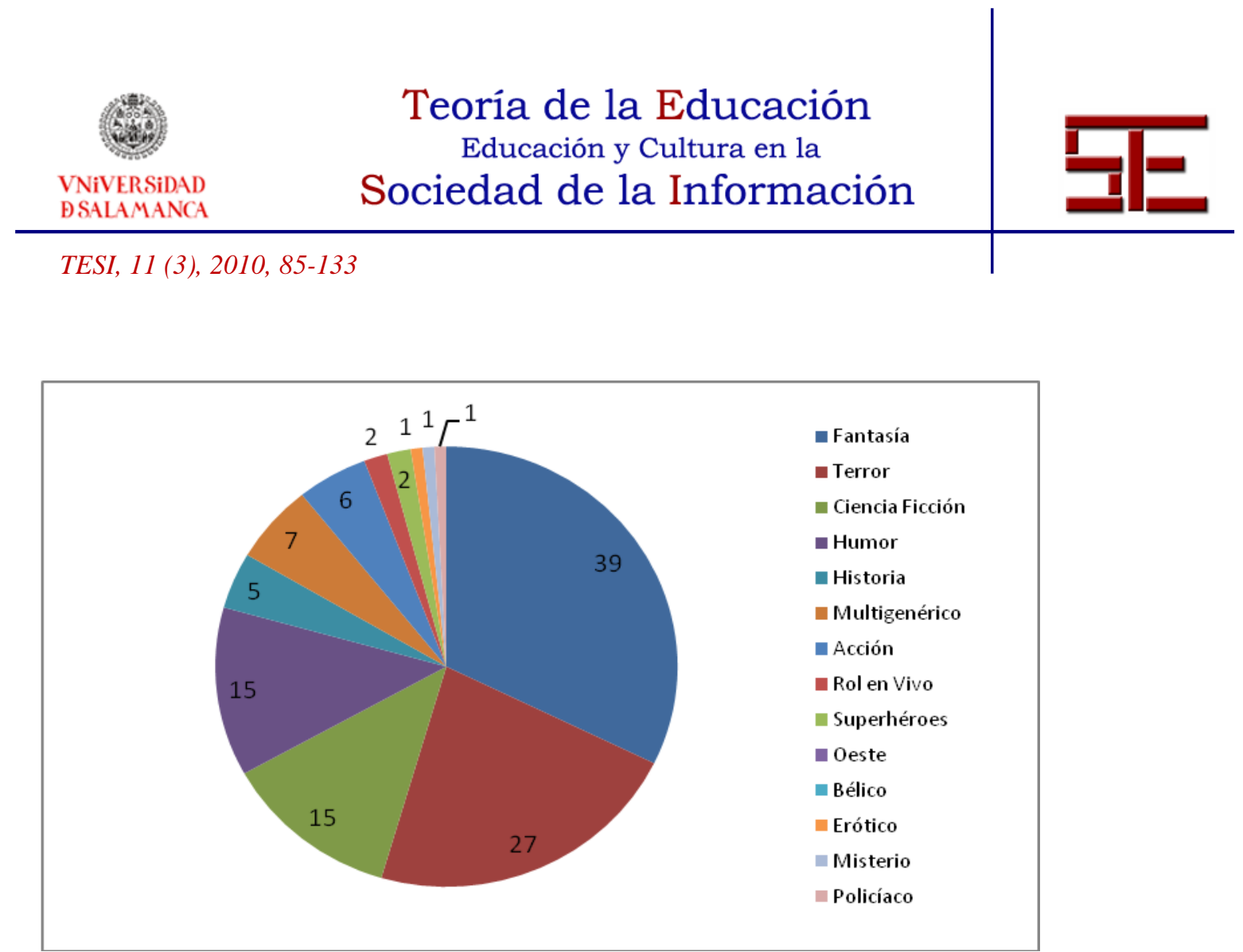

Figura 11. Género y número de los juegos de rol publicados en España durante 19972008.

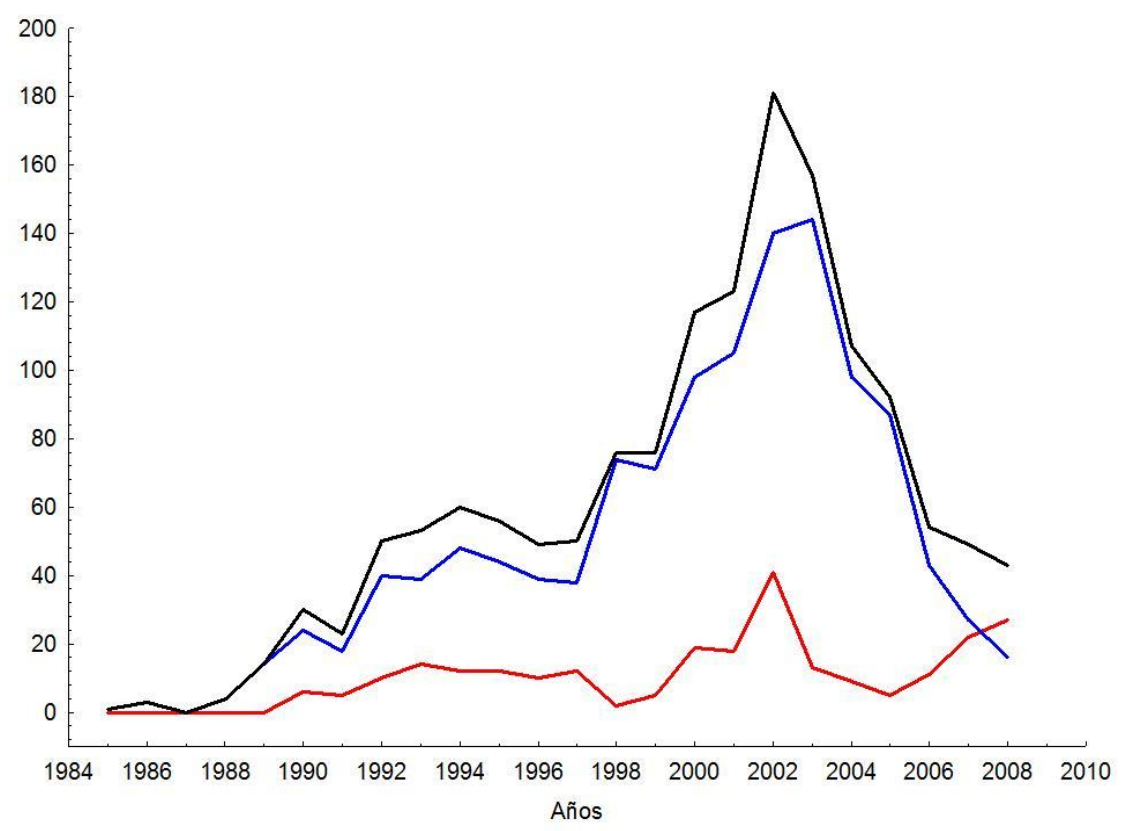

Figura 12. Progresión de aparición de las publicaciones de rol en España. En negro, el número total de publicaciones de rol; en azul, las publicaciones de rol no autóctonas; en rojo, las publicaciones de rol autóctonas.

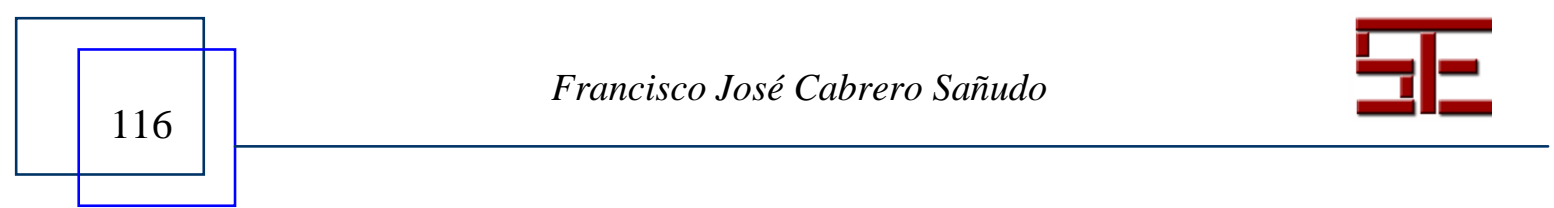



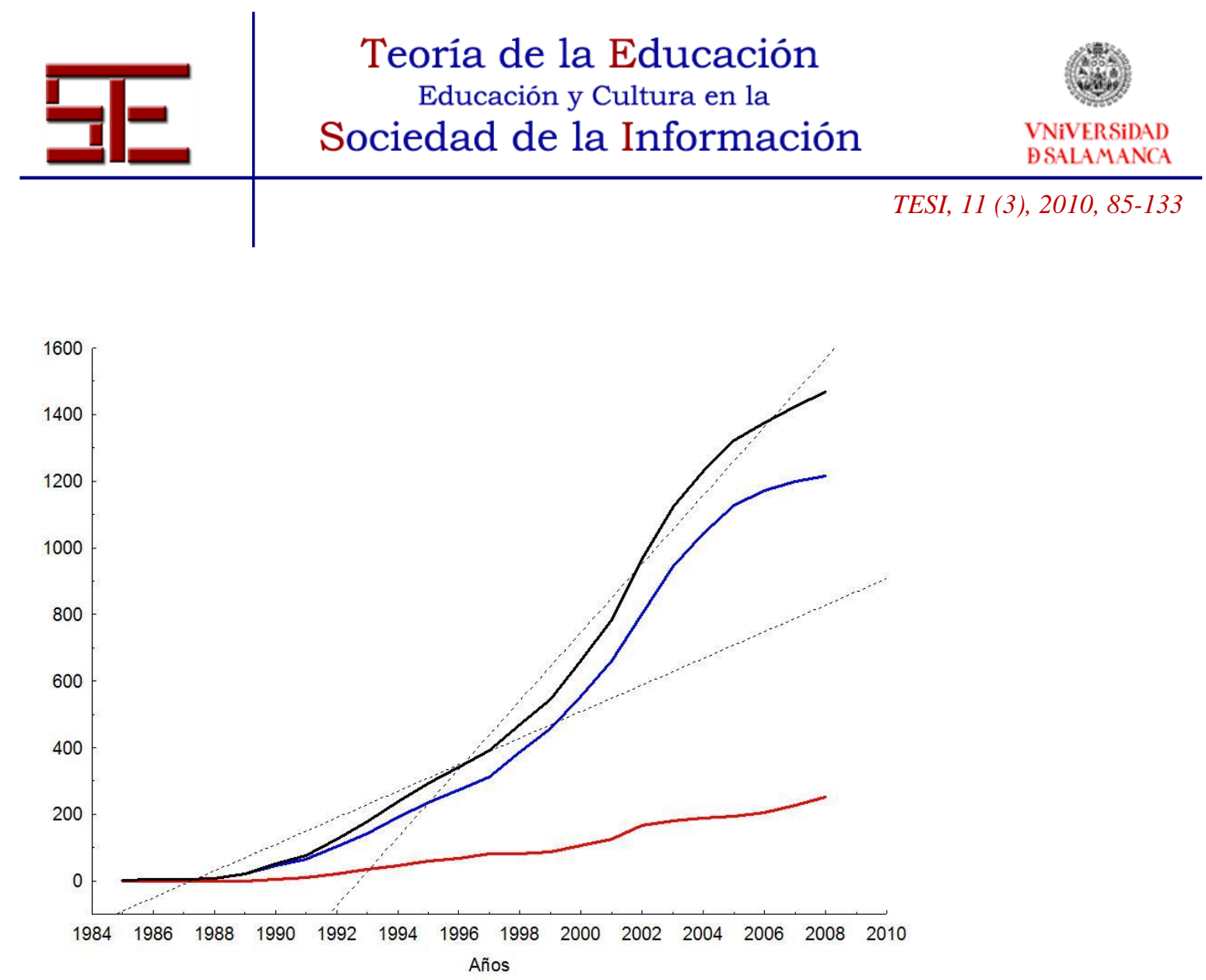

Figura 13. Acumulación de publicaciones de rol en España. En negro, todas las publicaciones de rol; en azul, las publicaciones de rol no autóctonas; en rojo, las publicaciones de rol autóctonas. Las dos funciones representadas con trazos discontinuos representan las dos pendientes diferentes de la curva de publicaciones identificadas por un análisis de estimación no lineal Piecewise lineal regression $\left(\mathrm{p}<0.05 ; \mathrm{R}^{2}=98.84 \%\right)$. Ambas funciones se cruzan entre los años 1996 y 1997, de modo que las dos etapas resultantes consideradas en los diferentes análisis fueron $\mathrm{E}_{1}$ (19851996) y $\mathrm{E}_{2}(1997-2008)$.

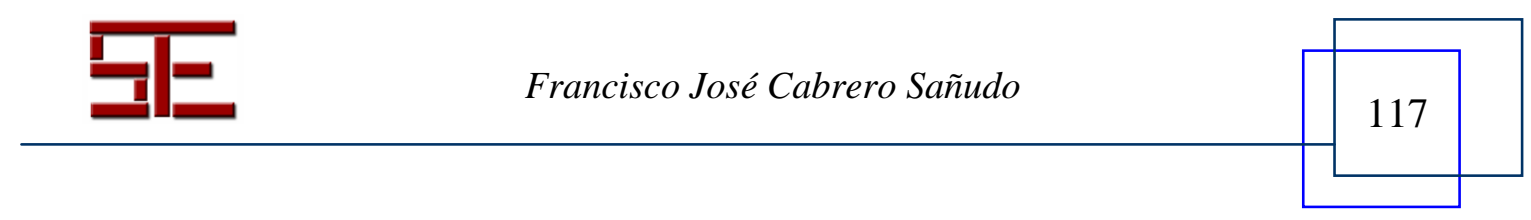



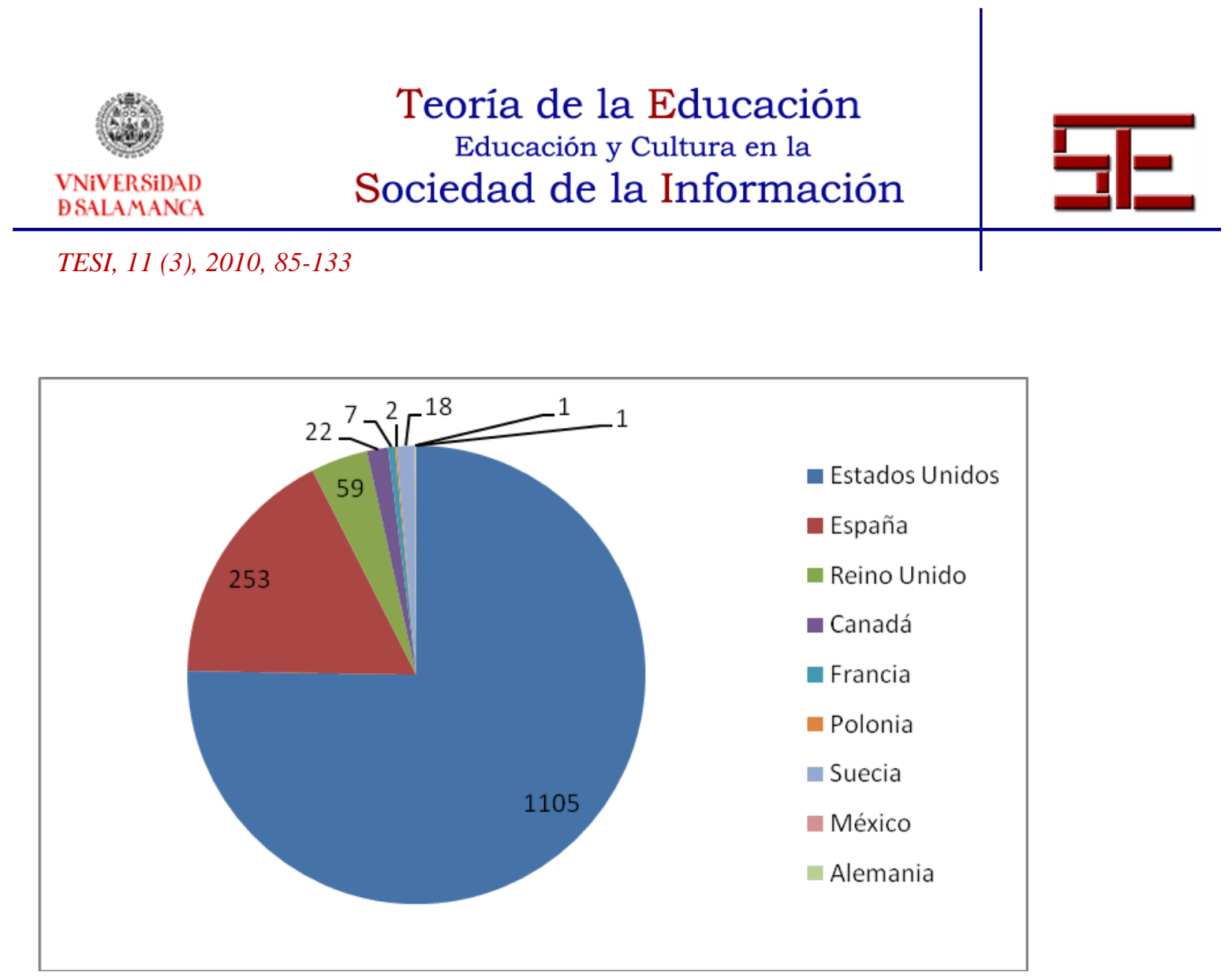

Figura 14. Origen y número de las publicaciones de rol en España.

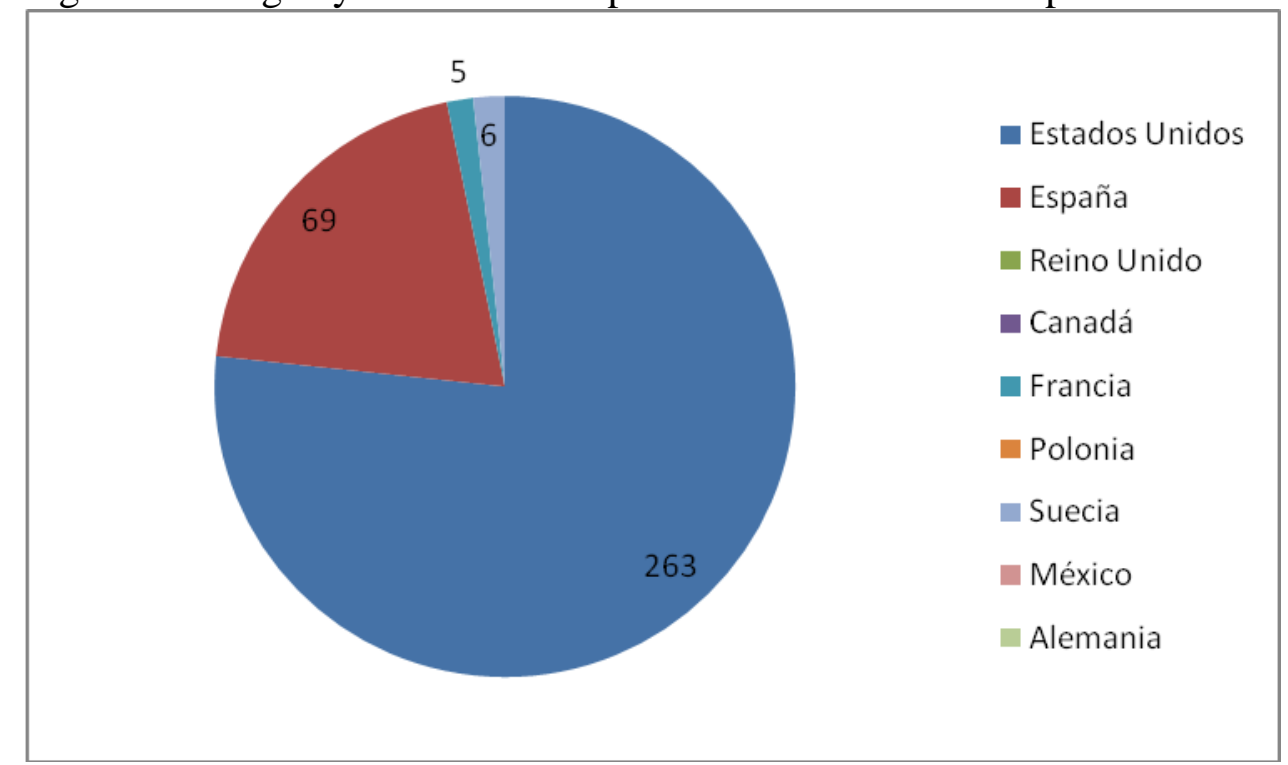

Figura 15. Origen y número de las publicaciones de rol en España durante 1985-1996.

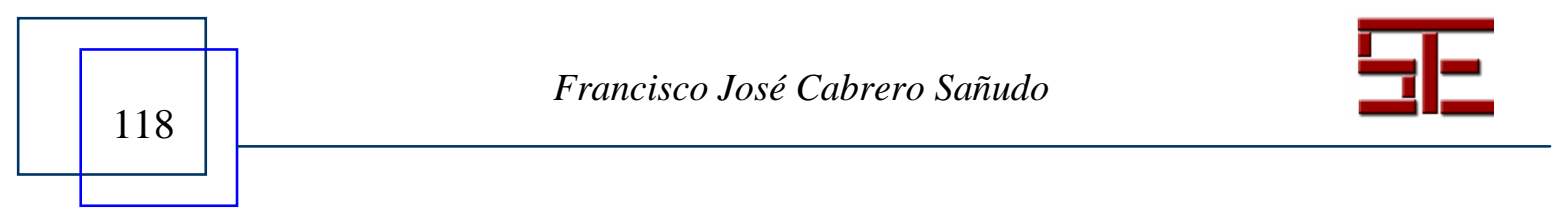



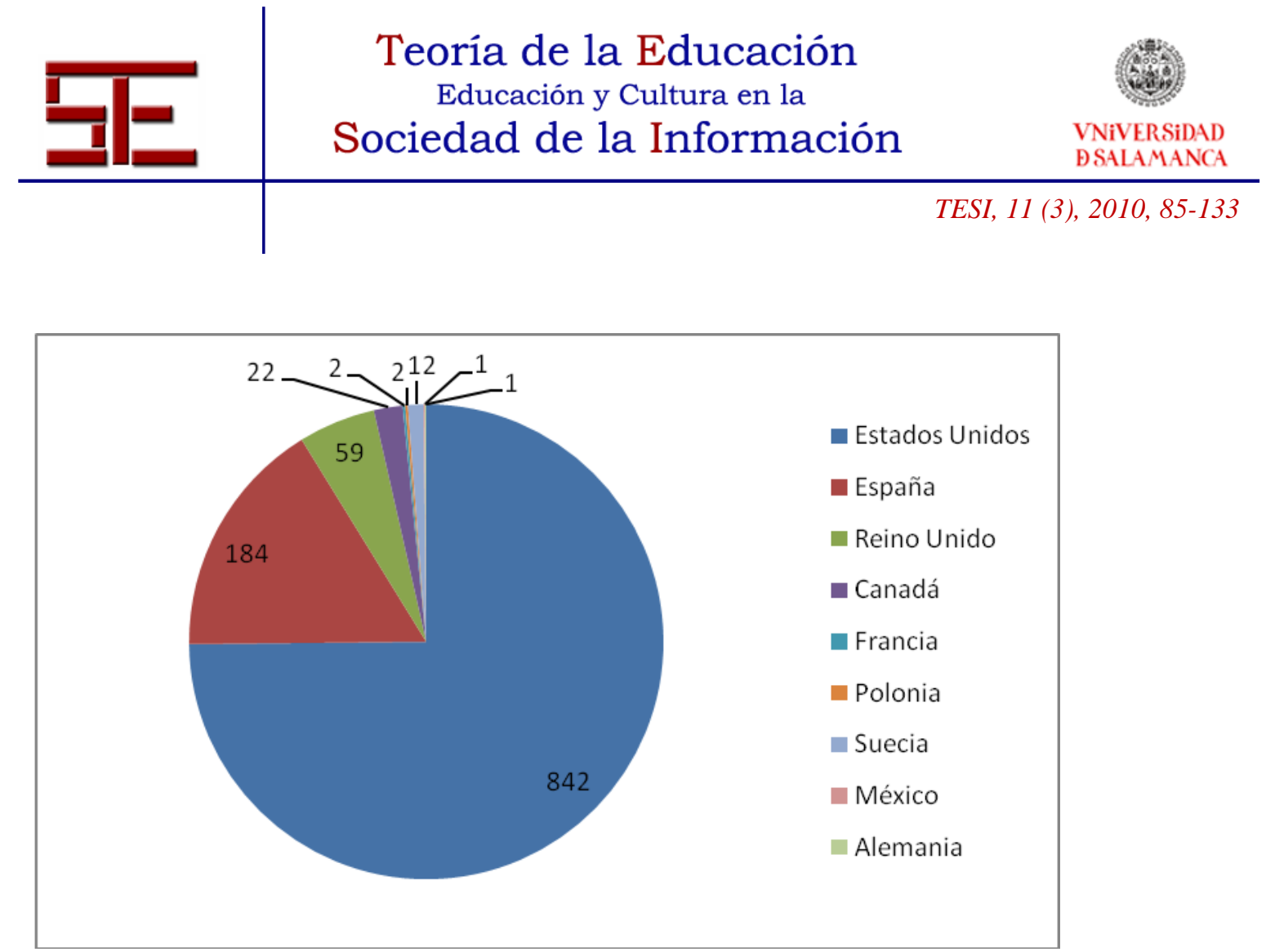

Figura 16. Origen y número de las publicaciones de rol en España durante 1997-2008.

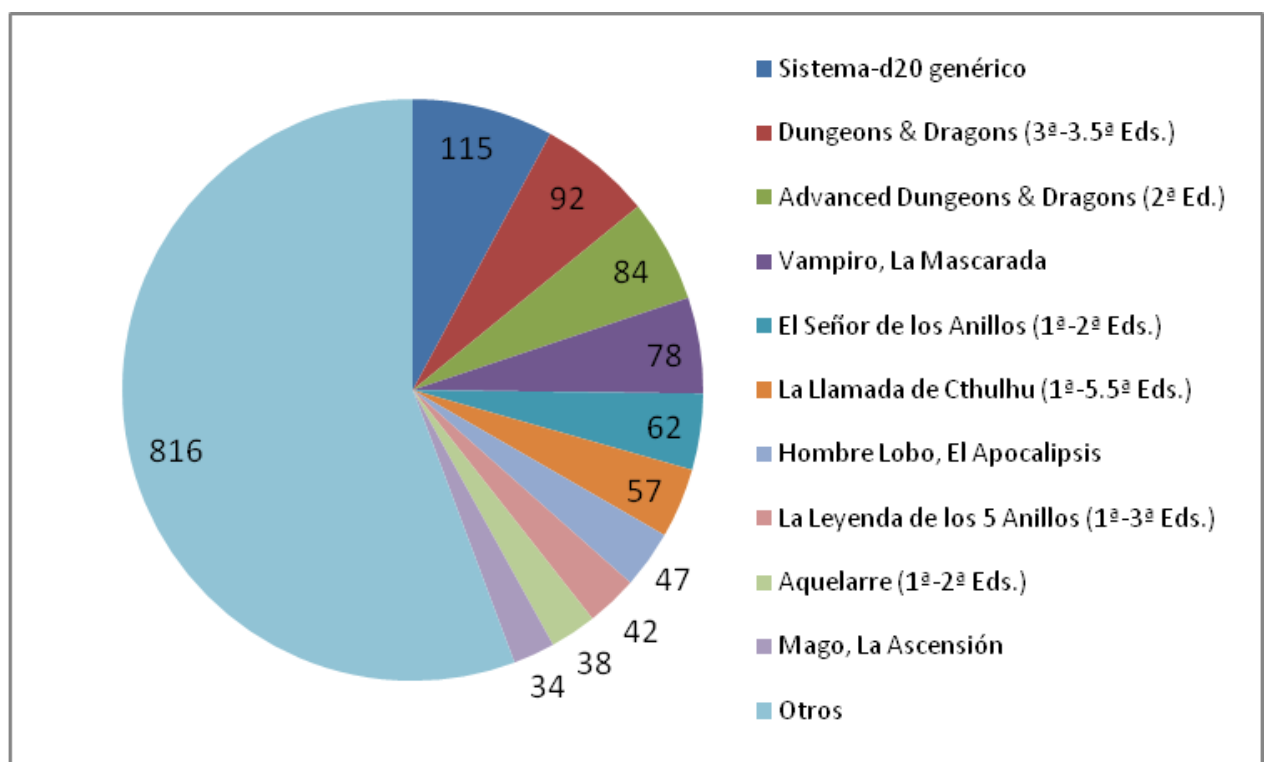

Figura 17. Distribución de publicaciones de rol en España según los juegos de rol correspondientes.

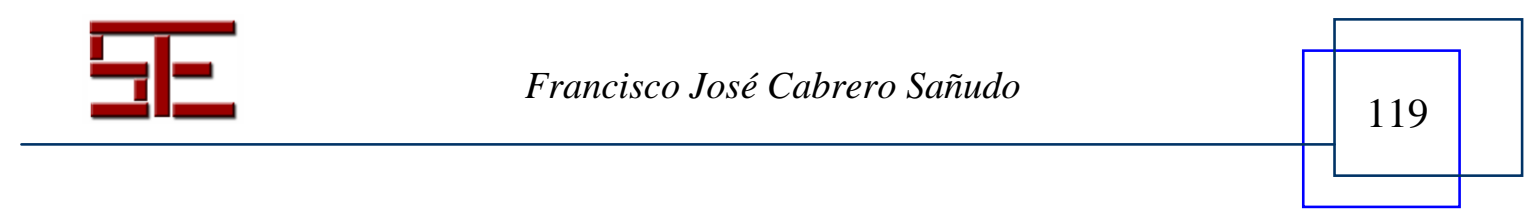



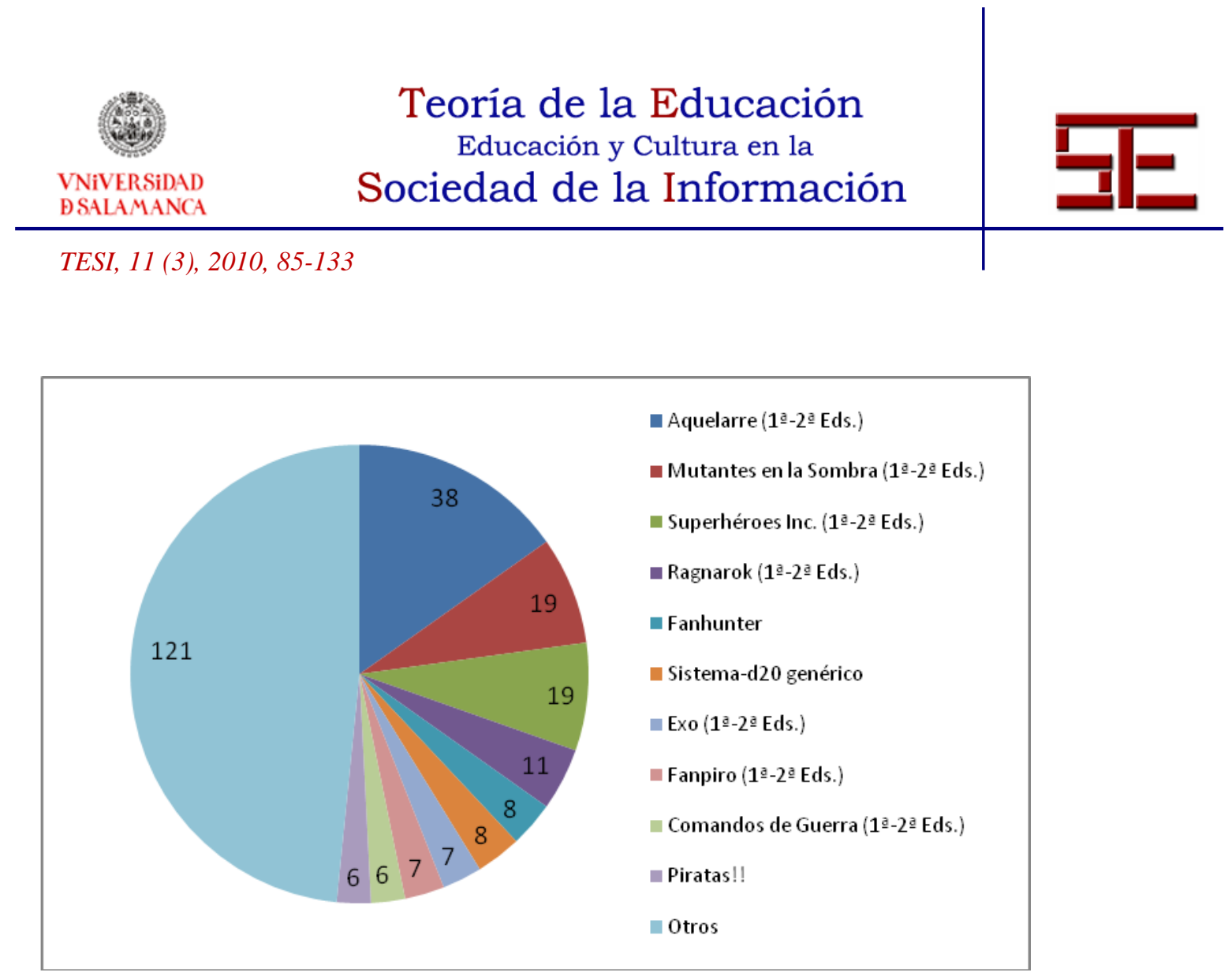

Figura 18. Distribución de publicaciones autóctonas de rol en España según los juegos de rol correspondientes.

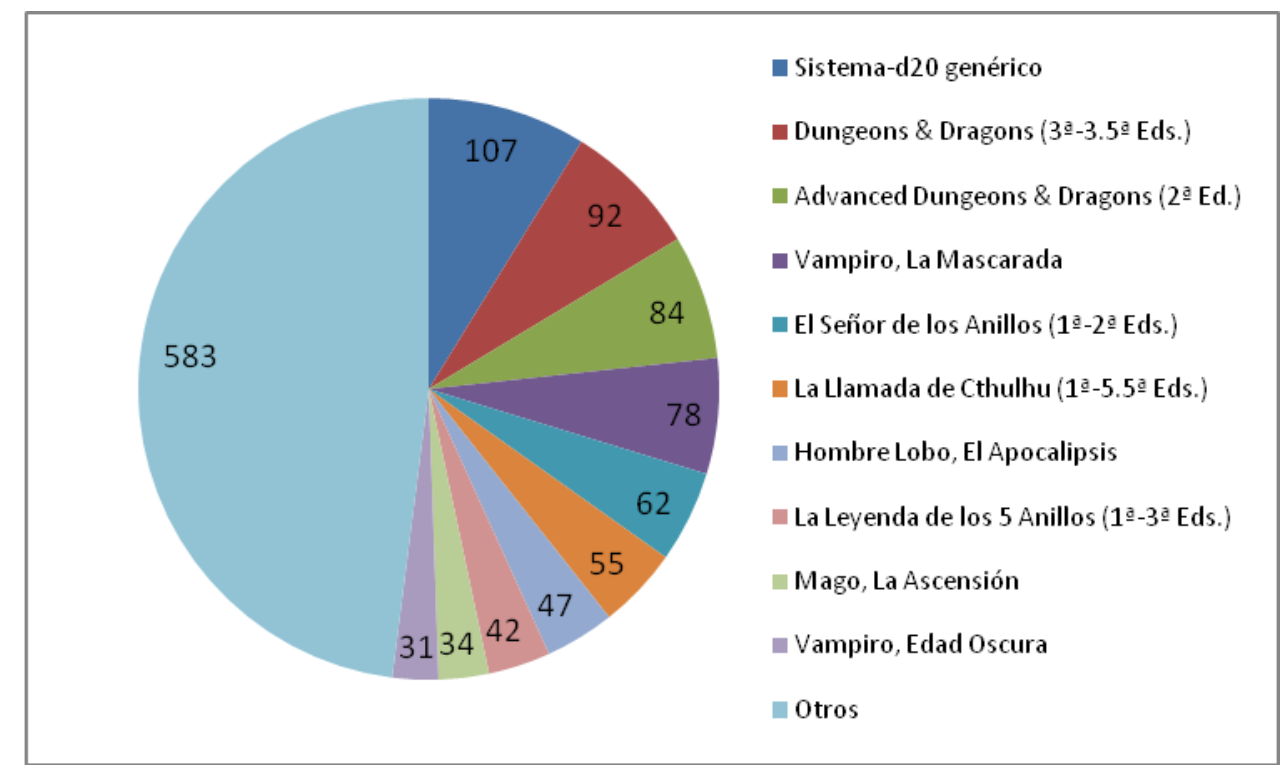

Figura 19. Distribución de publicaciones no autóctonas de rol en España según los juegos de rol correspondientes.

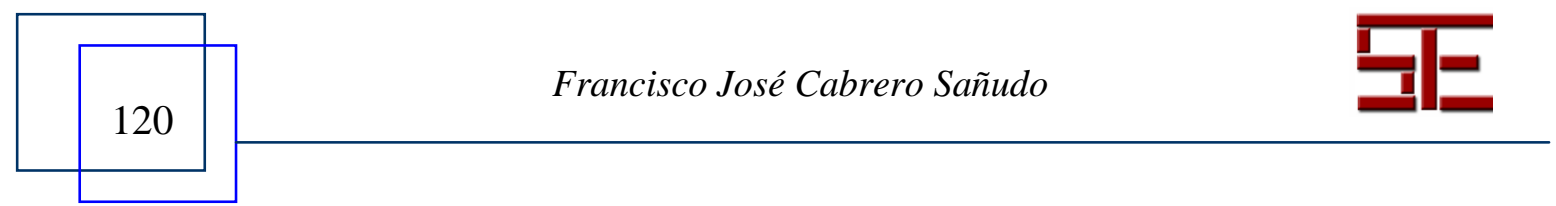



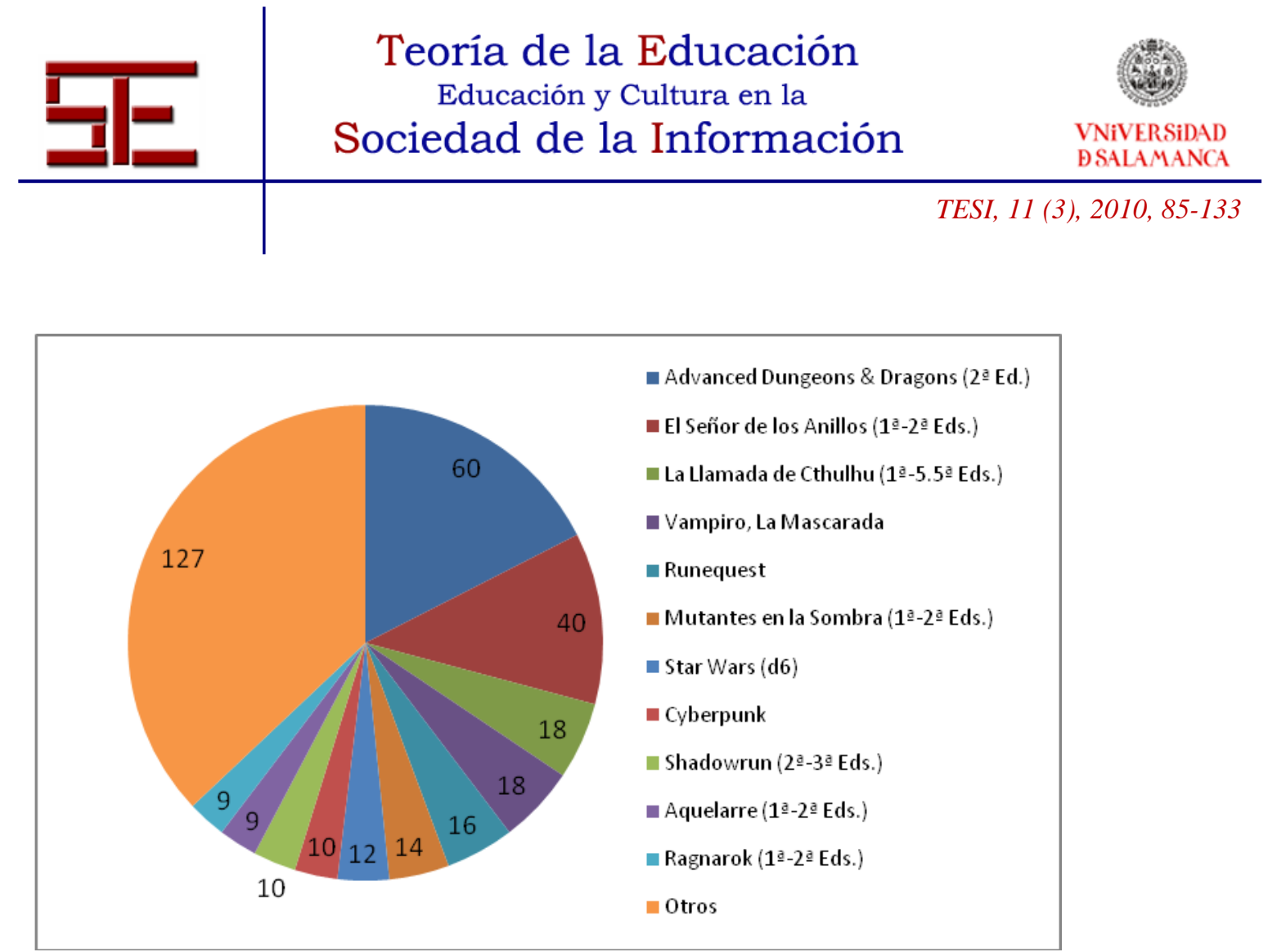

Figura 20. Distribución de publicaciones de rol en España según los juegos de rol correspondientes durante 1985-1996.

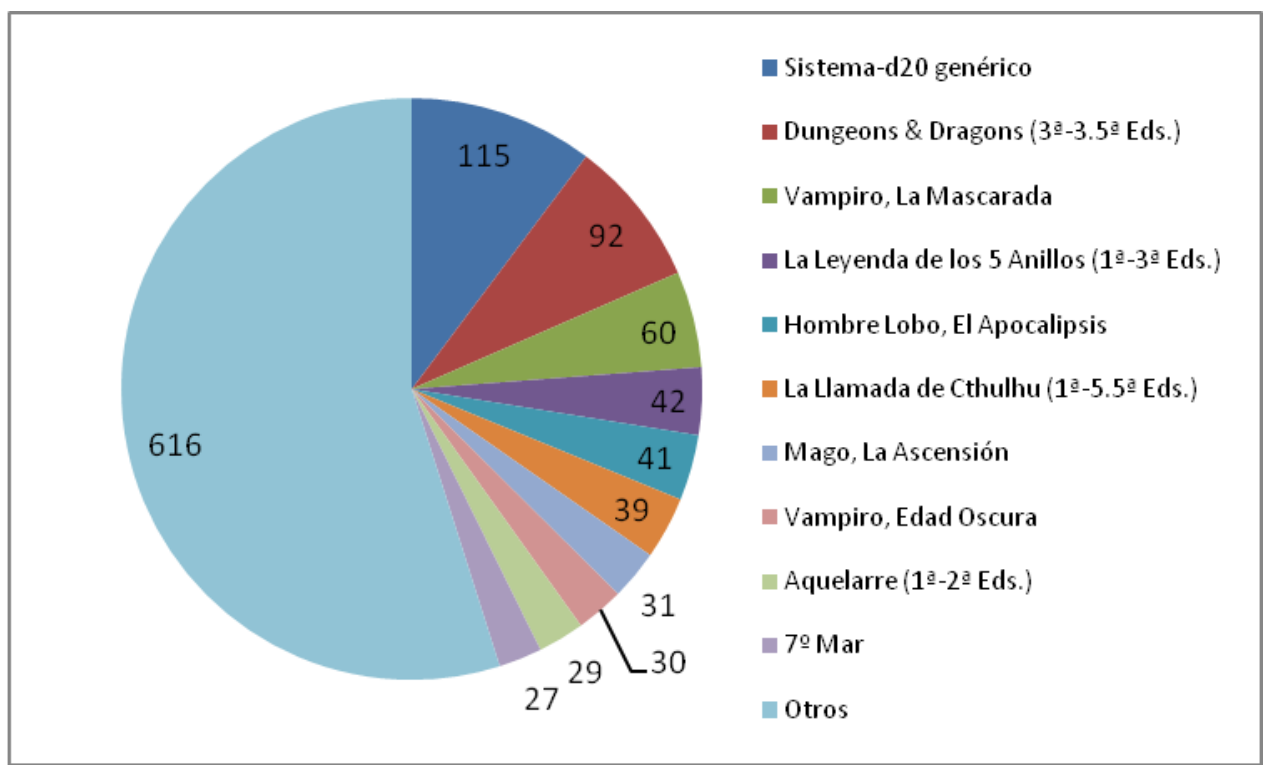

Figura 21. Distribución de publicaciones de rol en España según los juegos de rol correspondientes durante 1997-2008.

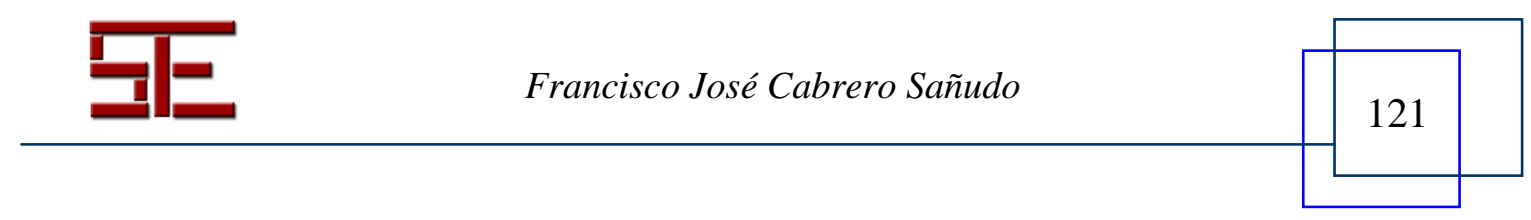




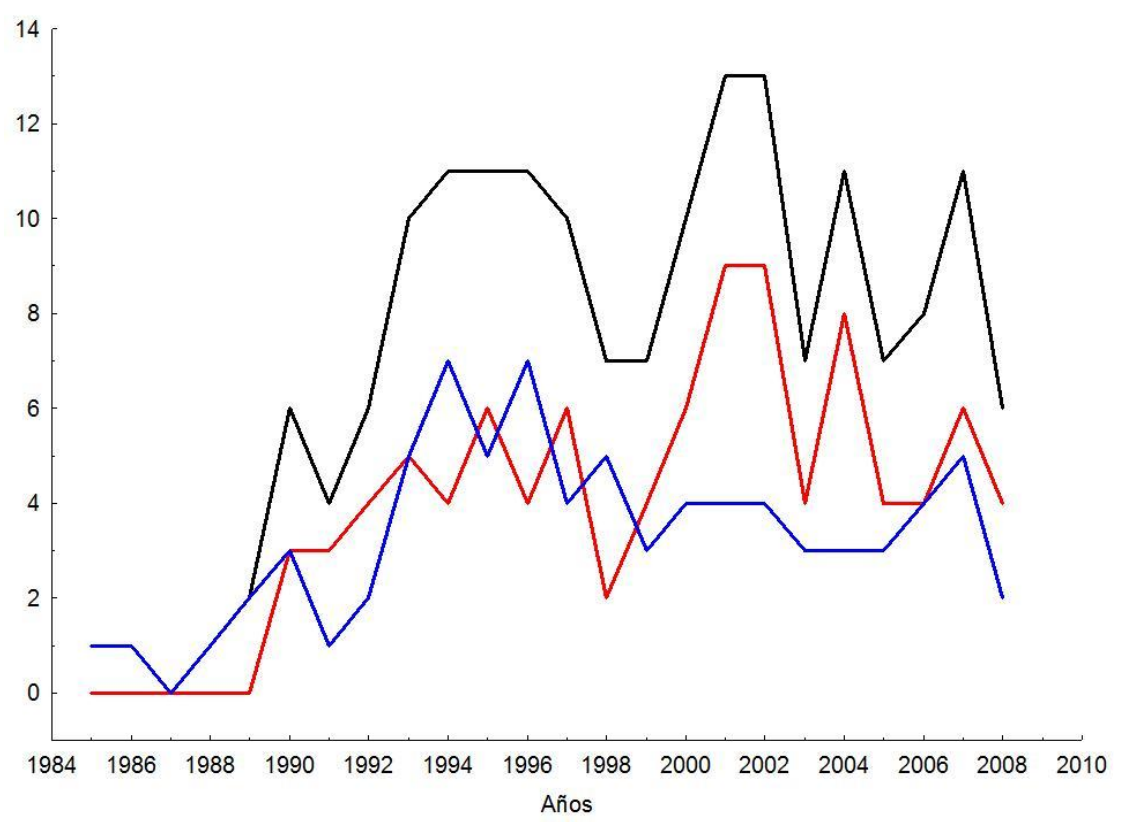

Figura 22. Progresión de aparición de las editoriales de rol en España. En negro, el número total de editoriales de rol; en azul, las editoriales que publican productos de rol no autóctonos; en rojo, las editoriales que publican productos de rol autóctonos. 

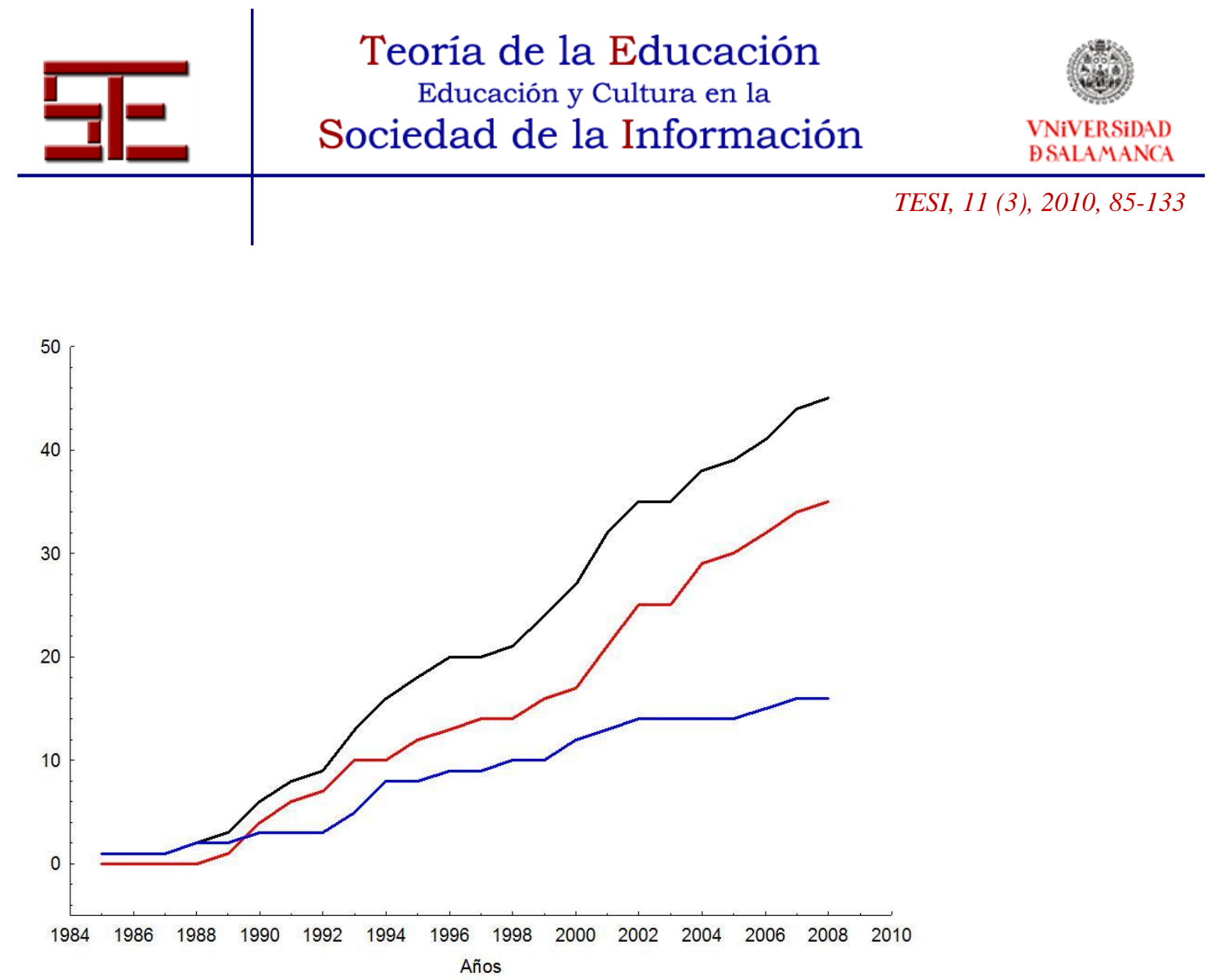

Figura 23. Acumulación de editoriales de rol en España. En negro, el número total de editoriales de rol; en azul, las editoriales que publican productos de rol no autóctonos; en rojo, las editoriales que publican productos de rol autóctonos.

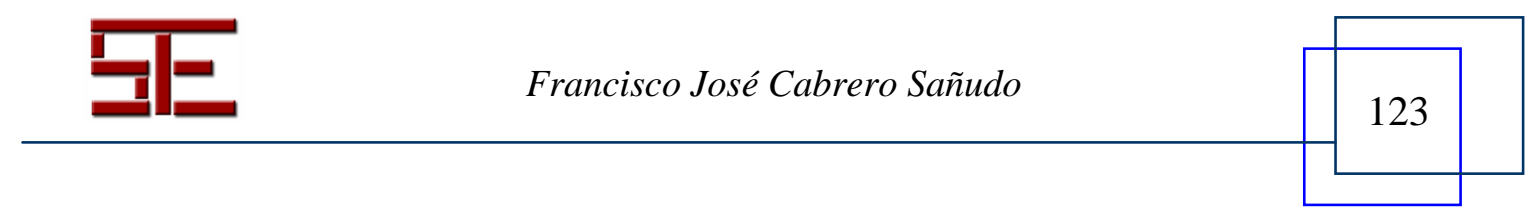




\begin{tabular}{ccc}
$\begin{array}{c}\text { Teoría de la Educación } \\
\text { Educación y Cultura en la } \\
\text { VNiVERSIDAD } \\
\text { BSALAMANCA }\end{array}$ & Sociedad de la Información \\
\hline TESI, $11(3), 2010,85-133$ &
\end{tabular}

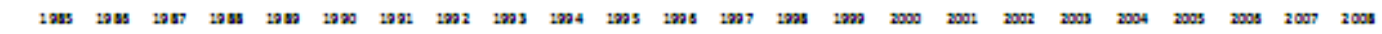

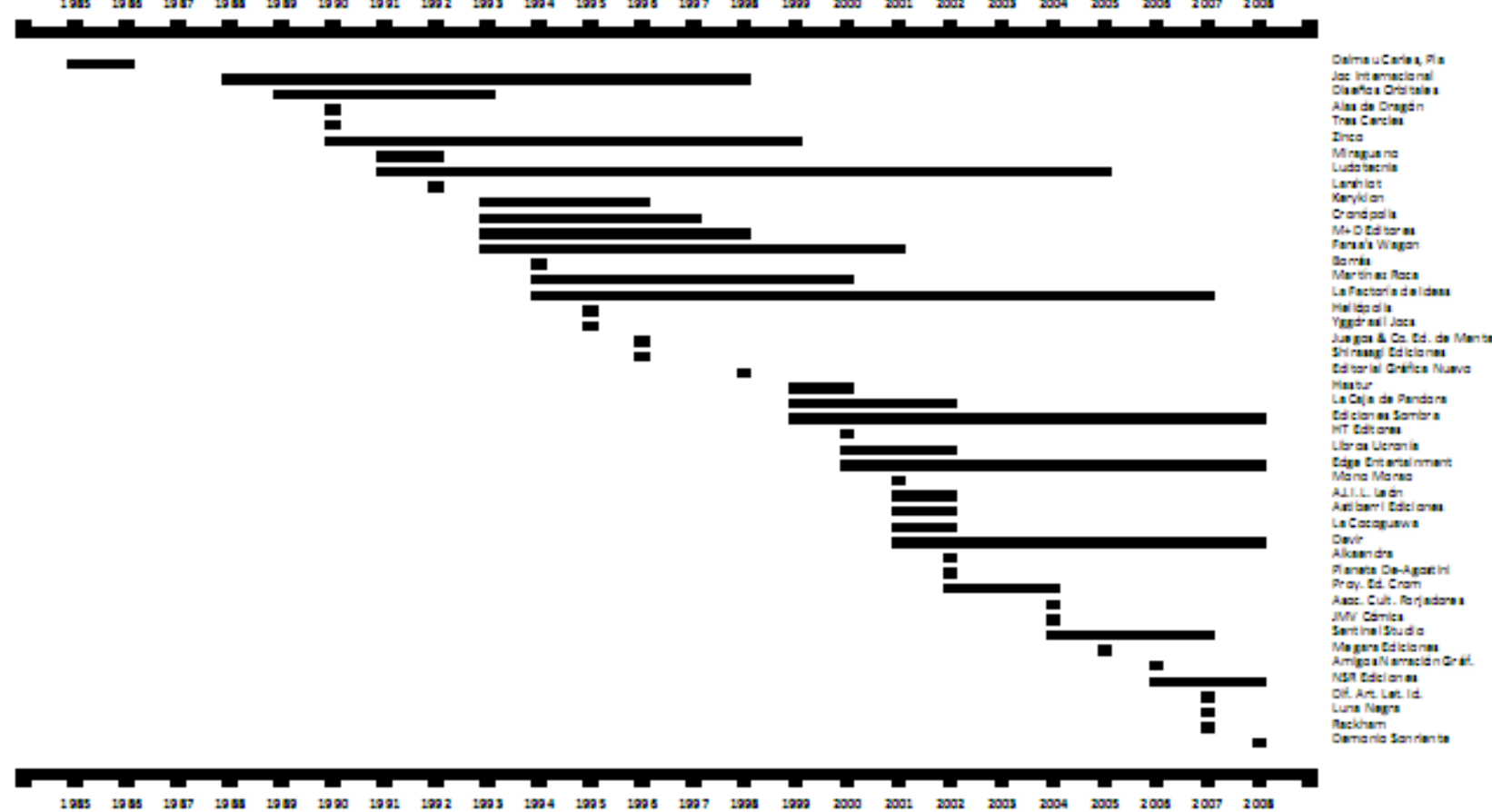

Figura 24. Vida de publ caeion de as editoriales de rol en Espata 

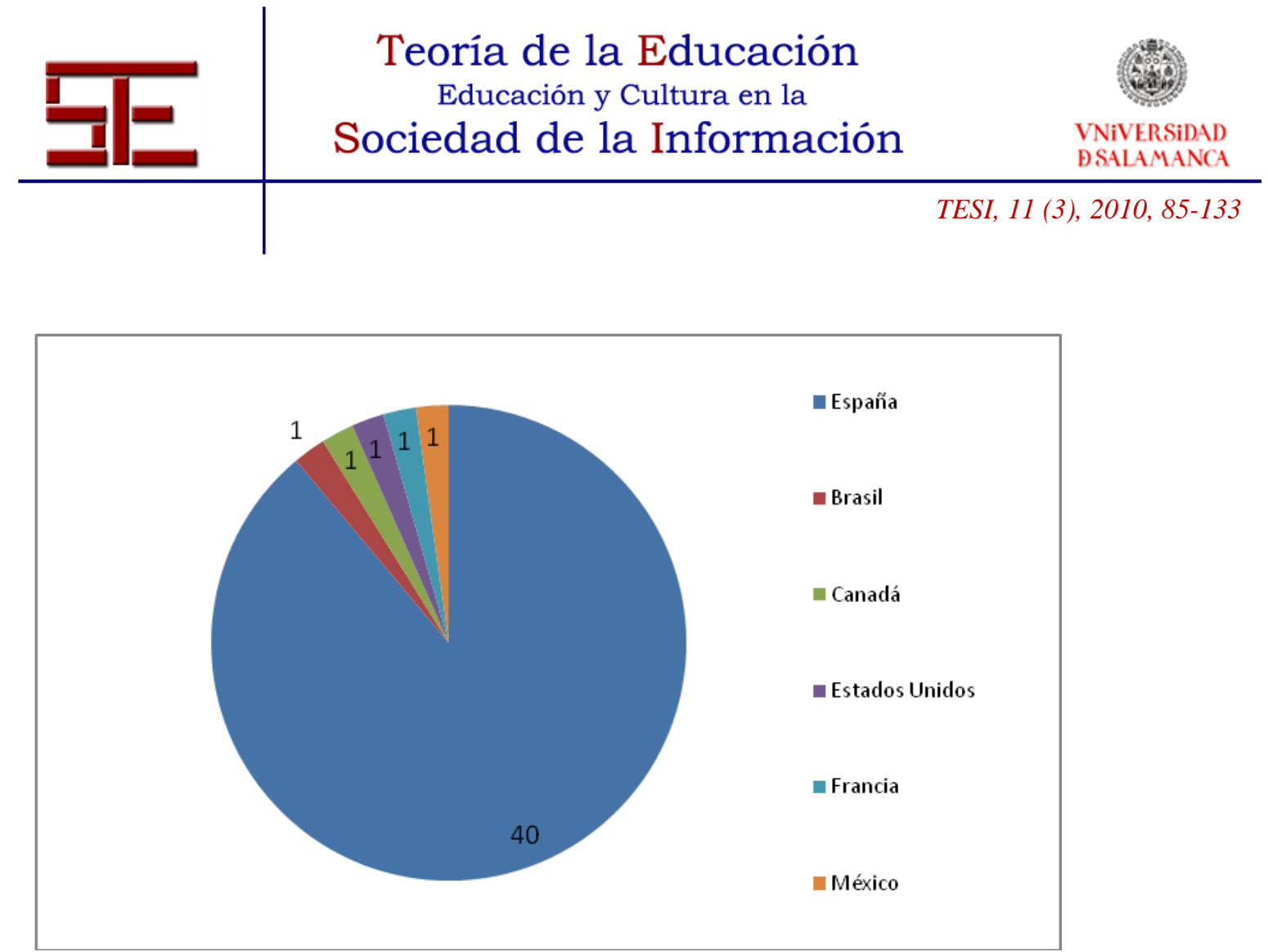

Figura 25. Origen y número de las editoriales de rol en España.

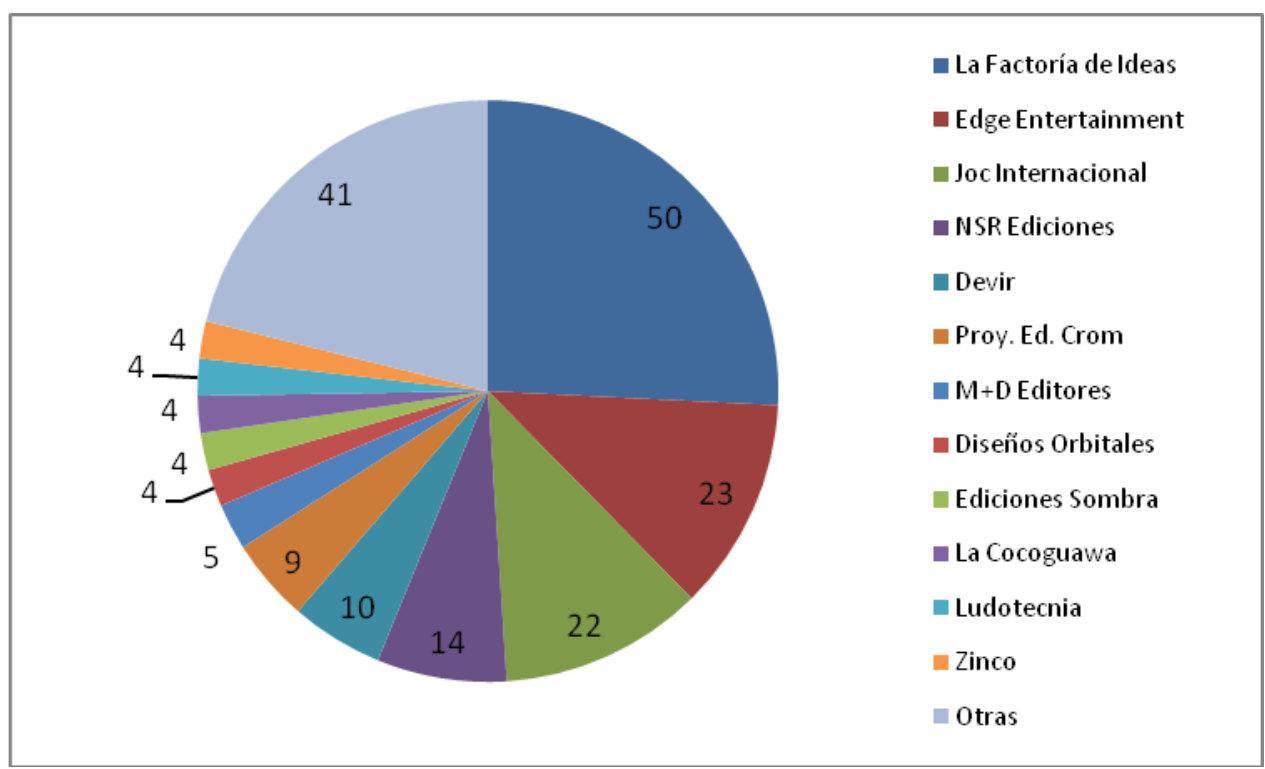

Figura 26. Distribución de editoriales de rol en España según el número de juegos para los que han realizado publicaciones.

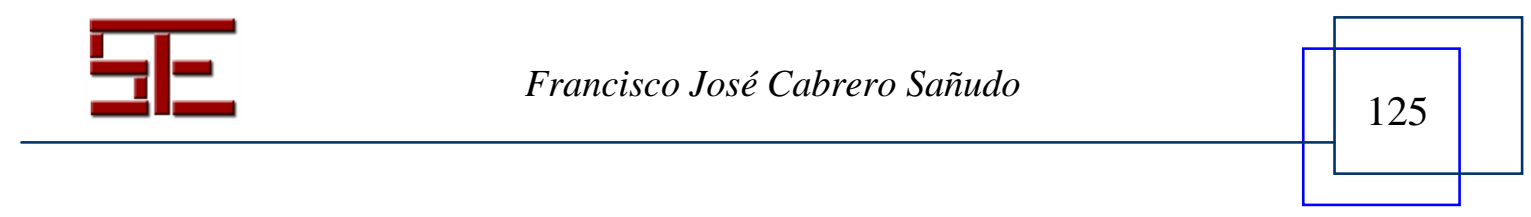



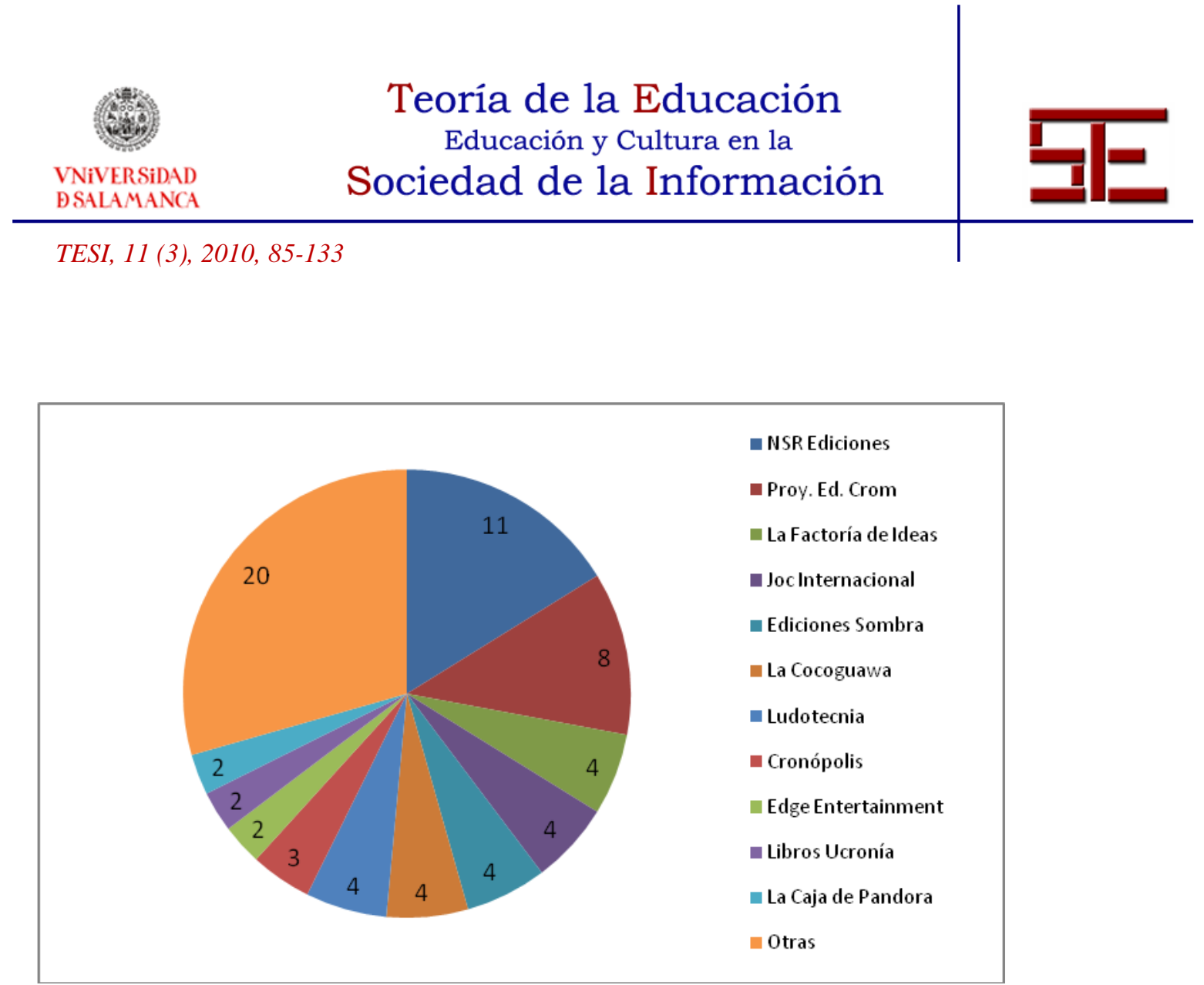

Figura 27. Distribución de editoriales de rol en España según el número de juegos autóctonos para los que han realizado publicaciones.

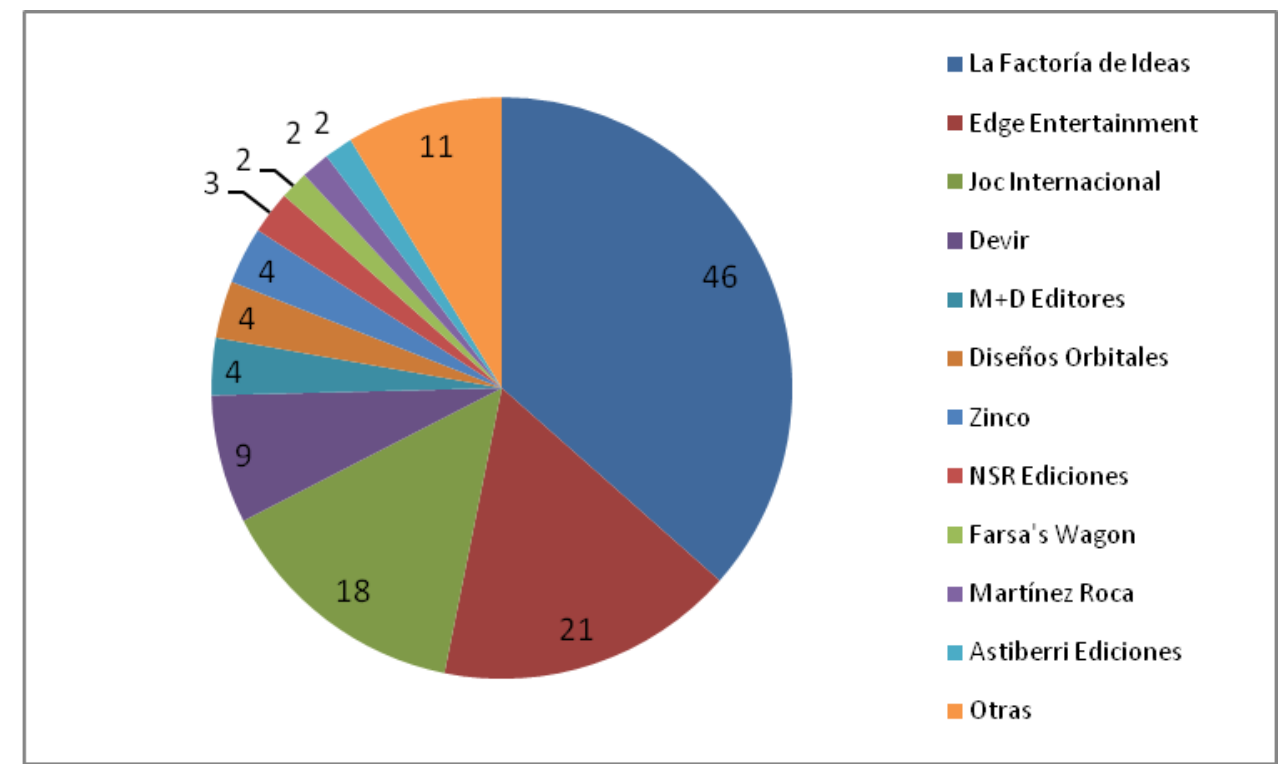

Figura 28. Distribución de editoriales de rol en España según el número de juegos no autóctonos para los que han realizado publicaciones.

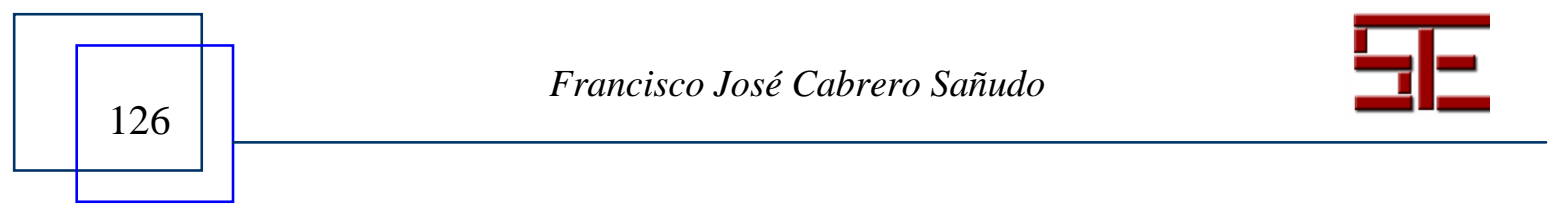



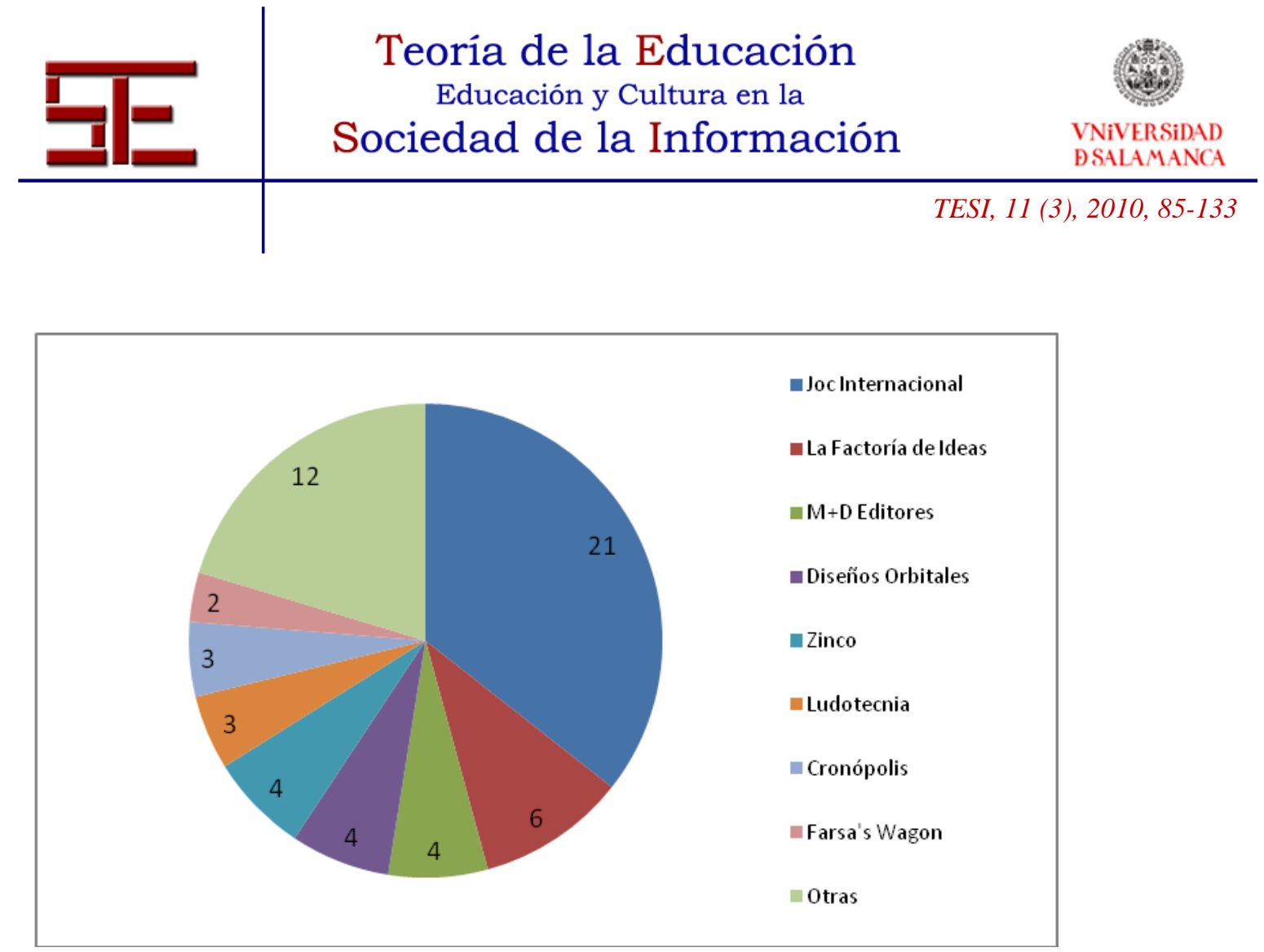

Figura 29. Distribución de editoriales de rol en España durante 1985-1996 según el número de juegos para los que han realizado publicaciones.

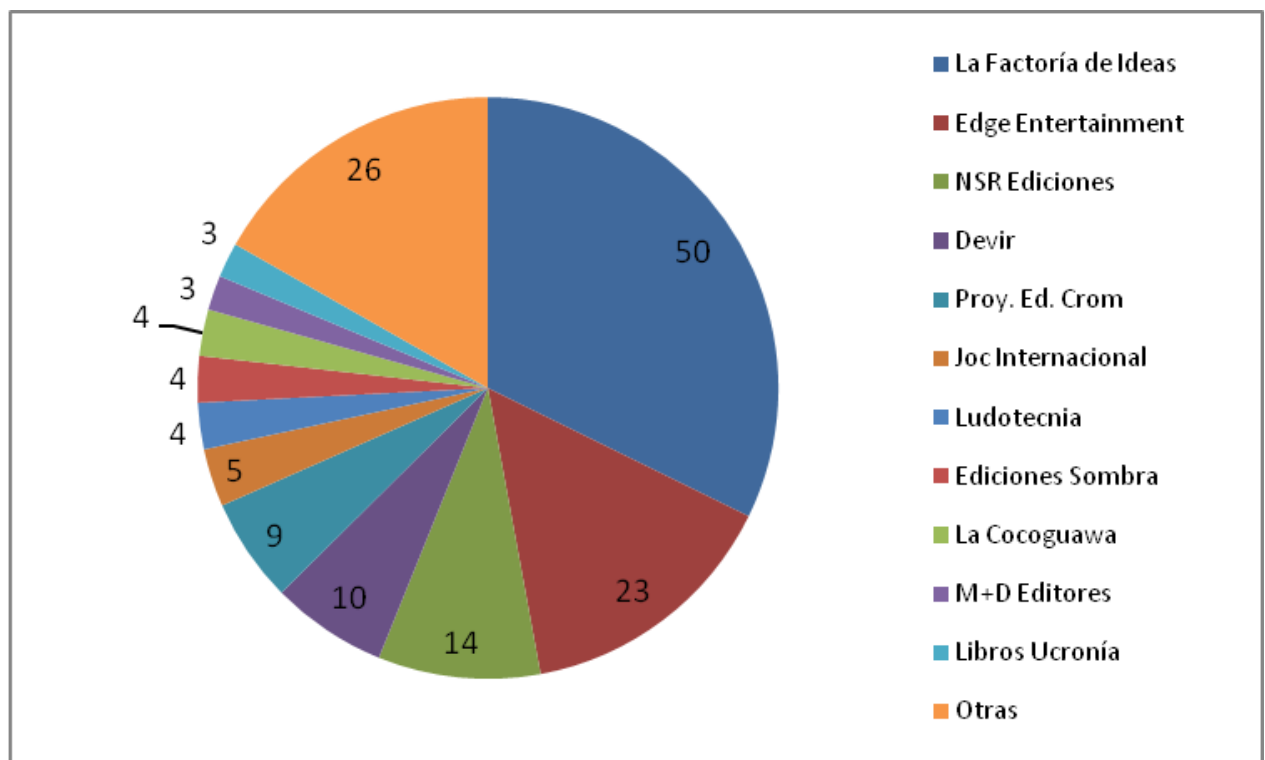

Figura 30. Distribución de editoriales de rol en España durante 1997-2008 según el número de juegos para los que han realizado publicaciones.

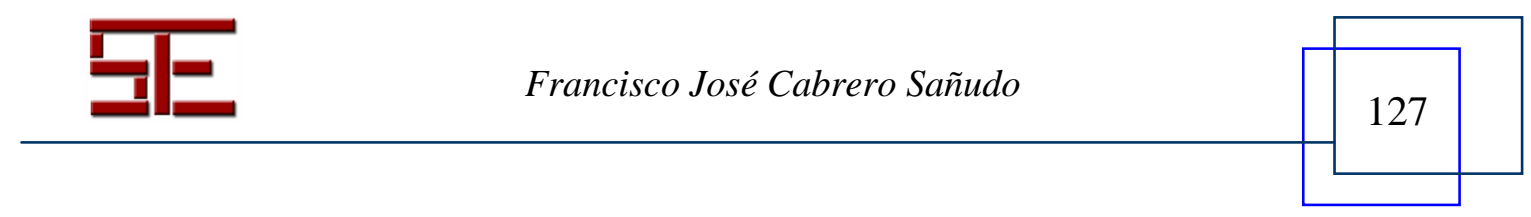



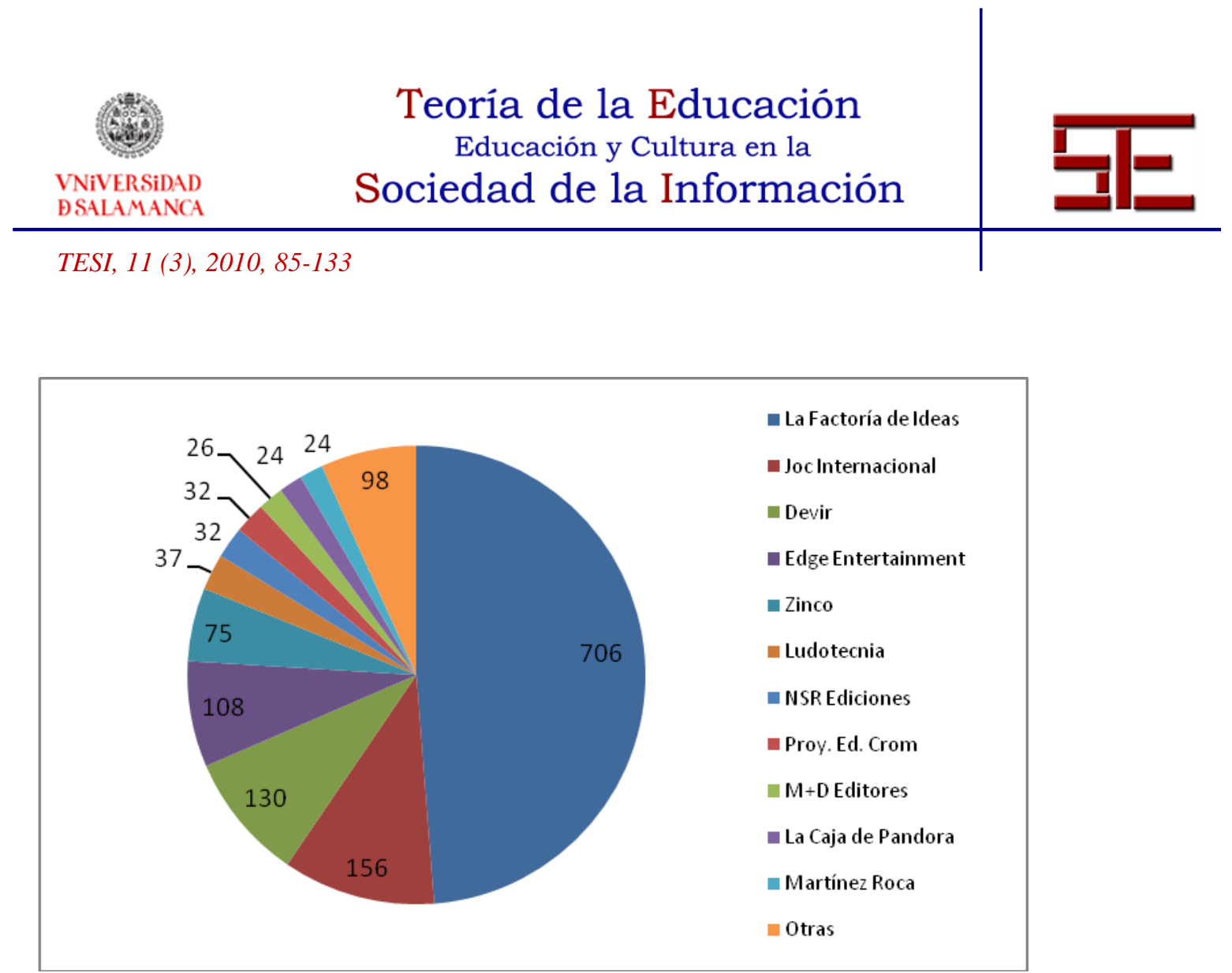

Figura 31. Distribución de editoriales de rol en España según el número de publicaciones.

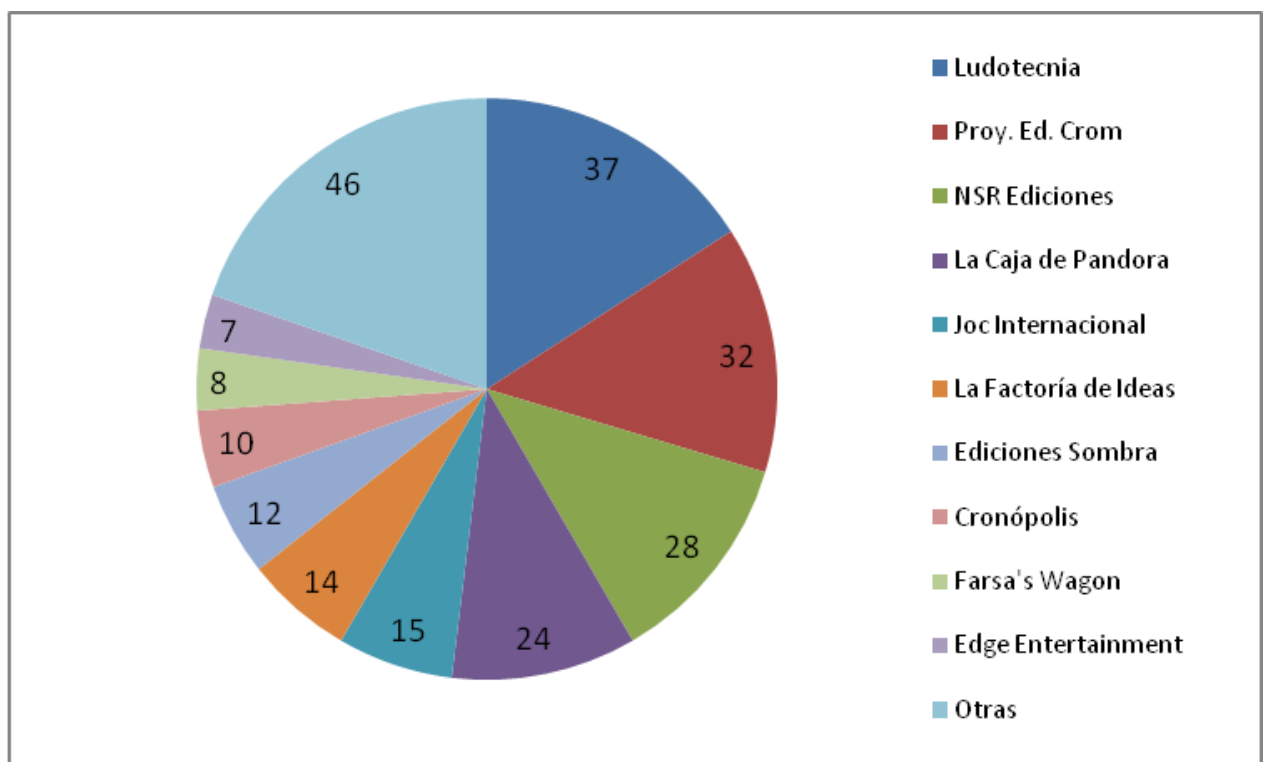

Figura 32. Distribución de editoriales de rol en España según el número de publicaciones autóctonas.

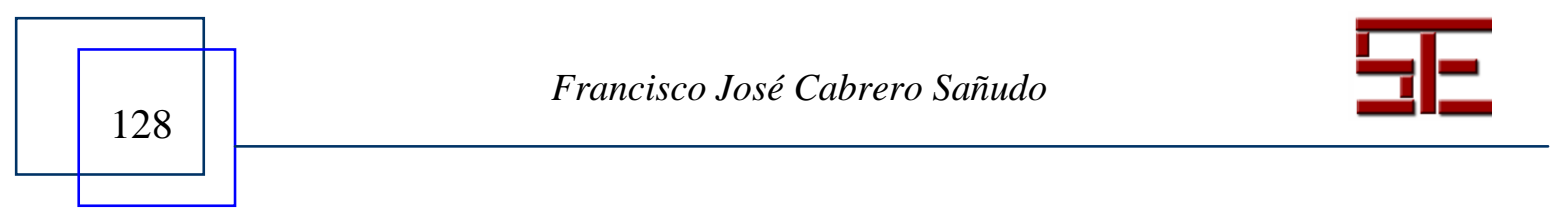



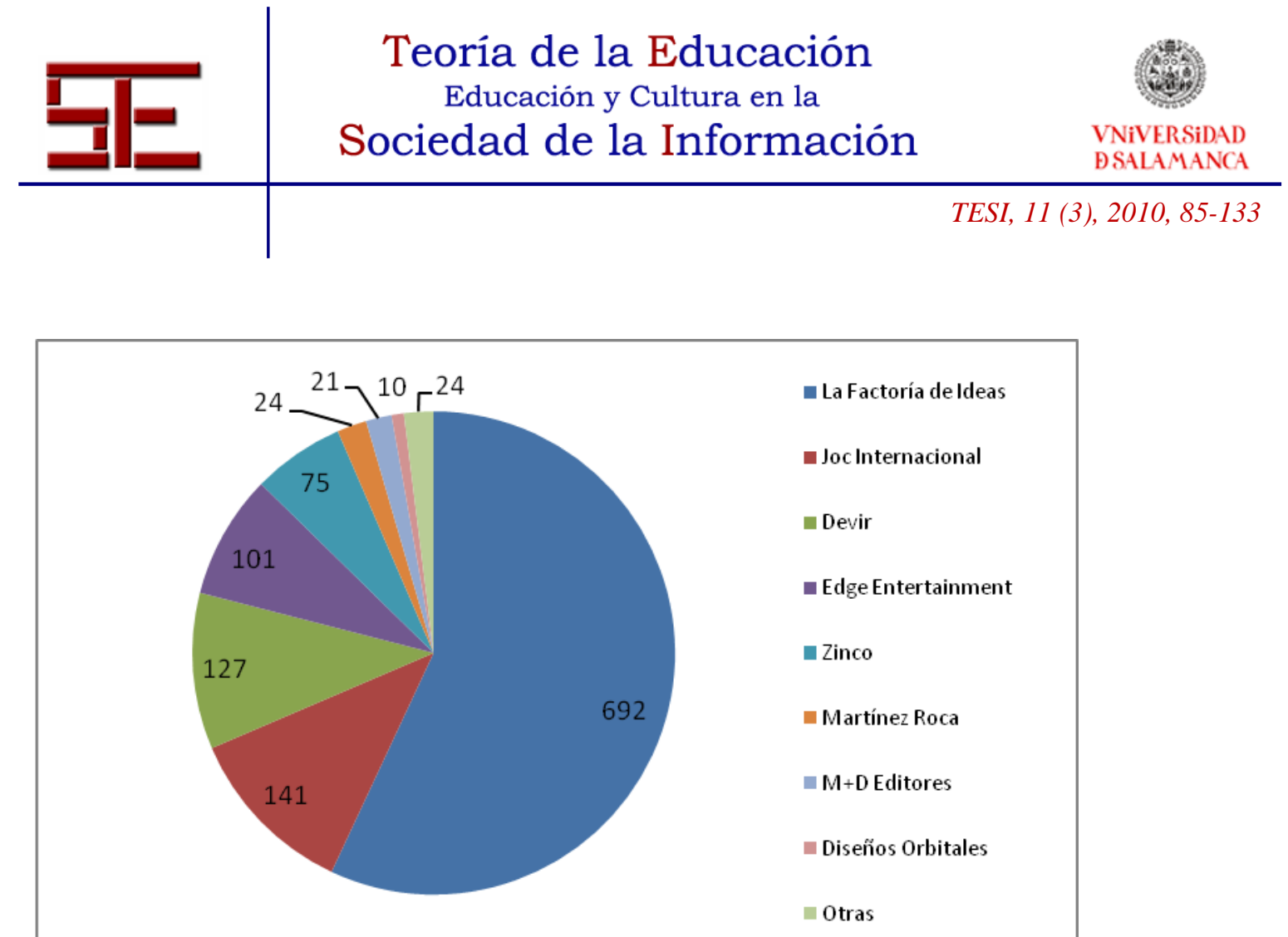

Figura 33. Distribución de editoriales de rol en España según el número de publicaciones no autóctonas.

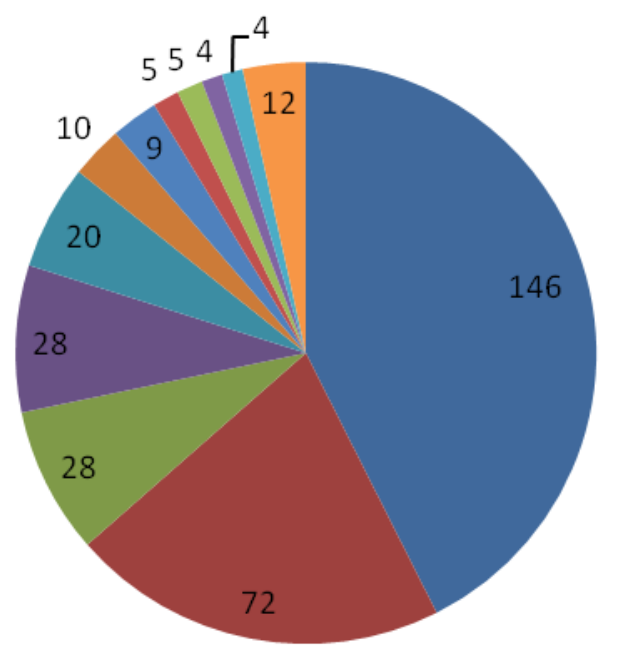

$$
\begin{aligned}
& \text { Joc Internacional } \\
& \text { Zinco } \\
& \text { La Factoría de Ideas } \\
& \text { Ludotecnia } \\
& \text { M+D Editores } \\
& \text { Diseños Orbitales } \\
& \text { Cronópolis } \\
& \text { Kerykion } \\
& \text { Farsa's Wagon } \\
& \text { Borrás } \\
& \text { Dalmau Carles, Pla } \\
& \text { E Otras }
\end{aligned}
$$

Figura 34. Distribución de editoriales de rol en España durante 1985-1996 según el número de publicaciones.

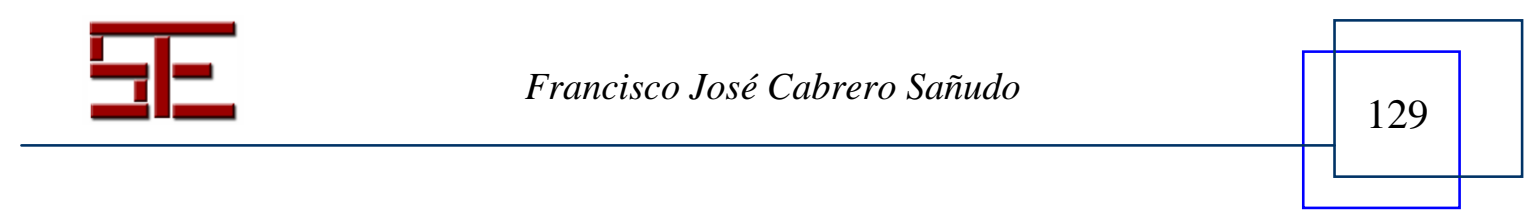



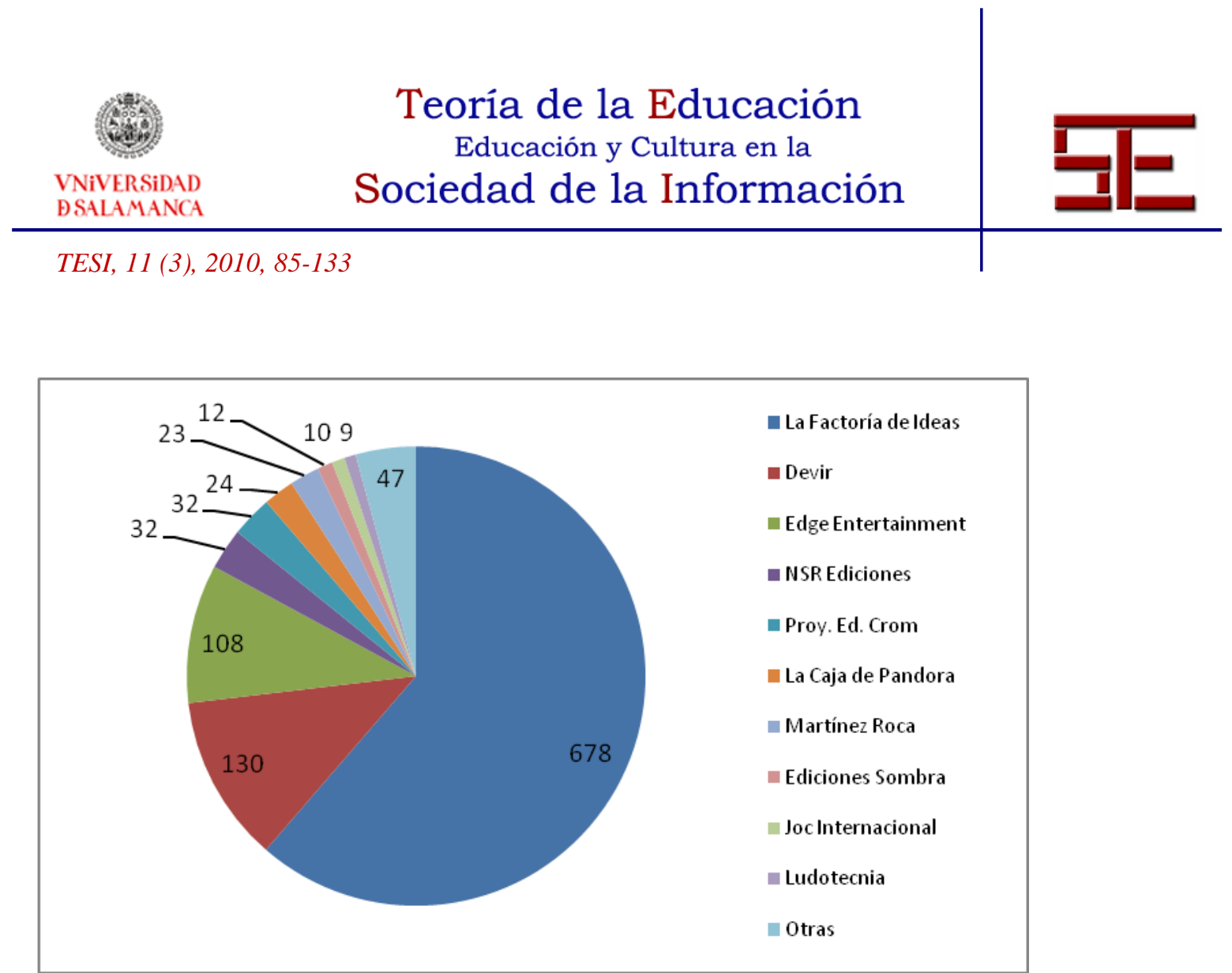

Figura 35. Distribución de editoriales de rol en España durante 1997-2008 según el número de publicaciones.

\section{5.- AGRADECIMIENTOS}

El autor quiere agradecer a todos aquellos lectores de la página de Utilidades-d20 (http://www.utilidades-d20.com/) que hubieran ayudado a corregir las erratas presentes en datos y análisis preliminares, así como contribuido a mejorar el presente artículo.

\section{6.- BIBLIOGRAFÍA.}

ALABORT, D. y POL, J. (2001): Fanpiro. Barcelona, La Factoría de Ideas/Fanhunter S.L.

BRIDGES, B.; CHILlOT, R.; CLIFFE, K. y LEE, M. (2004): Mundo de Tinieblas. Madrid, La Factoría de Ideas.

CHARLTON, C. (1989): El Señor de los Anillos. Barcelona, Joc Internacional.

COOK, D. (1992): Advanced Dungeons \& Dragons $2^{a}$ Edición. Manual del jugador. Barcelona, Ediciones Zinco.

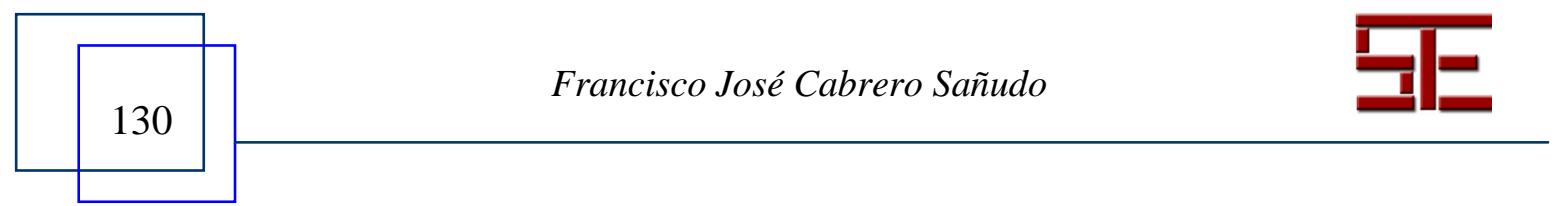




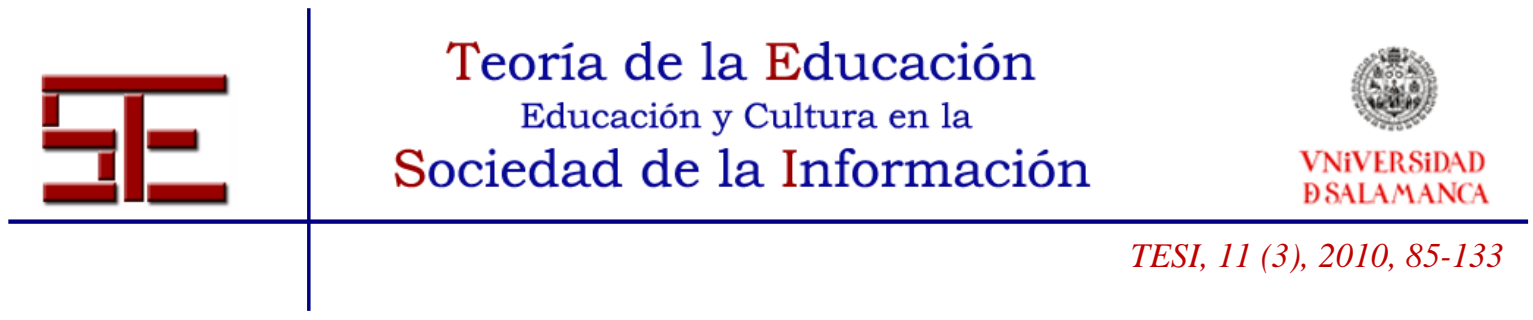

COOK, M.; TWEET, J. y WILLIAMS, S. (2001): Dungeons \& Dragons $3^{a}$ Edición. Manual del jugador. Barcelona, Devir S.L.

COOK, M.; TWEET, J. y WILLIAMS, S. (2003): Dungeons \& Dragons 3.5 Edición Manual del jugador. Barcelona, Devir S.L.

COSTIKYAN, G.; SMITH, C. y ROLSTON, K. (1990): Star Wars. Barcelona, Joc Internacional.

DOWD, T. (1993): Shadowrun. Barcelona, Diseños Orbitales.

EQUIPO DE DISEÑO DE LUDOTECNIA (1992): Ragnarok. Bilbao, Ludotecnia.

FERNÁNDEZ, P. y RODRíGUEZ, I. (2007): As crónicas de Gáidil. Ourense, Difusora de Letras, Artes e Ideas.

GARZÓN, F. y ARRIOLA, I. (1991): Mutantes en la sombra. Bilbao, Ludotecnia.

GRAU, E. (1995): Almogàvers. Barcelona, Joc Internacional.

GRAU, E. (1996): Tirant lo Blanc. Barcelona, Joc Internacional.

GYGAX, G. y ARNESON, D. (1974): Dungeons \& Dragons. Lake Geneva, WI, USA, Tactical Studies Rules.

GYGAX, G.; ARNESON, D. y MENTZER, F. (1985): Dungeons \& Dragons. Básico. Girona, Dalmau Carles Pla S.A.

HARTSHORN, J.; SKEMP, E.; REIN.HAGEN, M. y HASSALL, K. (1996): Vampiro, edad oscura. Madrid, La Factoría de Ideas.

HEINSOO, R.; COLliNS, A. y WYATT, J. (2008): Dungeons \& Dragons $4^{a}$ Edición Manual del jugador. Barcelona, Devir S.L.

HERREROS, J.C. (1990): Comandos de guerra. Madrid, Alas de Dragón.

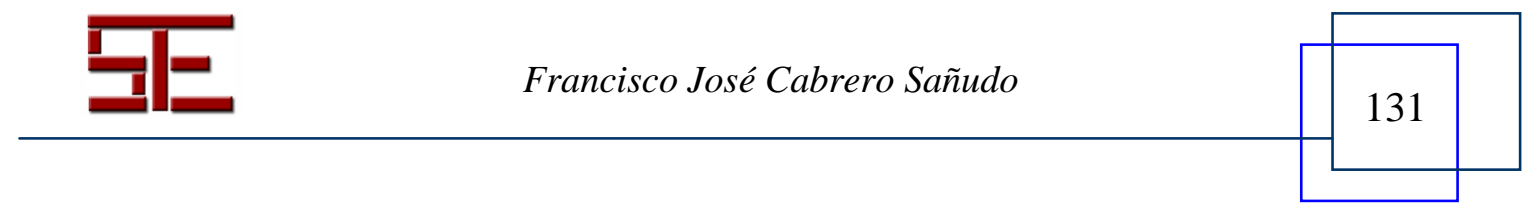


HERREROS, J.C.; LÓPEZ, R.; RUIZ-TAPIADOR, F.; SERRANO, H.W. y SEVILLA, J. (1999): Exo. Manises, Valencia, Ediciones Sombra.

IBÁÑEZ, R. (1990): Aquelarre. Barcelona, Joc Internacional.

LÓPEZ-HERRERO, R.; MEDINA, M. y ALCÁNTARA, M.A. (1994): Superhéroes Inc. Madrid, Cronópolis.

MATAS, A. (2008): Los juegos de rol, un acercamiento psicopedagógico. Málaga, publicado por el autor en Lulú/Ediciones Aidesoc.

MICROSOFT CORPORATION (2007): Microsoft Office 2007. Redmond, WA, USA, Publicado por la compañía.

MILLER, M.W. (1989): Traveller. Barcelona, Diseños Orbitales.

MUÑOZ, A.; PAREDES, A.; DÍEZ, R.; SANTOS, J.; MAGALLANES, M.; BOLAÑOS, N.; ESTUPIÑA, F.J. y RAMOS, P.J. (2006): Tras la pantalla. Madrid, Nosolorol Ediciones.

O’SULLIVAN, S. (1995): Fudge. Randolph, MA, USA, Grey Ghost Press Inc. Juego de licencia libre disponible en: http://www.fudgerpg.com/files/pdf/fudge_1995.pdf

PAMUNDI, C.; GARRIGA, X. y PIÑOL, C. (1992): Fanhunter. Barcelona, Farsa's Wagon.

PETERSEN, S. (1988): La llamada de Cthulhu. Barcelona, Joc Internacional.

PONDSMITH, M. (1993): Cyberpunk 2.0.2.0. Madrid, M+D Editores S.L.

REIN.HAGEN, M. (1993): Vampiro, la mascarada. Barcelona, Diseños Orbitales.

REIN.HAGEN, M. (1995): Hombre lobo, el apocalipsis. Madrid, La Factoría de Ideas.

ROMERO-SALAZAR, J.A. (1994): Piratas!! Bilbao, Ludotecnia.

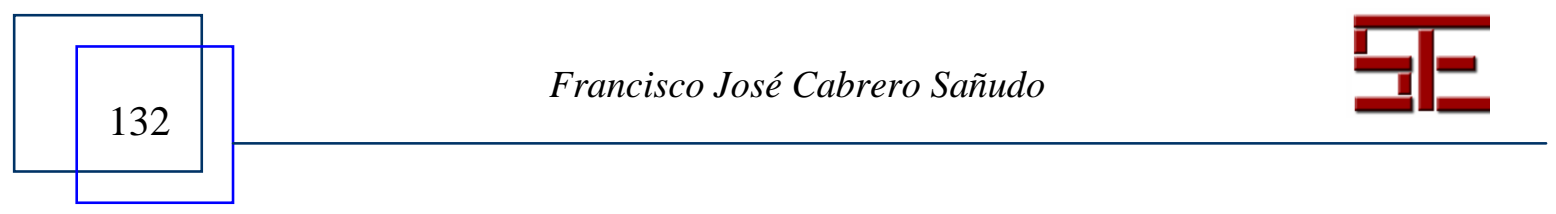




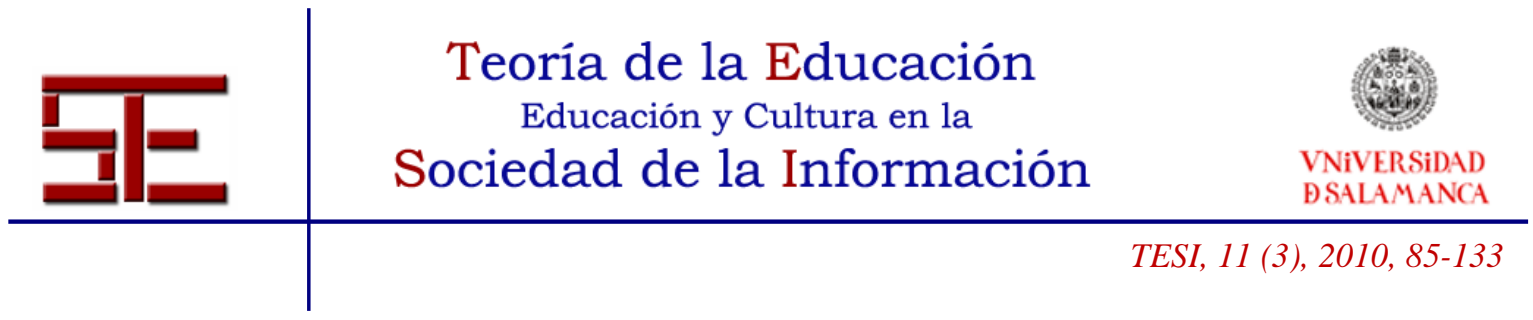

SÁNCHEZ, D. (2007): Juegos de rol: mito y realidad. Publicado on-line en: http://dreamers.com/defensadelrol/articulos/Juegos_de_rol__Mito_y_realidad.pdf.

Web para la Defensa de los Juegos de Rol.

SCHMIDT, V.L. (2005): Story structure architect. Georgetown, ON, Canada, Writer's Digest Books.

STAFFORD, G. (1988): RuneQuest. Barcelona, Joc Internacional.

STATSOFT INC. (2006): STATISTICA (data analysis software system), version 7.1. Tulsa, USA, Publicado por la compañía.

TIZÓN, R. (2007): Creer lo increíble. Madrid, Nosolorol Ediciones.

TWEET, J. y REIN.HAGEN, M. (1993): Ars magica. El arte de la magia. Palma de Mallorca, Kerykion.

WICK, J. (1998): La leyenda de los 5 anillos. Madrid, La Factoría de Ideas.

WICK, J.; WICK, J. y WILSON, K. (2000): $7^{\circ}$ Mar, Guía del jugador. Madrid, La Factoría de Ideas.

WIECK, S.; EARLEY, C.; WIECK, S.; BRIDGES, B.; CHUPP, S. y GREENBERG, A. (1996): Mago, la ascension. Madrid, La Factoría de Ideas.

WIZARDS OF THE COAST INC. (2000): System Reference Document. Renton, WA, USA. Versión revisada $3.5^{\mathrm{a}}$ edición publicada por la compañía en: http://www.wizards.com/default.asp? $\mathrm{x}=\mathrm{d} 20 /$ article/srd35.

WIZARDS OF THE COAST INC. (2008): The Dungeons \& Dragons $4^{\text {th }}$ edition game system license. Renton, WA, USA. Versión revisada $4^{\text {a }}$ edición publicada por la compañía en: http://www.wizards.com/default.asp?x=d20/welcome.

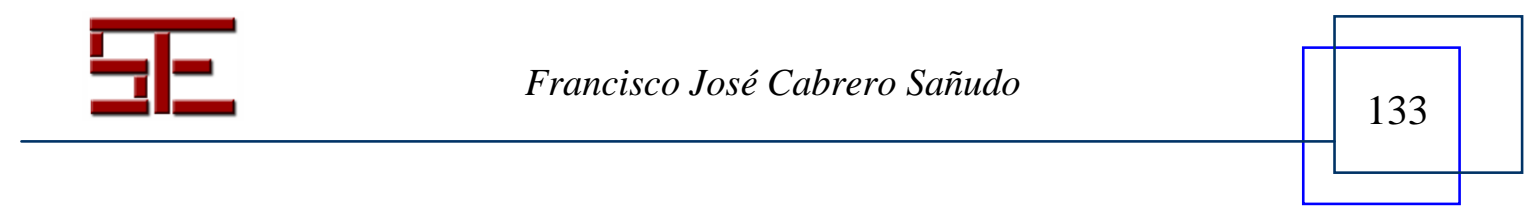


Para citar el presente artículo puede utilizar la siguiente referencia:

Cabrero Sañudo, F.J. (2010). Historia de las publicaciones de los juegos de rol en españa, en Orejudo González, J.P. (Coord.) Perspectiva educativa y cultural de "juego de rol". Revista Teoría de la Educación: Educación y Cultura en la Sociedad de la Información. Vol. 11, no 3. Universidad de Salamanca, pp. 85-133 [Fecha de consulta: $\mathrm{dd} / \mathrm{mm} / \mathrm{aaaa}]$.

http://campus.usal.es/ revistas_trabajo/index.php/revistatesi/article/view/7451/7467 